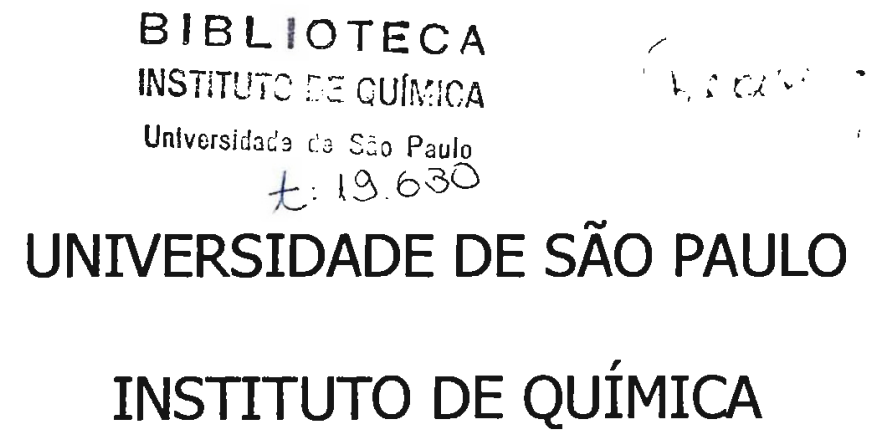

\title{
MODULAÇÃO DO ESTRESSE OXIDATIVO EM GLÂNDULAS SUBMANDIBULARES DE RATO
}

\author{
ALCELY STRUTZ BARROSO
}

TESE DE DOUTORADO

Orientador: Prof. Dr. Pio Colepicolo

SÃo PAULO

$06 / 07 / 2001$ 


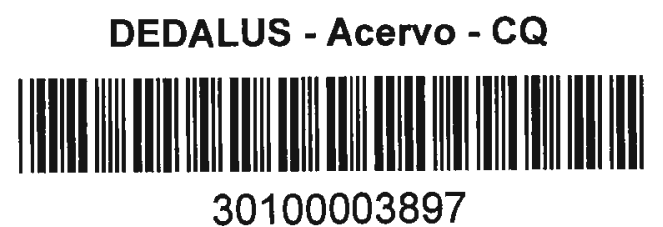

Ficha Catalográfica

Elaborada pela Divisão de Biblioteca e

Documentação do Conjunto das Químicas da USP.

Barroso, Alcely Strutz
B277m Modulação do estresse oxidativo em glândulas submandibulares de rato / Alcely Strutz Barroso. -- São Paulo, 2001.

$119 \mathrm{p}$

Tese (doutorado) - Instituto de Química da Universidade de São Paulo. Departamento de Bioquímica.

Orientador: Colepicolo, Pio

1. Bioquímica 2. Estresse oxidativo: Medicina I. T. 11. Colepicolo, Pio, orientador. 


\section{"Modulação do Estresse Oxidativo em Glândulas Submandibulares de Rato"}

\section{ALCELY STRUTZ BARROSO}

Tese de Doutorado submetida ao Instituto de Química da Universidade de São Paulo como parte dos requisitos necessários à obtenção do grau de Doutor em Ciências - Área: Bioquímica.

Aprovada por:

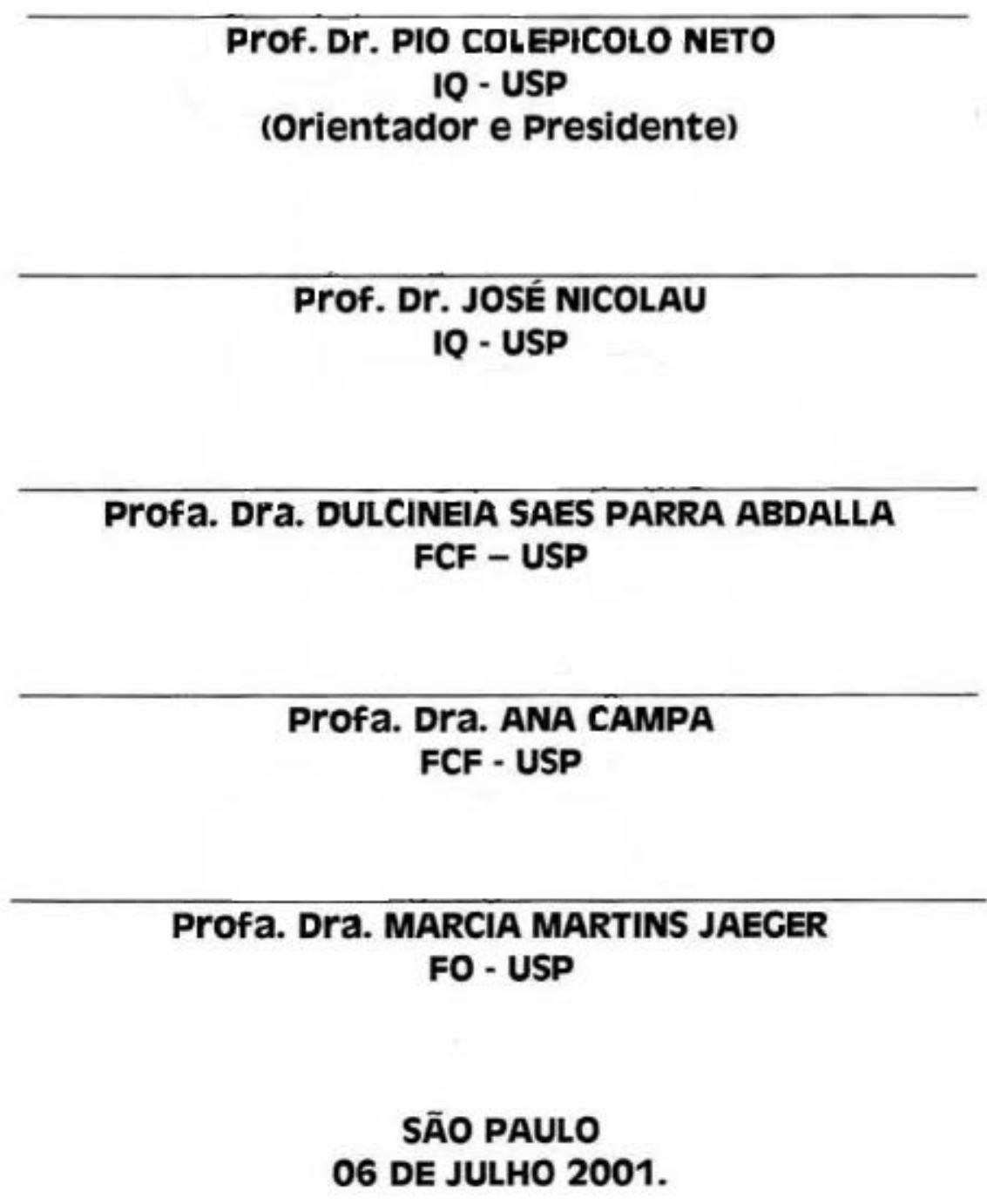




\section{ALCELY STRUTZ BARROSO}

Tese de doutorado submetida ao Instituto de Química da Universidade de São Paulo como parte dos requisitos necessários à obtenção do grau de Doutor em Ciências - Área: Bioquímica.

São Paulo 
Ao meu marido Sergio pelo afeto, pela compreensão e ajuda em todas as fases de realização deste trabalho.

Ao meu querido filho Rodrigo por chegar na hora certa e me trazer uma nova visão sobre a vida. 
Aos meus pais, Celso e Eclair, pelo incentivo e apoio em todas as etapas de meus estudos.

À minha irmã Cibeli pelo companheirismo e pela amizade.

Aos meus sogros Sergio e Ana Flora e aos meus cunhados Luciana e Guillermo pelo apoio em todos os momentos.

À minha família por compreender minha ausência em vários momentos. 


\section{AGRADECIMENTOS}

Ao meu orientador, Dr. Pio Colepicolo, pelo incentivo e pela dedicação que demonstrou durante todo o período do tłabalho. Sua ampla visão sobre a ciência foi essencial para meu desenvolvimento profissional e permitiu o seguimento desta linha de pesquisa.

Ao Dr. David O. Quissell pela amizade e por disponibilizar gentilmente seu laboratório em algumas etapas do trabalho

Às técnicas Lynn M. Deisher e Katherine Barzen por me treinarem na preparação da cultura de células dispersas.

Ao Dr. José Nicolau por ser meu primeiro incentivador ao estudo científico e principalmente me mostrar a importância desta linha de pesquisa.

Ao Ednailson pela amizade e pelo grande auxílio durante os experimentos com animais e por estar sempre presente em momentos indispensáveis da realização desta Tese.

À amiga Márcia Vieira da Motta pela compreensão e ajuda em todos os momentos e por permitir que pudesse fazer novas escolhas em minha carreira.

À amiga Marinez pela amizade e por poder contar com a ajuda, o apoio e compreensão em momentos importantes de desenvolvimento da Tese.

À amiga Patrícia pela ajuda incansável no laboratório e pelas agradáveis conversas durante todo o nosso período no laboratório. 
Ao Ernani pela grande amizade e pelos momentos divertidos que passamos durante este período.

Ao amigo Keith pela ajuda com os ensaios de medida de estresse oxidativo e pelo seu grande interesse e disposição prestados.

Aos amigos Léo, Fernando, Heloísa, Teresa, Marcelo, Valdemir, Antonieta, Karina, Vanessa, Fabiana pelo apoio e amizade.

À Sandra por manter o laboratório em condições e pela disposição para ajudar.

Ao Pio Zapela, Rosângela, Marli e Alexandre pela contínua amizade e pela preocupação mesmo estando longe.

Aos amigos Zeca, Sandra, Rafael, Rafaela e Mateus por me apoiarem sempre.

Aos funcionários da secretaria de pós-graduação pela dedicação e pela boa vontade na realização dos serviços prestados.

Ao IQ-USP por permitir que este trabalho fosse realizado em excelentes condições.

Ao CNPq pelo auxílio financeiro nas etapas iniciais deste trabalho.

À FAPESP pelo apoio financeiro indispensável para o desenvolvimento científico.

Ao Departamento de Biologia Craniofacial da Universidade do Colorado em Denver (EUA). 


\section{Índice}

1.1. SALIVA: COMPOSIÇÃo E FUNÇÃo

1.2. ESTRUTURA DAS GLÂNDULAS SALIVARES

1.3. REGULAÇão FISIOLÓGICA DE SECREÇÃo SALIVAR

1.4. ESTÍMULO ADRENÉRGICO E COLINÉRGICO 11

1.4.1. EXOCITOSE E SIALADENOSE 11

1.4.2. SECREÇÃO FLUIDA

1.5. ESPÉCIES REATIVAS DE OXIGÊNIO E SUAS IMPLICAÇõES BIOLÓGICAS 14

$\begin{array}{ll}\text { 1.6. SISTEMAS ANTIOXIDANTES } & 17\end{array}$ 
$\begin{array}{ll}\text { 3.2. ANIMAIS } & 23\end{array}$

3.3. INJEÇÕES

3.3.1. Tratamento COM ISOPROTERENOL (ISO), CARbacol (CA) OU

- CICLOHEXIMIDA (CHX) 23

3.4.2. PRÉ-TRATAMENTO COM CHX SEGUIDO DE TRATAMENTO COM ISO 24

3.3.3. PREPARAÇÃO DO EXTRATO TOTAL E DETERMINAÇÃO DE PROTÉ́NAS 24

3.4. CULTURA DE CÉlULAS DisPersas 25

3.4.1. PROCEDIMENTO DE ISOLAMENTO DAS CÉLULAS ACINARES

3.5. ENSAIOS IN VITRO

3.5.1. AÇÃo DE ISO, CHX, CA E PROPaNOLOL (PROP) EM CÉlULAS ACINARES 28

3.5.2. CONTROLE DA ATTVIDADE DE SOD NO EXTRATO SOB AÇ̃̃O DE ISO, CHX E CA. 29

$\begin{array}{ll}\text { 3.6. ATIVIDADE ANTIOXIDANTE } & 30\end{array}$

$\begin{array}{ll}\text { 3.6.1. ATIVIDADE DE SOD } & 30\end{array}$

3.6.2. DETERMINAÇÃO DOS NIVEIS PROTÉICOS DE SOD E ANÁLISE POR "WESTERN BLOT" $\quad 30$

3.7. DETERMINAÇ̃̃o DE ESTRESSE OXIDATIVO 32

3.7.1. PODER REDUTOR 32

3.8. DETERMINAÇÃO DE LESÕES OXIDATIVAS 32

3.8.1. MEDIA DA PRODUÇÃO DE MDA 32

3.8.2. OXIDAÇão PROTÉICA 33

3.9. ANÁLISE ESTATÍSTICA

4. RESULTADOS 34

4.1. NÍVEIS DE MDA PRODUZIDOS IN VIVO. 34 
4.2. NÍVEIS DE MDA PRODUZIDOS POR TRATAMENTOS EM CULTURA DE CÉLULAS DISPERSAS.

4.3. OXIDAÇÃO DE PROTEÍNAS IN VIVO. 43

4.4. OXIDAÇÃo dE PROTEÍNAS EM CÉLULAS DISPERSAS. 44

4.5. PODER REDUTOR APÓS TRATAMENTOS IN VIVO. 51

4.6. PADRÃo de ATIVIDADE TOTAL DE SOD EM TRATAMENTOS IN VIVO. 58

4.7. DETECÇÃO DE ISOFORMAS DE SOD POR "WESTERN BLOT". 67

4.8. PAdRÃo de ATIVIDAde TOTAL DE SOD EM CÉlULAS DISPERSAS. 70

5. DISCUSSÃO 76 


\section{RESUMO}

As espécies reativas de oxigênio geradas in vivo têm sido implicadas em vários mecanismos como apoptose, crescimento e diferenciação celular, câncer e inflamação. O estresse oxidativo é o produto do desbalanço entre os agentes prooxidantes e antioxidantes celulares, causando danos por meio da peroxidação lipídica, oxidação de proteínas e de DNA. Neste trabalho avaliou-se o efeito do estresse oxidativo em glândulas submandibulares de rato e em células acinares dispersas tratadas com isoproterenol (ISO), cicloheximida (CHX), carbacol (CA) e propanolol (PROP). Observou-se aumento dos níveis de MDA em homogenados de glândulas de ratos tratados com ISO e $\mathrm{CHX}$ e em células acinares dispersas incubadas com ISO e $\mathrm{CHX}$. Tratamentos semelhantes causaram aumento na oxidação protéica em cultura de células, mas o mesmo aumento não ocorreu in vivo. Em relação aos agentes antioxidantes, observou-se um aumento no poder redutor (conteúdo de GSH) em homogenados de glândulas submandibulares tratadas com ISO e em células dispersas incubadas com ISO. A atividade de superóxido dismutase (SOD) também aumentou em tratamentos com ISO in vivo e os "Western Blots" mostraram uma variação acentuada nos níveis protéicos da isoforma MnSOD. A atividade de SOD, induzida por ISO em células dispersas, não ocorre quando as células foram pré-incubadas com PROP, o que sugere a ativação da atividade de SOD via receptores $\beta$-adrenérgicos. 


\section{ABSTRACT}

Reactive oxygen species (ROS) have been implicated in many mechanisms as apoptosis, cell growth and differentiation, cancer and inflammation. Oxidative stress is the product of the imbalance of the prooxidants and antioxidants agents within the cell and it has been shown to cause damage by producing peroxidation of fatty acid and oxidation of proteins and DNA. In this work the oxidative stress was evaluated on rat submandibular glands and on dispersed acinar cells treated with isoproterenol (ISO), cycloheximide (CHX), carbachol (CA) and propanolol (PROP). The level of lipid

peroxidation on rats submandibular glands and on dispersed acinar cells were increased by ISO and $\mathrm{CHX}$ treatment. Protein oxidation level was increased on cell culture treated with ISO, but the same results was not found in vivo treatments. Regards the antioxidant agents, the GSH content was found to increase on both in vivo and on cell culture by ISO treatment. The superoxide dismutase (SOD) activity in vivo increased and the Western Blots showed a significant MnSOD variation level. The SOD was induced by ISO treatment on cell culture, but the same increasing was not found with previous cells treatment with PROP. This result suggest the involvement of a $\beta$-adrenergic receptor on SOD activity. 


\section{ABREVIATURAS, NOTAÇÃO E NOMENCLATURAS}

Ab SOD: anticorpo policlonal contra superóxido dismutase

BSA: albumina de soro bovina

CA: carbacol

cAMP: 3', 5'-monofosfato cíclico de adenosina

CAT: catalase

CDK: proteína quinase dependente de ciclina

CHX: cicloheximida

cit. c: citocromo c

DAG: diacilglicerol

DME: Dulbecco's Modified Eagle

D.O.: densidade óptica

DTNB: 5,5'-ditiobis-2-ácido nitrobenzóico

DTT: ditiotreitol

EDTA: ácido etileno diamino tetra acético

EGF: fator de crescimento epidermal

ERO: espécies reativas de oxigênio

GPx: glutationa peroxidase

GR: glutationa redutase

GSH: glutationa reduzida

GSSG: glutationa oxidada

$\mathrm{IP}_{3}$ : inositol trifosfato

ISO: isoproterenol 
MDA: malondialdeído

PAGE: eletroforese em gel de poliacrilamida

PBS: tampão fosfato salino

PIP $_{2}$ : fosfatidil inosito bifosfato

PKA: Proteína quinase $A$

PROP: Propanolol

PVDF: difluoreto de polivinilidina

SDS: dodecil sulfato de sódio

SOD: superóxido dismutase

SS: síndrome de Sjögren

TCA: ácido tricloroacético

TEMED: $N, N_{,} N^{\prime}, N^{\prime}$, tetra metil etileno diamina

Tris: tris (hidroxi metil) amino metano

u.a.: unidades arbitrárias 


\section{Introdução}

\subsection{Saliva: composição e função}

A saliva é um fluido extremamente complexo, responsável pela integridade dos tecidos bucais. A saliva atuante na cavidade bucal é chamada de saliva total. Ela é uma mistura composta das secreções produzidas pelas três glândulas salivares maiores (parótida, submandibular e sublingual), pelas glândulas salivares menores localizadas na mucosa bucal e pelo fluido gengival. Nesta mistura ainda podem ser encontradas células epiteliais descamadas, células do sistema imune tais como neutrófilos e macrófagos e microorganismos que habitam a cavidade bucal (Edgar, 1992).

Noventa por cento da saliva total diária é proveniente da secreção das glândulas parótidas e submandibulares, cerca de cinco por cento das glândulas sublinguais e cerca de cinco a dez por cento das glândulas salivares menores. A saliva total produzida diariamente é de aproximadamente 0,5 a 1 litro num fluxo que pode variar de $0,02 \mathrm{~mL} / \mathrm{min}$ sem estímulo a $1 \mathrm{~mL} / \mathrm{min}$ quando estimulada (Levine, 1989).

A função da saliva é proteger a mucosa e os dentes, facilitar a fala, a mastigação e a deglutição e agir como barreira antimicrobiana e antifúngica. Suas propriedades de alta viscosidade, elasticidade e adesividade the permitem manter a integridade da mucosa bucal agindo como uma barreira efetiva contra o seu ressecamento. O fluxo salivar também funciona como agente na remoção mecânica das bactérias superfícies mucosas, impedindo a proliferação excessiva destes 
microorganismos. A remoção mecânica dos microorganismos é especialmente importante nos casos de fluxo salivar reduzido (Mandel, 1987; Edgard et al., 1994).

A saliva é composta de água, íons inorgânicos e materiais orgânicos. Seu pH varia de 6,7 a 7,4. Os principais íons inorgânicos são sódio, potássio, cloro, bicarbonato, cálcio, magnésio, iodo, tiocianato e flúor (Levine, 1989). Sua porção orgânica é composta de carboidratos, lipídios, proteínas e glicoproteínas. A maior parte dos carboidratos está associada a proteínas, atuando no aumento da viscosidade da saliva (Levine et al., 1987). Os lipídios encontram-se na forma de ácidos graxos, colesterol e fosfolipídios. Demonstrou-se que a sua quantidade está associada à resistência à cárie, sendo que a secreção de lipídios está sob controle adrenérgico (Slomiany et al., 1982; Slomiany et al., 1989; Larsson et al. 1996; Slomiany et al., 1992).

A composição salivar varia com seu fluxo secretório. Um aumento no fluxo salivar revela uma elevação na concentração dos íons sódio, cloro, bicarbonato e de proteínas e leva a uma diminuição nos níveis dos íons magnésio e fosfato, mas sem alteração nos níveis de potássio. Os estímulos gustativos também podem aumentar o fluxo salivar em até dez vezes, sendo o estímulo ácido o mais efetivo (Edgar, 1992; Dawes, 1984). O ritmo circadiano também exerce um efeito na variação individual de componentes da saliva. No mesmo dia os níveis de cálcio e fosfato medidos na saliva total não estimulada podem ter variações marcantes (Larsen et al., 1999).

$\mathrm{Na}$ saliva encontram-se as proteínas $\alpha$-amilase, mucina, estaterina, calmodulina, histatina, lisozima, lactoferrina, peroxidase salivar, imunoglobulinas e 
proteínas ricas em prolina (PRPs). Estas proteínas com efeitos diversos agem na manutenção da saúde bucal (Edgar, 1992; Hay \& Moreno, 1989).

A $\alpha$-amilase é uma enzima digestiva secretada predominantemente pela glândula parótida. A enzima tem a capacidade de hidrolisar cadeias polissacarídicas do amido. Acredita-se que na cavidade bucal ela exerça esta função apenas em locais de retenção alimentar (Mandel, 1987).

As glicoproteínas salivares têm um papel muito importante na proteção nãoimune da cavidade bucal, auxiliando na lubrificação e na mastigação. As mucinas fazem parte desta classe de glicoproteínas produzidas principalmente pelas glândulas submandibulares e sublinguais (Tabak et al., 1982; Hatton et al., 1985). Recentemente demonstrou-se que as mucinas representam $16 \%$ do total de proteínas presentes na saliva total, desempenhando um importante papel na lubrificação da cavidade bucal (Rayment et al., 2000, Tabak et al., 1985).

As GRPs (glicoproteínas ricas em prolinas), as PRPs (proteínas ricas em prolina) e as estaterinas têm afinidade por cálcio. Estas proteínas, ligando-se ao cálcio, inibem a precipitação destes íons nas glândulas salivares, no meio bucal e na superfície dos dentes, uma vez que a saliva é supersaturada de íons cálcio e fosfato. (Bennick et al., 1981; Bennick, 1982; Hay et al., 1984).

A lisozima, a lactoferrina e a peroxidase salivar são proteínas com função antibacteriana, mantendo o equilíbrio microbiológico na saliva impedindo assim a proliferação bacteriana exacerbada (Levine, 1989).

As histatinas são proteínas encontradas em grânulos de secreção de glândulas parótidas, submandibular e sublingual assim como em sua secreção (Oppenheim et 
al., 1988; Takano et al. 1993; Johnson et al., 2000). Demonstrou-se possuírem ação antifúngica, sendo ativa contra diferentes espécies de Candida. O aumento dos níveis salivares das histatinas é observado em associação à candidíase bucal, cujo agente etiológico é a Candida albicans (Pollock, 1984; Bercier, 1999). Demonstrou-se que a concentração de histatinas diminui com o avanço da idade e com a utilização de bloqueadores $\beta$-adrenérgicos, apresentando uma importância clínica, pois leva a um aumento do risco de infecções por Candida (Johnson et al., 2000).

A infecção por Candida albicans pode ser causada por diminuição ou mesmo ausência do fluxo salivar, conhecida por xerostomia, e afeta o equilíbrio do ambiente bucal. Outros fatores sistêmicos e locais levam à predisposição para candidíase, incluindo a radioterapia de cabeça e pescoço, a quimioterapia, a infecção por HIV e diabetes. A infecção bucal associada à candidíase provoca ardência da região e despapilação da língua gerando um grande desconforto à pessoa (Lynch, 1994; Mandel et al., 1992; Jorge et al., 1993; Rossie et al., 1987).

Estudos relatam que em mais de $60 \%$ dos pacientes que desenvolveram candidíase decorrente da xerostomia apresentam as manifestações clínicas como ulcerações, vermelhidão e atrofia da mucosa bucal e das papilas linguais. Estes pacientes apresentam perda de apetite, dificuldade em deglutir e freqüentemente são portadores das chamadas cáries rampantes, que destroem com muita rapidez a maioria dos dentes. Estes sinais e sintomas causam um grande desconforto, reduzindo a qualidade de vida do indivíduo portador da doença (Fox, 1987; Levine et al., 1989; Mandel, 1987; Lynch, 1994). 
A xerostomia (ausência de saliva) também pode ser causada por radioterapia em tumores de cabeça e pescoço e por quimioterapia. Estas, dependendo da dose, podem levar a xerostomia temporária ou permanente (Stephens et al., 1986; Fox et al., 1987). A primeira resposta local observada após tratamentos de quimioterapia e radioterapia é a atrofia das glândulas sem a presença de inflamação, como resultado do mecanismo de apoptose. Após a irradiação observa-se que a principal alteração é a morte das células acinares, altamente especializadas. O grau de destruição das células glandulares irá determinar o grau de diminuição de fluxo salivar observado (Stephens, 1989).

A xerostomia pode também resultar de uma patologia conhecida como Síndrome de Sjögren (SS), causada por um distúrbio auto-imune crônico. A SS caracteriza-se por apresentar um infiltrado inflamatório. A manifestação primária da doença é a ausência de saliva (xerostomia) e lágrima (xeroftalmia). A manifestação secundária está associada a doenças como artrite reumatóide, lupus eritematoso sistêmico e esclerose sistêmica progressiva. A prevalência da SS nos EUA é alta, afetando mais de um milhão de pacientes, principalmente mulheres de meia idade. Estudos mostram que a incidência desta patologia é semelhante a da artrite reumatóide, que afeta de 1 a 3\% da população mundial (Scully, 1986; Strickland et al., 1985). Sendo provocadora de xerostomia, esta síndrome também pode facilitar o aparecimento de candidíase (Abraham et al., 1998).

Deste modo, a saliva é fundamental para manter o equilíbrio bucal e as glândulas salivares são as responsáveis pela constância desta secreção. Dentre as 
glândulas salivares, as glândulas submandibulares são as responsáveis por $70 \%$ da secreção diária e por isso o estudo da sua fisiologia é muito importante.

\subsection{Estrutura das glândulas salivares}

As glândulas salivares são exócrinas e têm uma estrutura composta de ductos terminados por estruturas secretoras de fundo cego chamadas ácinos. O ducto excretor principal divide-se em ductos progressivamente menores chamados ductos estriados. Estes se subdividem em ductos ainda menores chamados intercalares, que terminam nos ácinos. As células acinares são poligonais e estruturalmente dispostas em torno de um espaço central (lume) formando os ácinos. Estas estruturas podem variar em tamanho, forma e número de células (Ten Cate, 1985) (Figura 1).

O processo de secreção é regulado pelo sistema nervoso autônomo. As glândulas salivares recebem nervos motores pós-ganglionares simpáticos e parassimpáticos. Estes nervos penetram na glândula acompanhando os vasos sangüíneos e se subdividem em ramos menores até formarem as ramificações terminais junto ao parênquima final (Garret, 1987; Ten Cate, 1985).

As glândulas salivares estão envolvidas em dois processos integrados: o transporte de água e eletrólitos, controlado pela estimulação parassimpática e a secreção de proteínas, controlada pela estimulação simpática. Ambas inervações, submetidas a estímulos, liberam neurotransmissores, que por sua vez ligam-se a receptores específicos na membrana das células acinares e geram segundosmensageiros intracelulares específicos envolvidos na produção do fluido primário e na regulação da exocitose de proteínas (para revisão ver Quissell, 1992). 


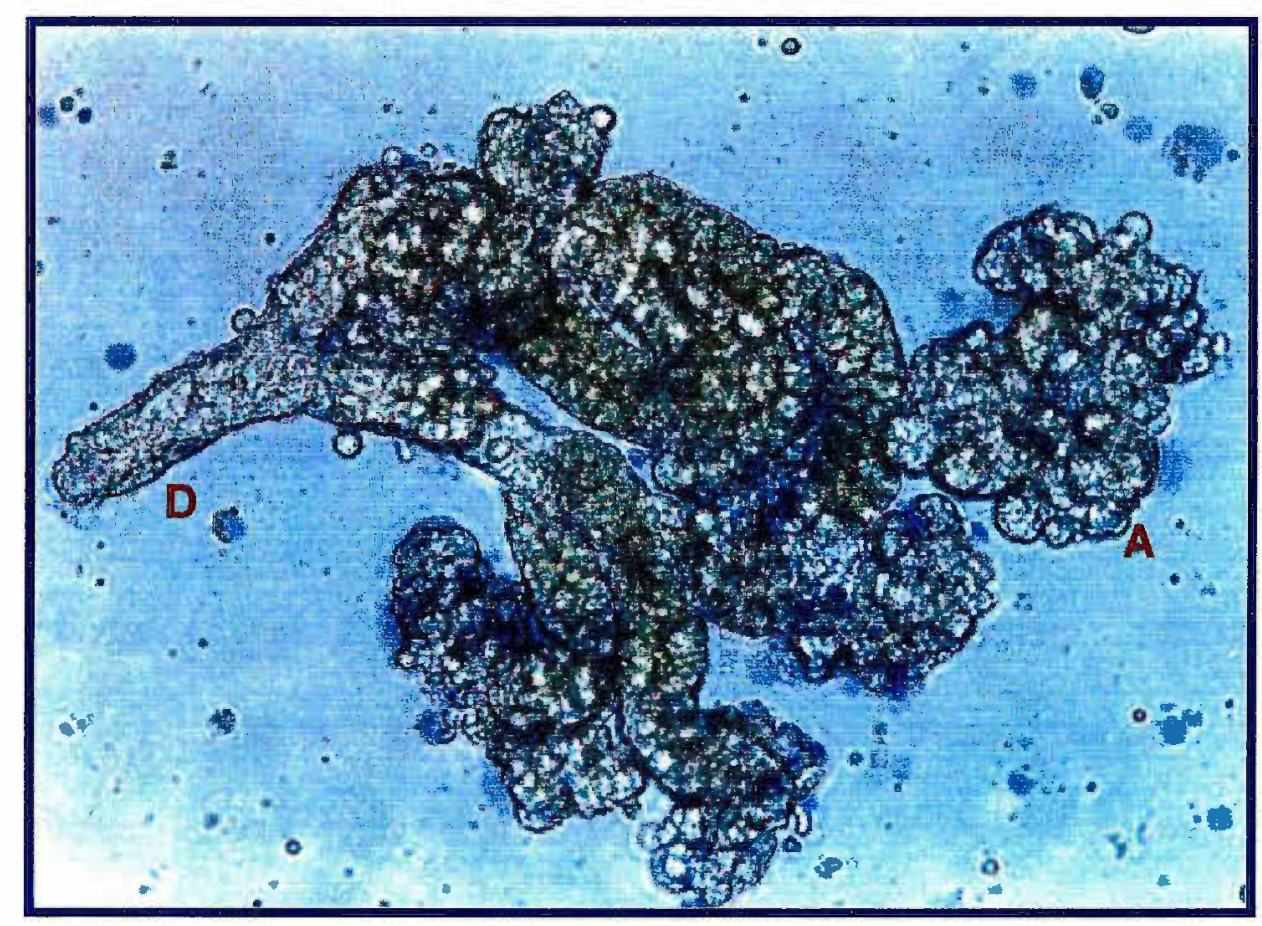

Figura 1. Estrutura das glândulas salivares. Ácinos (A) e Ductos (D). 


\subsection{Regulação fisiológica de secreção salivar}

A produção da saliva se processa em dois estágios. O primeiro ocorre nos ácinos com a expressão, estocagem e liberação de proteínas para o lume. Essa secreção, chamada de saliva primária é isotônica e sua composição é rica em $\mathrm{NaCl}$. Em seguida este produto de secreção caminha pelo canal dos ductos onde sofre modificações. Alguns íons são reabsorvidos e outros são secretados para formar a saliva final que é hipotônica, com alto conteúdo de $\mathrm{K}^{+}$, baixo conteúdo de $\mathrm{NaCl} \mathrm{e} \mathrm{Cl}^{-}$, (Martinez, 1987).

A regulação da secreção salivar ocorre por meio de transdução de sinais iniciada por receptores em membranas. Diversos deles foram identificados em glândulas salivares, como os $\alpha$-adrenérgicos (Batzri, 1973), os $\beta$-adrenérgicos (Au et al., 1977), os colinérgicos (Laniyonu et al., 1990) e os receptores para substância P (Flemming, 1984).

A seqüência de eventos intracelulares a partir da estimulação dos receptores adrenérgicos e colinérgicos tem sido muito estudada. A estimulação dos receptores $\beta$-adrenérgicos induz a uma secreção com alto conteúdo protéico e baixo volume, enquanto que a estimulação dos $\alpha$-adrenérgicos e dos colinérgicos induz a uma secreção com alto volume e baixo conteúdo protéico (Quissell \& Barzen, 1980; Martinez, 1990). Demonstrou-se que em glândula submandibular de rato a estimulação dos receptores $\beta$-adrenérgicos leva a secreção de mucina, mediada por CAMP, enquanto que a estimulação puramente colinérgica ou $\alpha$-adrenérgica não leva a secreção da mesma proteína (Quissell \& Barzen, 1980; Fleming et al., 1987) (Esquema 1). 
Estudos sobre a regulação da exocitose em glândulas salivares mostram que o processo reversivel de fosforilação de proteínas é um dos principais mecanismos reguladores. A estimulação dos receptores $\beta$-adrenérgicos leva a um aumento de CAMP intracelular com aumento concomitante da atividade da PKA, que permanece elevada durante todo o período do estímulo (Baum, 1981; Quissell et al., 1983a; Quissell, 1983b; Quissell, 1987; Quissell, 1989; Takuma, 1990).

Após a estimulação $\beta$-adrenérgica, são ativadas isoformas citossólicas de PKA, tipo I e tipo II, e também uma isoforma ligada à membrana. Durante a estimulação a PKA do tipo I sofreu maior ativação que a PKA do tipo II (Quissell et al., 1989; Quissell et al., 1988). Demonstrou-se que a ativação da PKA leva à fosforilação de diversas proteínas. Três proteínas fosforiladas foram identificadas em glândulas salivares após a estimulação $\beta$-adrenérgica: uma de peso molecular aparente 36kDa, uma de $26 \mathrm{kDa}$ (p26) e outra de $21 \mathrm{kDa}$. A p26 foi purificada, caracterizada e parece ter um papel direto na via de exocitose através da transdução de sinais mediada por CAMP (Quissell et al., 1985; Quissell et al., 1987, Quissell \& Deisher, 1992). 


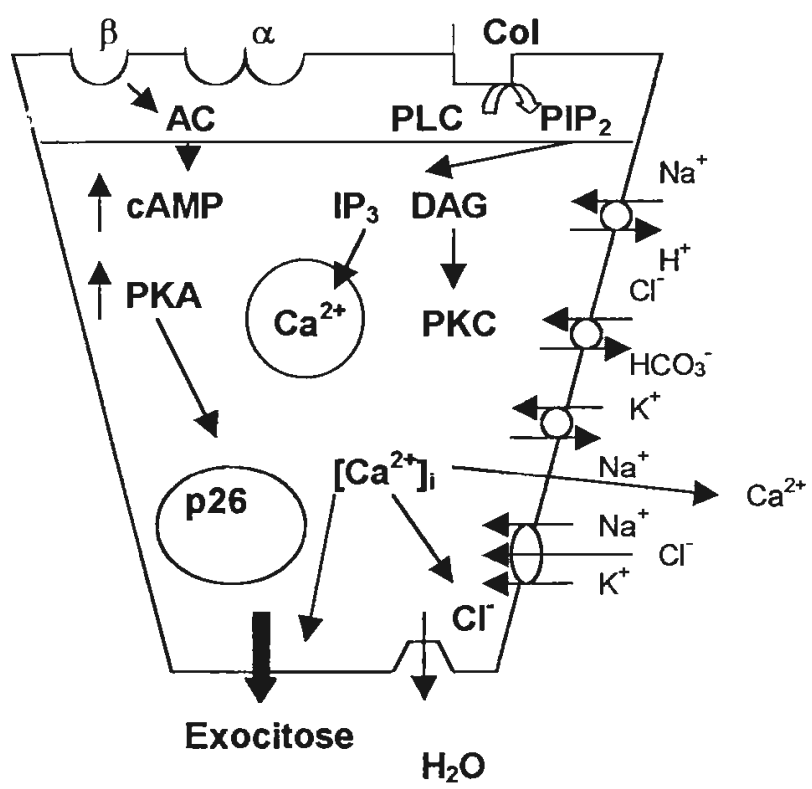

Esquema 1. Hipótese dos eventos celulares que ocorrem durante a exocitose. Durante a estimulação dos receptores $\beta$-adrenérgicos ocorre a ativação da adenilato ciclase (AC), seguida da ativação da proteína quinase A (PKA) que fosforila a fosfoproteína p26 situada na membrana das vesículas secretoras. A fosforilação da p26 permite que haja a fusão das vesículas com a membrana plasmática e que seu conteúdo seja secretado. Quando os receptores colinérgicos (Col) são ativados ocorre a quebra do fosfatidil inositol bifosfato $\left(\mathrm{PIP}_{2}\right)$ formando inositol trifosfato $\left(\mathrm{IP}_{3}\right)$ e diacilglicerol (DAG) que ativam as vesículas de cálcio e a prokefina quinase C (PKC), respectivamente. Este mecanismo estimula a abertura de canais que absorvem e liberam íons para formar a saliva primária. 


\subsection{Estímulo adrenérgico e colinérgico}

\subsubsection{Exocitose e Sialadenose}

Dado que as glândulas salivares são inervadas pelo sistema nervoso autônomo simpático e parassimpático, elas sofrem regulação por análogos de ativadores e bloqueadores deste sistema. Diversos fármacos podem atuar regulando a função destas glândulas. O agonista $\beta$-adrenérgico Isoproterenol (ISO) é um conhecido análogo da epinefrina. Sua administração é capaz de causar exocitose em glândulas salivares. Quando administrado cronicamente durante sete a quinze dias é capaz de causar sialadenose, ou seja, hipertrofia e hiperplasia das glândulas salivares por meio do mecanismo de fosforilação reversível de proteínas. (Quissell, 1983a; Brown-Grant, 1961; Schneyer, 1962; Barka, 1965).

A proliferação celular induzida por ISO é concomitante ao aumento do nível protéico de CDK (proteína quinase dependente de ciclina). O nível de CDK e de ciclinas diminui após tratamento com ISO, sugerindo que esta proliferação não seja tumorogênica (Zeng, 1996). Além dos receptores $\beta$-adrenérgicos, demonstrou-se que o ISO também induz à proliferação celular via receptor para EGF (Quissell, 1983a; Novi, 1971; Purushotham et al., 1992).

Em ratos, a sialadenose experimental (Figura 2), verificada por meio do aumento do tamanho glandular causada pela administração de ISO, pode ser revertida se o tratamento for interrompido. As glândulas voltam ao seu tamanho original. O mecanismo envolvido na regulação celular de retorno ao tamanho original das glândulas é a apoptose (Chisholm \& Adi, 1995). 


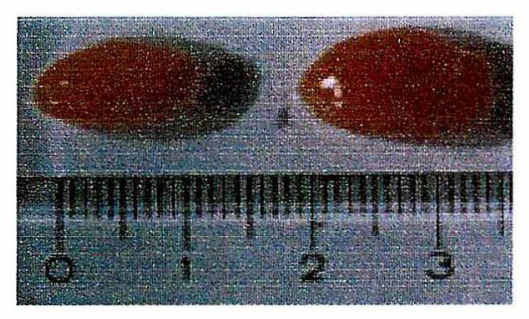

Figura 2. Sialadenose experimental. Efeito do ISO em glândulas submandibulares de rato. Tratamento com ISO (25 mg/kg) por 7 dias.

\subsubsection{Secreção Fluida}

Os receptores colinérgicos podem ser ativados por meio do carbacol (CA). Este ativador é um indutor parassimpatomimético que ativa a secreção fluida das glândulas salivares. A ativação destes receptores desencadeia o processo de produção de inositol 1,4,5-trifosfato e DAG, que estimulam a liberação de $\mathrm{Ca}^{2+}$ das vesículas causando a abertura de canais sensíveis ao $\mathrm{Ca}^{2+}$, formando a saliva primária (Hughes, P.J. et al., 1989; Martinez, 1990). As vias de ativação da secreção fluida têm sido investigadas e estudos demonstraram que a estimulação de células acinares de glândulas parótidas com carbacol leva à fosforilação de resíduos de tirosina na PKC $\delta$. Os mesmos experimentos realizados com o estímulo de ISO não promoveram a fosforilação da $\mathrm{PKC} \delta$. Estes dados reforçam dados anteriores sobre a 
regulação da secreção fluida por meio de ativadores colinérgicos e ainda acrescentam um possível papel da PKC $\delta$ e dos mecanismos de fosforilação de proteínas nesta regulação (Soltoff \& Toker, 1995).

A regulação da secreção fluida e de proteínas é dependente de energia, sendo - metabolismo de carboidratos o principal processo de produção de energia em glândulas salivares. A estimulação de glândulas salivares com ISO ativa a via glicolítica e provoca um aumento no consumo de glicose e de oxigênio. Esse consumo de oxigênio ocorre na mitocôndria e pode gerar produtos capazes de reagir com proteínas, lipídios e DNA (Nicolau \& Sassaki, 1976; Halliwell \& Guterridge, 1999).

Para melhor estudar a regulação do processo de exocitose Quissell \& Redman (1979) desenvolveram uma cultura de células acinares dispersas. Uma particularidade desta cultura é que as células somente são viáveis se a oxigenação for feita com alto teor de $\mathrm{O}_{2}$ (95\%). Também se verificou que, sob estas condições, as células em cultura reagem a ISO com a exocitose, exatamente como ocorre in vivo. Desta maneira, estas células isoladas são uma importante ferramenta de estudo. Além disto, a preparação da cultura isola somente as células acinares, separando-as das células do ducto, permitindo observações experimentais específicas ao tipo celular estudado.

Assim como se verificou um aumento no consumo de oxigênio em glândulas in vivo, em cultura de células que necessitam de alto teor de $\mathrm{O}_{2}$ para se manterem estáveis, espera-se que ocorra um aumento da quantidade de produtos derivados do oxigênio. Embora existam estudos sobre os efeitos de produtos de oxigênio em diversos tecidos, não há relatos de pesquisa em glândulas salivares. 


\subsection{Espécies reativas de oxigênio e suas implicações}

\section{biológicas}

O oxigênio molecular $\left(\mathrm{O}_{2}\right)$ surgiu na Terra há 2,5 bilhões de anos. Microorganismos essencialmente anaeróbios não são capazes de sobreviver em presença de $\mathrm{O}_{2}$, pois ele é um elemento capaz de oxidar vários componentes celulares. Desta forma, organismos que toleram $\mathrm{O}_{2}$ (aeróbios) puderam se adaptar e desenvolveram mecanismos de proteção contra os efeitos do $\mathrm{O}_{2}$. (Halliwell \& Guterridge, 1999).

$\mathrm{O} \quad \mathrm{O}_{2}, \quad\left[\mathrm{O}_{2}\left({ }^{3} \Sigma_{g}^{-}\right)\right]$, é uma molécula estável que contém dois elétrons desemparelhados em diferentes orbitais, mas com o mesmo spin. $\mathrm{O} \mathrm{O}_{2}$ pode receber energia de sistemas bioquímicos e fotoquímicos e gerar formas mais reativas como o oxigênio singlete $\mathrm{O}_{2}\left({ }^{1} \Delta_{g}\right)$ e $\mathrm{O}_{2}\left({ }^{1} \Sigma_{g}{ }^{+}\right)$. Comparando as formas do oxigênio em termos de energia $\circ \mathrm{O}_{2}\left({ }^{1} \Delta_{g}\right)$ é um estado com maior energia que $\circ \mathrm{O}_{2}\left({ }^{3} \Sigma_{g}{ }^{-}\right)$, porém com menor energia que $\mathrm{O}_{2}\left({ }^{1} \Sigma_{\mathrm{g}}{ }^{+}\right)$. (Weldon, 1999).

$\mathrm{O} \mathrm{O}_{2}$ nos organismos aeróbios atua como receptor final de elétrons. Ele é reduzido a água durante a respiração celular que ocorre na mitocôndria. Este processo, associado ao da fosforilação oxidativa, resulta em uma alta produção de ATP, que é essencial para a manutenção do equilíbrio energético destes organismos. Sob certas condições $0 \mathrm{O}_{2}$ pode sofrer reduções que levam à produção de derivados chamados de espécies reativas de oxigênio (ERO), sendo que algumas podem causar diversos danos celulares (Halliwell \& Guterridge, 1999; Gaté et al., 1999; RichterLandsberg \& Vollgraf, 1998). 
As ERO são geradas in vivo de diversas maneiras. A mitocôndria, por meio do processo de respiração celular requer $\mathrm{O}_{2}$ para produção de ATP. Observa-se que durante esta etapa existe um escape de elétrons que podem reagir diretamente com $\circ \mathrm{O}_{2}$ produzindo ânion superóxido $\left(\mathrm{O}_{2}{ }^{\bullet}\right)$. Em condições normais, o $\mathrm{O}_{2}$ recebe quatro elétrons e se reduz formando $\mathrm{H}_{2} \mathrm{O}$. Quando $\mathrm{o} \mathrm{O}_{2}$ recebe um ou dois elétrons, ocorre a formação do $\mathrm{O}_{2} \cdot-$ e do peróxido de hidrogênio $\left(\mathrm{H}_{2} \mathrm{O}_{2}\right)$ respectivamente. $\mathrm{O}_{2} \mathrm{O}_{2}$ também pode ser reduzido e formar o radical hidroxil $\left(\mathrm{HO}^{\circ}\right)$ como está ilustrado no esquema 2 (Boveris \& Chance, 1973).

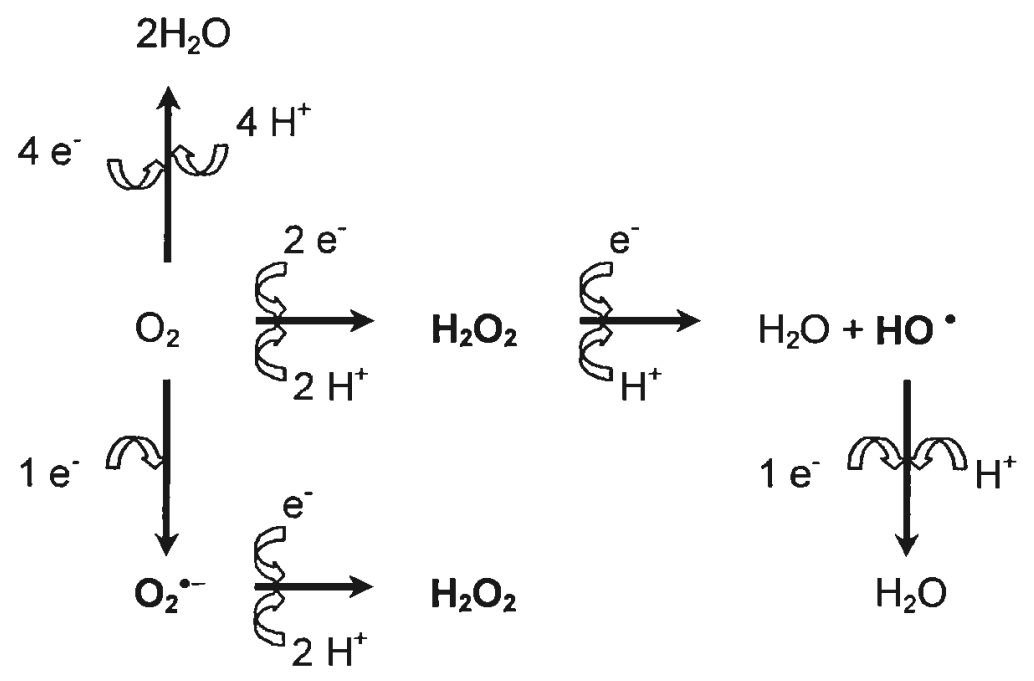

Esquema 2. Etapas de redução do oxigênio e seus derivados reativos. 
Os intermediários reativos formados a partir da redução do $\mathrm{O}_{2}$ podem agir de diversas formas. $\mathrm{O} \mathrm{H}_{2} \mathrm{O}_{2}$ tem a capacidade de se difundir pela membrana plasmática sendo capaz de inativar enzimas por oxidação do grupo tiol, mas também pode desempenhar funções como ativação de fatores de transcrição como o NFKB e AP-1, além de agir como segundo mensageiro intracelular (Peus et al., 1999; Müller et al., 1997; Gaté et al., 1999; Matés, 2000).

O intermediário $\mathrm{O}_{2} \cdot-$ é pouco reativo, mas quando ele se reduz de forma univalente, há a formação de $\mathrm{H}_{2} \mathrm{O}_{2}$ que também pode reduzir-se formando $\mathrm{HO}^{\circ}$. Outra forma de geração de $\mathrm{HO}^{\circ}$ é pelas reações catalisadas por metais de transição, conhecidas como reações de Fenton e Haber-Weiss (esquema 3). O HO é uma espécie muito reativa e causadora de diversos efeitos deletérios em sistemas biológicos como, por exemplo, a destruição da integridade da membrana celular e a modificação de bases do DNA (Halliwell \& Gutteridge, 1999).

$$
\begin{aligned}
& \mathrm{H}_{2} \mathrm{O}_{2}+\mathrm{Fe}^{2+} \longrightarrow \mathrm{Fe}^{3+}+\mathrm{HO}^{-}+\mathrm{HO}^{-} \quad \text { Reação de Fenton } \\
& \mathrm{H}_{2} \mathrm{O}_{2}+\mathrm{O}_{2}^{-}+\mathrm{Fe}^{2+} \longrightarrow \mathrm{Fe}^{3+}+\mathrm{O}_{2}+\mathrm{HO}^{-}+\mathrm{HO}^{-} \text {Reação de Haber-Weiss }
\end{aligned}
$$

Esquema 3. Reacōes de formação de ERO, catalisadas por $\mathrm{Fe}^{2+}$. 


\subsection{Sistemas antioxidantes}

Os organismos aeróbios são providos de sistemas antioxidantes que em condições fisiológicas são suficientes para prevenir possíveis danos a estruturas celulares causados durante 0 estresse oxidativo. Esta condição de estresse, que ocorre quando há um desequilíbrio entre a produção de ERO e a capacidade de proteção dos sistemas antioxidantes, pode resultar em danos celulares como a peroxidação de ácidos graxos, oxidação de proteínas, de carboidratos e de DNA. A oxidação da molécula de DNA produz 8-oxo-2'-deoxiguanosina ( $0 \times 0^{8} \mathrm{dG}$ ) que está associada à mutagênese e está relacionada ao envelhecimento. Além destas causas específicas, o estresse oxidativo também tem sido implicado em diversos processos e patologias como o câncer, a inflamação, a apoptose, o crescimento e a diferenciação celular (esquema 4) (Stadtman, 1990; Halliwell \& Gutteridge, 1999; Floyd, 1990; Gaté et al., 1999; Matés \& Sánchez-Jiménez, 2000).

Os sistemas de proteção contra o estresse oxidativo podem ser classificados como enzimáticos e incluem as enzimas superóxido dismutase (SOD), catalase (CAT), glutationa peroxidase (GPx), e não enzimáticos como a vitamina $E$, a vitamina $C$ e carotenóides entre outros (Gaté, 1999).

No sistema enzimático, a SOD é a enzima antioxidante que age como a primeira defesa celular contra o estresse oxidativo. Ela converte $\circ \mathrm{O}_{2}{ }^{\cdot-}$ a $\mathrm{H}_{2} \mathrm{O}_{2}$ e oxigênio molecular $\mathrm{O}_{2}$. A CAT é uma enzima que consiste de quatro subunidades, cada uma contendo um grupo heme. Ela catalisa uma reação de dismutação em que converte $\mathrm{H}_{2} \mathrm{O}_{2}$ em $\mathrm{H}_{2} \mathrm{O}$ e O $\mathrm{O}_{2}$. (Reid, 1981; Gaté, 1999). 
A enzima GPx em animais é dependente de selênio e catalisa uma reação utilizando como substrato o tripeptídeo glutationa reduzida (GSH), considerado o maior grupo tiol não protéico do organismo humano. Nesta reação a glutationa reduzida é oxidada (GSSG) e serve como doadora de $H$ para que ocorra a redução de $\mathrm{H}_{2} \mathrm{O}_{2}$ a $\mathrm{H}_{2} \mathrm{O}$. A GSSG pode ser novamente reduzida a GSH por meio da reação enzimática catalisada pela glutationa redutase (GR) via oxidação de NADPH a NADP ${ }^{+}$ (Halliwell \& Gutteridge, 1999; Gaté, 1999). As principais reações enzimáticas antioxidantes estão mostradas no esquema 5. 

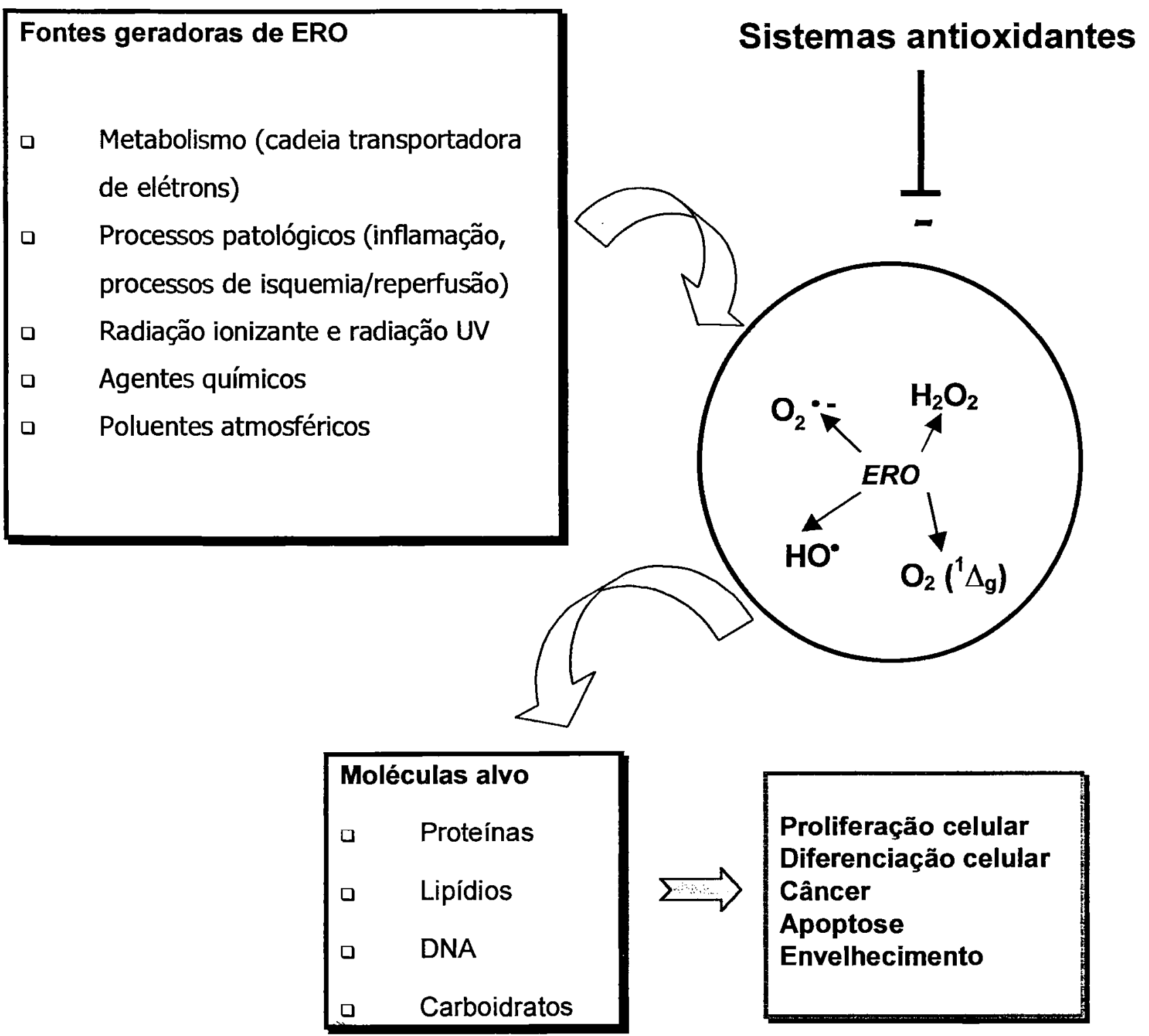

Esquema 4. Fatores geradores de estresse oxidativo e suas conseqüências. ERO geradas podem reagir com macromoléculas como proteínas, lipídios e DNA, promovendo o dano celular. Os sistemas antioxidantes atuam sobre as ERO impedem que ocorra o estresse oxidativo. 
Esquema 5. Reações catalisadas pelas enzimas antioxidantes:

$$
\begin{aligned}
& 2 \mathrm{H}_{2} \mathrm{O}_{2} \stackrel{\mathrm{CAT}}{\longrightarrow} \mathrm{H}_{2} \mathrm{O}+\mathrm{O}_{2} \\
& \mathrm{H}_{2} \mathrm{O}_{2}+2 \mathrm{GSH} \stackrel{\mathrm{GPx}}{\longrightarrow} 2 \mathrm{H}_{2} \mathrm{O}+\mathrm{GSSG} \\
& \mathrm{GSSG}+\mathrm{NADPH}+\mathrm{H}^{+} \stackrel{\mathrm{GR}}{\longrightarrow} 2 \mathrm{GSH}+\mathrm{NADP}^{+} \\
& \mathrm{O}_{2} \cdot-+\mathrm{O}_{2} \cdot-+2 \mathrm{H}^{+} \stackrel{\text { SOD }}{\longrightarrow} \mathrm{H}_{2} \mathrm{O}_{2}+\mathrm{O}_{2}
\end{aligned}
$$

A SOD, que age como a primeira defesa contra ERO, possui diferentes isoformas que foram isoladas de diversos organismos. Os mamíferos têm três isoformas de SOD (CuZnSOD, MnSOD e ECSOD). A CuZnSOD está localizada no citossol e a MnSOD está localizada na mitocôndria. A CuZnSOD contém duas subunidades idênticas de $16 \mathrm{kDa}$. Cada subunidade contém um $\mathrm{Cu}^{2+}$ e um $\mathrm{Zn}^{2+} \mathrm{em}$ seu sítio ativo. A MnSOD é um dímero contendo subunidades de aproximadamente $20 \mathrm{kDa}$. Elas contêm $\mathrm{Mn}^{2+}$ em seu sítio ativo que auxilia a catálise das reações (Fridovich, 1974; Fridovich, 1995).

A atividade de CuZnSOD e de MnSOD pode ser regulada por diferentes mecanismos. A radiação UVB provoca um aumento em sua atividade de CuZnSOD, mas não altera a atividade de MnSOD nas mesmas condições de tratamento. Já o aumento da atividade enzimática de MnSOD, assim como a indução de seu mRNA 
ocorreram quando as células foram tratadas com TNF- $\alpha$ e IL-6. (Isoherranen et al., 1997; Hachiya et al., 1997).

Diversas evidências sugerem que as SODs podem ser reguladas e podem regular diversos mecanismos por meio das vias de transdução de sinais intracelulares. No primeiro caso a regulação por indução do gene da MnSOD tem sido explicada por mecanismos que envolvem a fosforilação de proteínas. Demonstrou-se que a expressão de mRNA para a isoforma MnSOD é induzida por tratamento com cicloheximida (CHX), um conhecido inibidor da síntese protéica (Fuji et al., 1994). Já no segundo caso levanta-se a hipótese de que a MnSOD regule um mecanismo tumoral, agindo como um supressor de tumor. Esta hipótese foi sugerida a partir de estudos que mostram a supressão de tumor em células de fibrossarcoma a partir da superexpressão de MnSOD que regula negativamente o complexo AP-1 (Irani et al., 1997; Kiningham \& Clair, 1997).

Embora a atividade e expressão de SOD tenham sido estudadas em diversos tecidos, ainda não existem relatos sobre a atividade de SOD em glândulas salivares de rato.

Nosso trabalho propõe o estudo da modulação do estresse oxidativo em glândulas submandibulares de rato devido à inexistência de relatos sobre os efeitos das ERO em glândulas salivares e também devido ao desconhecimento sobre a ação de sistemas antioxidantes nestas glândulas. 


\section{Objetivos}

O mecanismo de secreção salivar pode ser induzido por agonistas de receptores adrenérgicos e colinérgicos. Estes desencadeiam a secreção protéica e fluida, ativando intensamente o metabolismo aeróbio. Embora o mecanismo de ação destes agonistas seja muito conhecido, pouco se sabe sobre os efeitos destes agentes no estresse oxidativo em glândulas salivares. Sendo assim, nossa proposta de estudo foi:

- Determinar o dano oxidativo em lipídios e proteínas in vivo e em cultura de células.

- Determinar o poder redutor a partir da medida do conteúdo de GSH in vivo e em cultura de células.

- Determinar o perfil protéico de SOD in vivo.

a Determinar a atividade enzimática de SOD in vivo e em cultura de células

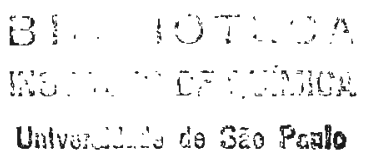




\section{Materiais e Métodos}

\subsection{Tampão e meio de cultura utilizados}

Tampão de lise - HEPES 25 mM, $\mathrm{NaCl} 300 \mathrm{mM}, \mathrm{MgCl}_{2}$ 1,5 mM, EDTA 0,2 mM, DTT 0,5 mM, $\beta$-glicerofosfato $20 \mathrm{mM}$, Triton $\mathrm{X}-100$ e inibidores de protease. A solução foi mantida a $4^{\circ} \mathrm{C}$.

Meio de cultura - Meio DME (Sigma). O meio foi oxigenado com a mistura $95 \% \mathrm{O}_{2} / 5 \% \mathrm{CO}_{2}$ e os experimentos foram realizados a $37^{\circ} \mathrm{C}$.

\subsection{Animais}

O modelo de estudo foi a glândula submandibular de ratos machos da linhagem Sprague-Dawley pesando 180 a $220 \mathrm{~g}$ com livre acesso a alimento e água. Os ratos foram subdivididos em um grupo controle e em grupos experimentais, sendo que cada grupo experimental recebeu um tratamento diferente.

\subsection{Injeções}

3.3.1. Tratamento com isoproterenol (ISO), Carbacol (CA) ou cicloheximida (CHX)

Um grupo de animais recebeu injeções subcutâneas com ISO (50 mg/kg), outro com $\mathrm{CA}(0,3 \mathrm{mg} / \mathrm{kg})$ e outro com $\mathrm{CHX}(50 \mathrm{mg} / \mathrm{kg})$. O grupo controle recebeu injeções de $\mathrm{NaCl} 0,9 \%$ de volumes equivalentes aos animais tratados com ISO, CA e CHX. 
Os animais foram sacrificados após 10, 20, 30 e 60 min da injeção. Para a remoção das glândulas foi realizada uma incisão central na altura do pescoço e rapidamente as glândulas submandibulares foram dissecadas das glândulas sublinguais (Esquema 5) e homogeneizadas como será descrito em 3.3.3.

\subsubsection{Pré-tratamento com CHX seguido de tratamento com ISO}

As células de glândulas salivares são especializadas no processo de síntese protéica e exocitose. Sabe-se que o ISO provoca um aumento na transcrição e estimula a exocitose. Para estudarmos o efeito agudo do ISO sobre estas células, utilizamos a $\mathrm{CHX}$, um inibidor de síntese protéica previamente ao estímulo com ISO. A injeção de $\mathrm{CHX}$ foi feita e após $1 \mathrm{~h}$ foi injetado ISO. Os animais foram sacrificados 10, 20, 30 e 60 min após a injeção com ISO, as glândulas foram removidas e homogeneizadas como descrito a seguir.

\subsubsection{Preparação do homogenado e determinação de proteínas}

As glândulas removidas foram homogeneizadas mecanicamente a $4^{\circ} \mathrm{C}$ com tampão de lise. Os homogenados foram deixados em gelo durante 20 min e em seguida o homogenado foi centrifugado a $12500 \times \mathrm{g}$ por 5 min e o sobrenadante foi utilizado para as medidas de atividade total de SOD, glutationa total, nível de MDA produzidos e peroxidação protéica.

A determinação de proteína do sobrenadante foi feita segundo o método de Bradford (1976), utilizando albumina bovina sérica (BSA) como proteína padrão para a curva de calibração. 


\subsection{Cultura de células dispersas}

\subsubsection{Procedimento de isolamento das células acinares}

Para os experimentos realizadios in vitro utilizamos a cultura primária de células epiteliais acinares de glândula submandibular de rato como descrito por Quissell \& Redman (1979) modificado, como detalhado a seguir (Esquema 5).

As glândulas submandibulares retiradas foram colocadas imediatamente no meio de cultura contendo colagenase $3 \mathrm{U} / \mathrm{mg}$ de tecido e hialuronidase $10 \mathrm{U} / \mathrm{mg}$ de tecido, $\mathrm{pH} 7,4$ equilibrado durante $30 \mathrm{~min}$ a $37^{\circ} \mathrm{C}$ e oxigenado constantemente com $95 \% \mathrm{O}_{2} / 5 \% \mathrm{CO}_{2}$.

As glândulas foram picadas em pedaços de aproximadamente $1 \mathrm{~mm}$ e colocadas em erlenmeyer siliconizado contendo o mesmo meio com agitação de 125 rpm por $60 \mathrm{~min}$. $\mathrm{O}$ tecido foi oxigenado novamente e a checagem do pH foi feita nos tempos $0,10,15,30,45,55$ e $60 \mathrm{~min}$, sendo que nos tempos $30,45,55$ e 60 min as células foram dispersas com movimentos suaves para cima e para baixo, utilizandose uma pipeta sorológica estéril. Após 60 min as células foram lavadas duas vezes (1000 $\times \mathrm{g}$ por $2 \mathrm{~min}$ ) em temperatura ambiente, com meio de cultura $\mathrm{pH} 7,4$ contendo BSA $1 \%$ e oxigenado. Em seguida as células foram filtradas em meia de nylon preparada previamente com lavagem em EDTA $50 \mathrm{mM}$.

A porção que passou pelo filtro foi utilizada como fonte de células acinares. Essa porção filtrada foi lavada duas vezes com meio de cultura contendo BSA $1 \%$, oxigenado (1000 $\times \mathrm{g}$ por $2 \mathrm{~min}$ ) em temperatura ambiente e foi colocada em 
erlenmeyer siliconizado contendo meio de cultura com BSA 1\%, pH 7,4, oxigenado, a $37^{\circ} \mathrm{C}$ e a $125 \mathrm{rpm}$.

Essa cultura dispersa foi colocada em agitador a $125 \mathrm{rpm}$ por $30 \mathrm{~min}$ a $37^{\circ} \mathrm{C}$ sob oxigenação constante para estabilização e em seguida foram divididas em erlenmeyer menores utilizando hematócrito $5 \%$ para a realização dos ensaios. A viabilidade celular foi feita usando-se trypan blue $0,5 \%(p / v)$. 

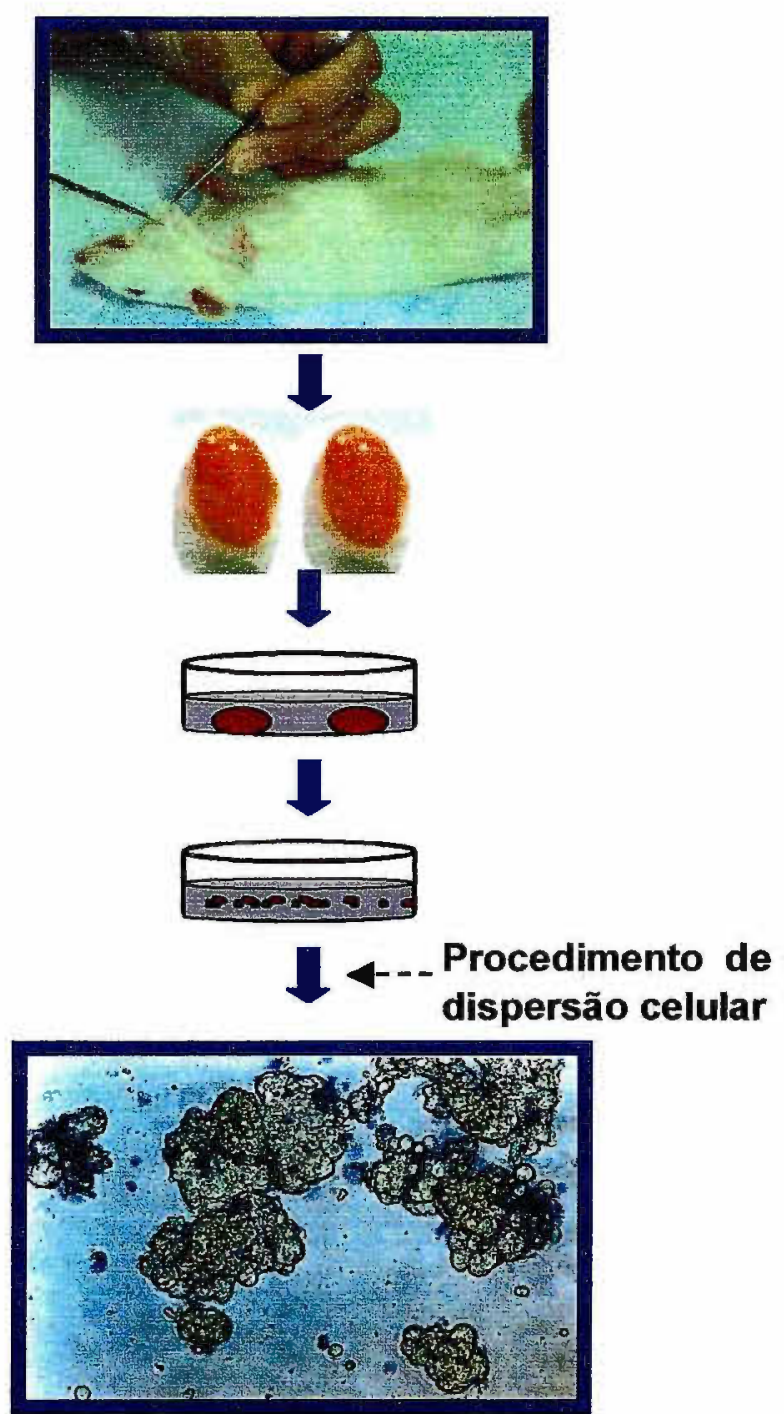

1

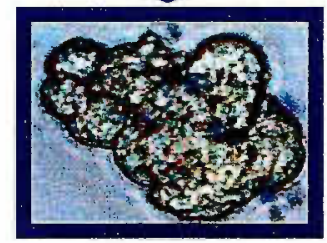

Hematócrito $5 \%$

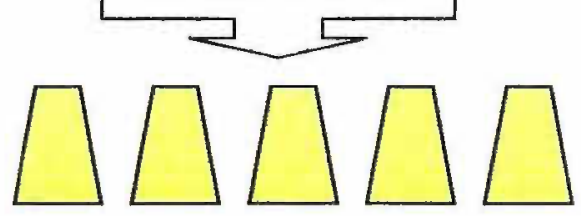

Esquema 5. Procedimento de remoção das glândulas submandibulares e isolamento de ácinos. Observação da viabilidade dos ácinos utilizando trypan-blue, ao microscópio óptico com aumento de 100X. 


\subsection{Ensaios in vitro}

\subsubsection{Ação de ISO, CHX, CA e Propanolol (PROP) em células acinares}

A cultura de células acinares foi dividida em 5 grupos e oxigenada por 30 min antes do ensaio para sua estabilização. Em seguida foi realizado o ensaio com ISO (agonista $\beta$-adrenérgico), $\mathrm{CHX}$ (inibidor da síntese protéica), CA (agonista colinérgico) e PROP (bloqueador $\beta$-adrenérgico). Com estes ensaios pretendeu-se verificar a ação destes fármacos, relatados anteriormente, na modulação do estresse oxidativo nestas células em cultura.

Grupo I: A cultura de células acinares foi incubada com ISO $10 \mu \mathrm{M}$, conhecido por induzir a exocitose e o metabolismo aeróbio. Amostras foram retiradas após 10, 20, 30 e 60 min e em seguida os homogenados foram feitos e analisados.

Grupo II: A cultura de células acinares foi incubada com $\mathrm{CHX} 10 \mathrm{mg} / \mathrm{mL}$, um inibidor da síntese protéica e conhecido por induzir in vitro a expressão de mRNA da MnSOD. Amostras foram retiradas após 10, 20, 30 e 60 min e em seguida os homogenados foram feitos e analisados.

Grupo III: A cultura de células acinares foi incubada com $\mathrm{CHX} 10 \mathrm{mg} / \mathrm{mL}$ por $30 \mathrm{~min}$, seguida de incubação com ISO $10 \mu \mathrm{M}$ para estudarmos o efeito agudo do ISO sobre estas células, em relação ao estresse oxidativo. Amostras foram retiradas após 10, 20, 30 e 60 min e em seguida os homogenados foram feitos e analisados.

Grupo IV: A cultura de células acinares foi incubada com CA $10 \mu \mathrm{M}$, um indutor da secreção salivar fluida. Amostras foram retiradas após 10, 20, 30 e 60 min e em seguida os homogenados foram feitos e analisados. 
Grupo V: A cultura de células acinares foi incubada com PROP $20 \mu \mathrm{M}$, um bloqueador $\beta$-adrenérgico por 5 min, seguida da incubação com ISO $10 \mu \mathrm{M}$. Amostras foram retiradas após 10, 20, 30 e 60 min e em seguida os homogenados foram feitos e analisados.

As células foram removidas em 10, 20, 30 e 60 min após o estímulo e separadas do meio por centrifugação a $5000 \times \mathrm{g}$. Elas foram sonicadas em tampão de lise a $4^{\circ} \mathrm{C}$ com 10 pulsos de 5 segundos com intervalo de 15 segundos entre cada pulso. Os homogenados foram centrifugados a $12500 \times \mathrm{g}$ por 5 min e utilizados para a realização dos ensaios de determinação de atividade total de SOD, glutationa total, nível de MDA produzidos e peroxidação protéica.

A determinação de proteína do sobrenadante foi feita segundo o método de Bradford (1976), utilizando albumina bovina sérica BSA como padrão para a curva de calibração.

3.5.2. Controle da atividade de SOD no extrato sob ação de ISO, CHX e CA.

Animais controles foram sacrificados e suas glândulas removidas. Homogenados a $1 \mathrm{mg} / \mathrm{mL}$, obtidos como descrito em 3.3 .3 foram incubados a $37^{\circ} \mathrm{C}$ com CA $(10 \mu \mathrm{M})$, ISO $(10 \mu \mathrm{M})$ e $\mathrm{CHX}(10 \mathrm{mg} / \mathrm{mL})$ foram adicionados ao meio por 20 min e em seguida foi medida a atividade total de SOD. 


\subsection{Atividade Antioxidante}

\subsubsection{Atividade de SOD}

Para a determinação da atividade da SOD foi utilizado o método descrito por McCord \& Fridovich (1968). Utiliza-se no meio de reação a hipoxantina, a enzima xantina oxidase e o citocromo c. Nesta reação, que ocorre sob condições aeróbias, a enzima xantina oxidase atua sobre a hipoxantina, seu substrato, gerando $\mathrm{O}_{2}{ }^{-}$. Este ânion age sobre o citocromo c (cit. c), reduzindo o $\mathrm{Fe}^{3+}$ a $\mathrm{Fe}^{2+}$, que pode ser visualizada espectrofotometricamente a $550 \mathrm{~nm}$, que é o comprimento de onda relativo ao pico de absorbância do cit. $c-\mathrm{Fe}^{2+}$. A SOD captura $0 \mathrm{O}_{2}{ }^{--}$, inibe a redução do $\mathrm{Fe}^{3+}$, sendo observada na curva de absorbância. Esta curva foi monitorada durante $1 \mathrm{~min}$ a $550 \mathrm{~nm}$. Neste ensaio, uma unidade de atividade é definida como a quantidade de enzima que promove $50 \%$ de inibição da redução do cit. $c$ por $\min$, à $25^{\circ} \mathrm{C}$ e em pH 7,8. O meio de reação foi composto por $55 \mu \mathrm{M}$ de hipoxantina, 22,5 mM cit. $c$ e um volume variado de homogenado celular e tampão fosfato $0,1 \mathrm{M}$, pH 7,8. A reação é iniciada pela adição de xantina oxidase $(0,3 \mathrm{U} / \mathrm{mL})$.

\subsubsection{Determinação dos níveis protéicos de SOD e análise por "Western Blot"}

Para determinar os níveis protéicos de SOD foi realizada uma eletroforese em gel de poliacrilamida contendo SDS (SDS-PAGE) foi feita segundo Laemmli (1970), no sistema para eletroforese em placa Mini-Protean II (Bio-Rad Laboratories).

A concentração de acrilamida utilizada no gel de separação foi $12 \%$ no gel de empilhamento foi de $4,5 \%$, sendo que a espessura do gel utilizada foi de $0,75 \mathrm{~mm}$. 
As amostras foram misturadas ao tampão de amostra para obter a concentração final de Tris- $\mathrm{HCl}$ 50mM pH 6,8, DTT 25mM, glicerol $10 \%(\mathrm{v} / \mathrm{v})$, SDS $1 \%(\mathrm{p} / \mathrm{v})$ e $0,08 \mu \mathrm{g} / \mathrm{ml}$ de azul de bromofenol. Em seguida, foram fervidas por 10min antes de sua aplicação no gel. Iguais concentrações $(50 \mu \mathrm{g})$ de proteínas totais foram aplicados por amostra no gel e a corrida eletroforética foi realizada sob amperagem constante de $15 \mathrm{~mA}$ para o empilhamento e 25 mA para a separação dos polipeptídeos.

Após a corrida, os polipeptídeos foram transferidos para membranas de PVDF segundo Towbin et al. (1979), modificado. A transferência foi realizada por $1 \mathrm{~h} 30$ min em corrente constante de $250 \mathrm{~mA}$ com tampão Tris $25 \mathrm{mM}$, Glicina $130 \mathrm{mM}$ e metanol $20 \%(\mathrm{v} / \mathrm{v})$ e as bandas foram visualizadas com Coomassie blue. As membranas foram bloqueadas com leite desnatado $5 \%$ em TBS-T (Tris $50 \mathrm{mM}, \mathrm{NaCl}$ $150 \mathrm{mM}$, tween-20 0,05\%) de um dia para outro a $4^{\circ} \mathrm{C}$. Em seguida foram lavadas com TBS-T por 30 min e incubadas com o anticorpo primário diluído (1:1000) por $2 \mathrm{~h}$ à temperatura ambiente. Após a lavagem com TBS-T por $30 \mathrm{~min}$, elas foram incubadas por $1 \mathrm{~h}$ à temperatura ambiente com o anticorpo secundário conjugado à peroxidase (1:5000). A revelação foi feita usando os reativos do "kit" de quimiluminescência ECL (Amersham-Pharmacia). A densitometria foi realizada por comparação entre as bandas, tomando por base a canaleta do grupo controle, utilizando o aparelho VDS Image Master (Amersham-Pharmacia). 


\subsection{Determinação de estresse oxidativo}

\subsubsection{Poder Redutor}

O estresse oxidativo pode ser medido por meio da estimätiva do conteúdo de GSH em relação à sua forma oxidada GSSG (Sies, 1999). A determinação de tióis totais foi realizada de acordo com o método colorimétrico descrito por Murphy \& Keher (1989). As células foram homogeneizadas em 0,5 M de ácido perclórico contendo $5 \mathrm{mM}$ de EDTA e $0,06 \%$ de bipiridina. Após a centrifugação a $10.000 \times \mathrm{g}$ por $10 \mathrm{~min}$, alíquotas do sobrenadante (tióis solúveis) foram misturadas com $2 \mathrm{mM}$

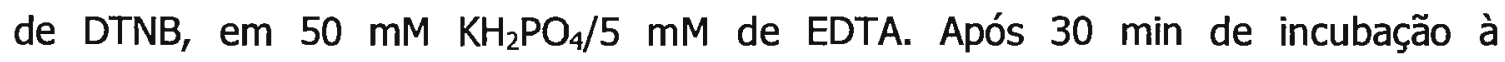
temperatura ambiente, foi medida a absorbância a $412 \mathrm{~nm}$, relativa à formação do produto TNB. A glutationa total (GSH+2GSSG) foi medida em um meio de reação contendo aliquotas das amostras, 0,6 mM de DTNB, 0,2 mM de NADPH e 0,1 U/mL de GR, em um tampão 50 mM KH2PO4/5 mM EDTA. O aumento da absorbância a $412 \mathrm{~nm}$ foi monitorado durante 2 min e os dados foram calculados em nmol de tióis (equivalentes de GSH) por mg de proteínas totais. O poder redutor foi estimado pela relação GSH/(GSH+2GSSG).

\subsection{Determinação de lesões oxidativas}

\subsubsection{Medida da produção de MDA}

Durante a peroxidação lipídica é gerado o malondialdeído (MDA) que é capaz de reagir com o ácido tiobarbitúrico. O ensaio foi realizado segundo Esterbauer \& Cheeseman (1990). Acrescentou-se $150 \mu \mathrm{L}$ de TCA 20\% (p/v em 0,25 M de HCl) e 
$15 \mu \mathrm{L}$ de hidroxi-butil-tolueno $4 \%$ a $150 \mu \mathrm{L}$ de homogenado. A mistura foi deixada em gel por 30 min e centrifugada a $2400 \times$ g por 2 min. Adicionou-se $300 \mu \mathrm{L}$ de ácido tiobarbitúrico 0,7\% (p/v em 0,25 M de $\mathrm{HCl})$ ao sobrenadante e em seguida a mistura foi aquecida a $95^{\circ} \mathrm{C}$ em água por $30 \mathrm{~min}$. Após o resfriamento a absorbância foi lida a $535 \mathrm{~nm}$. Os valores foram expressos como nmol de MDA por miligrama de proteína total $\left(\varepsilon 535 \mathrm{~nm}=153 \mathrm{mM}^{-1} \cdot \mathrm{cm}^{-1}\right)$.

\subsubsection{Oxidação protéica}

As proteínas sofrem danos oxidativos que podem ser estimados pelo conteúdo de carbonilas protéicas das amostras (Rice-Evans et al., 1991). Para a determinação das carbonilas, homogenados celulares foram incubados com $10 \mathrm{mM}$ de 2,4-dinitro fenil hidrazina por $1 \mathrm{~h}$, à temperatura ambiente. Em seguida as proteínas foram precipitadas com ácido tricloroacético $20 \%(\mathrm{p} / \mathrm{v})$, lavadas 2 vezes com etanol/acetato de etila (1:1) e dissolvidas em solução $6 \mathrm{M}$ de guanidina. $O$ conteúdo de carbonilas foi avaliado por medidas de absorbância a $370 \mathrm{~nm}$. Os valores encontram-se expressos em nmol de carbonilas por $\mathrm{mg}$ de proteínas totais $\left(\varepsilon=22.000 \mathrm{M}^{-1} \cdot \mathrm{cm}^{-1}\right)$.

\subsection{Análise Estatística}

Os resultados expressos nos gráficos apresentados neste trabalho representam a média de três experimentos independentes $(n=3)$, sendo que a barra do desvio padrão é mostrada para cada valor apresentado. A análise estatística utilizada para a verificação das diferenças dos grupos em relação ao grupo controle foi o Teste $t$ de Student, aceitando-se o nível de $5 \%$ de significância $(p<0,05)$. 


\section{Resultados}

\subsection{Níveis de MDA produzidos in vivo.}

As glândulas salivares têm a função de estocar e secretar proteínas, sendo que o processo de estocagem é feito em vesículas lipoprotéicas. Portanto, a integridade das membranas é um fator importante para a manutenção da função celular. Sabe-se que as ERO produzidas durante o estresse oxidativo podem causar oxidação de proteínas e de lipídios. Um dos objetivos deste trabalho foi avaliar as lesões oxidativas produzidas em lipídios de glândulas submandibulares de rato.

Doses agudas de ISO (agonista $\beta$-adrenérgico) e de $\mathrm{CHX}$ (inibidor da síntese protéica) foram utilizadas e o nível de lesões oxidativas produzidas em lipídios com os tratamentos in vivo foi avaliado.

Os animais receberam injeções com ISO (50 mg/kg) ou CHX (50 mg/Kg) ou $\mathrm{NaCl}$ 0,9\% (controle). As glândulas submandibulares foram removidas em 10, 20, 30 e 60 min e os níveis de MDA produzidos foram estimados segundo o método descrito no item 3.8.1. Nos grupos de animais tratados somente com ISO foi observado um aumento significativo na produção de MDA por mg de proteína em relação ao grupo controle (10 min, 17\%; $20 \mathrm{~min}, 28 \%$; $30 \mathrm{~min}, 23 \%$ e $60 \mathrm{~min}, 60 \%$ ) (Fig. 1 ).

Resultados semelhantes foram obtidos com animais tratados somente com CHX nos quais foram observados aumentos significativos na produção de MDA por mg de proteína em relação ao grupo controle (10 min, 22\%; 20 min, 33 \%; 30 min, $30 \% ; 60 \mathrm{~min}, 80 \%$ ) (Fig.2). 
Como os mecanismos de ação do ISO e CHX são distintos, avaliamos o efeito do tratamento conjunto dos dois fármacos. A CHX foi injetada e após $1 \mathrm{~h}$ os animais foram injetados com ISO (Fig. 3). Observando-se o gráfico pode-se verificar que também houve um aumento da quantidade de MDA, iniciando-se a partir de 20 min após a injeção de ISO (20 min, 26\%; 30 min, 22\%; 60 min, 8\%). 


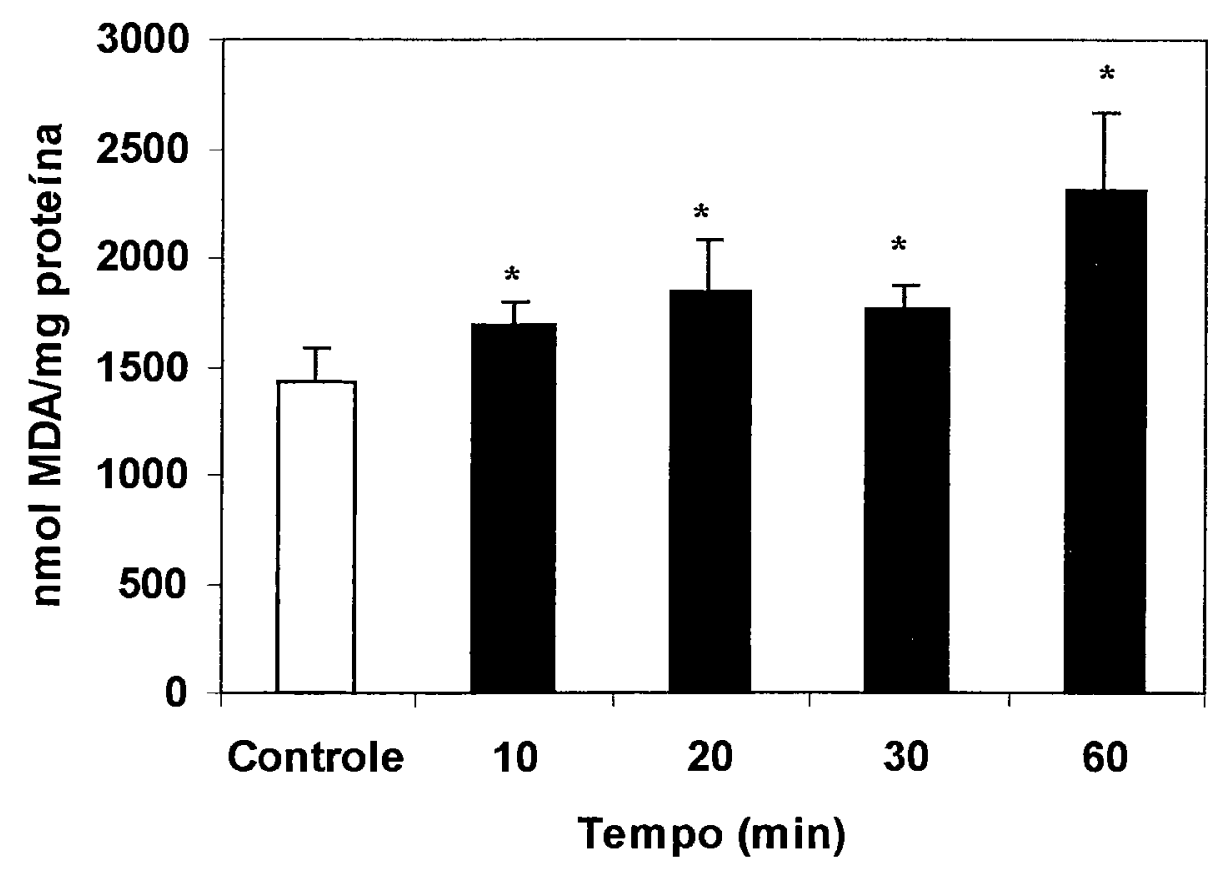

Fig. 1. Nível de MDA em glândulas submandibulares de ratos tratados com ISO. Os animais foram tratados com ISO (50 mg/kg) e as glândulas foram removidas em 10, 20, 30 e 60 min. O grupo controle foi tratado com $\mathrm{NaCl} \mathrm{0,9 \% .} \mathrm{*} \mathrm{As} \mathrm{diferenças}$ entre 0 grupo tratado e o grupo controle são estatisticamente significantes $(p<0,05), n=3$. 


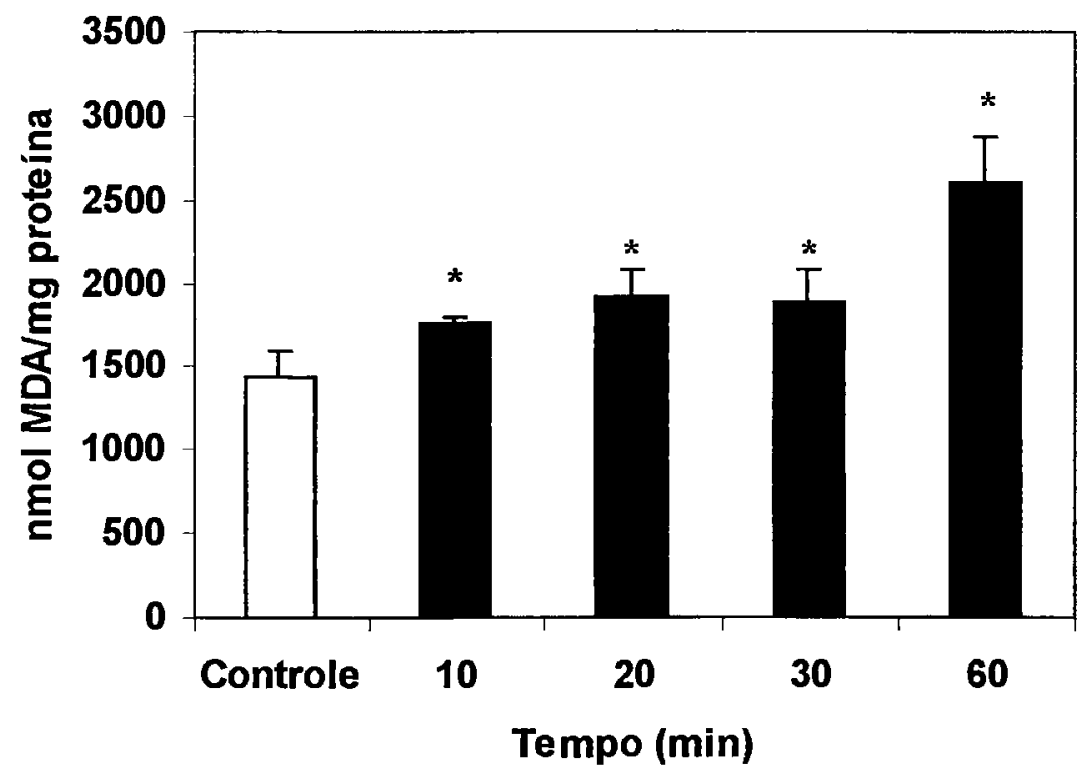

Fig. 2. Nível de MDA em glândulas submandibulares de ratos tratados com CHX. Os animais foram tratados com $\mathrm{CHX}$ (50 $\mathrm{mg} / \mathrm{kg}$ ) e as glândulas foram removidas em 10, 20, 30 e $60 \mathrm{~min} .0$ grupo controle foi tratado com $\mathrm{NaCl}$ 0,9\%. * As diferenças entre o grupo tratado e o grupo controle são estatisticamente significantes $(p<0,05), n=3$. 


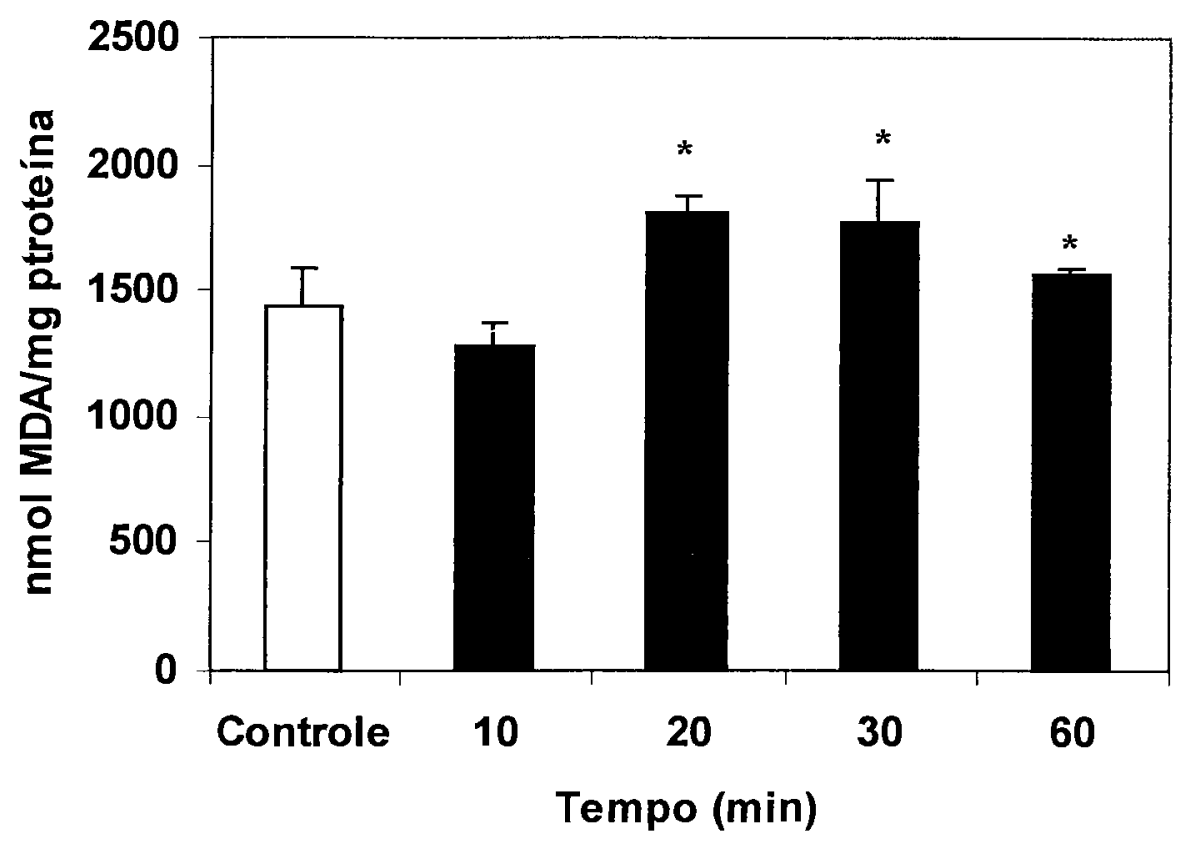

Fig. 3. Nível de MDA em glândulas submandibulares de ratos tratados com CHX e ISO. Os animais foram tratados com $\mathrm{CHX}(50 \mathrm{mg} / \mathrm{kg}$ ) por $1 \mathrm{~h}$ e em seguida injetados com ISO (50 $\mathrm{mg} / \mathrm{kg}$ ). As glândulas foram removidas em 10, 20, 30 e $60 \mathrm{~min}$ após o tratamento com ISO. O grupo controle foi tratado com $\mathrm{NaCl}$ 0,9\%. * As diferenças entre o grupo tratado e o grupo controle são estatisticamente significantes $(p<0,05), n=3$. 


\subsection{Níveis de MDA produzidos por tratamentos em}

\section{cultura de células dispersas.}

A cultura de células dispersas tem sido muito utilizada como modelo de estudo de secreção salivar. Assim como realizado in vivo, procedemos da mesma forma em cultura de células. O nível de $\mathrm{MDA} / \mathrm{mg}$ de proteína observado in vivo após o tratamento com ISO, $\mathrm{CHX}$ e $\mathrm{CHX}+\mathrm{ISO}$ foi comparado ao efeito dos mesmos fármacos no produzido in vitro. Os níveis de MDA em cultura de células acinares purificadas de glândulas submandibulares foram medidos após a incubação com ISO e CHX (Grupo I e II do item 3.5.1).

A figura 4 mostra um gráfico que indica o nível de MDA produzido por miligrama de proteína. Um aumento significativo foi observado aos 60 min de exposição ao ISO (60\%), enquanto níveis semelhantes ao controle foram observados após 10, 20 e 30 min de tratamento.

Entretanto, as culturas de células expostas a $\mathrm{CHX}$ apresentaram um nível de MDA significativamente maior do que o grupo controle em 10, 20 e 60 min após a incubação (10 $\min , 40 \% ; 20 \min 33 \%$ e 60 min, 86\%) (Fig. 5).

Resultados semelhantes aos obtidos após incubação com ISO foram encontrados em culturas de células pré-incubadas com $\mathrm{CHX}$ por $30 \mathrm{~min}$, seguida de incubação com ISO por 10, 20, 30 e 60 min (Grupo III do item 3.5.1.). Nestas células, o nível de MDA foi significativamente maior ( $81 \%$ ) do que o grupo controle após 60 min de incubação com ISO, enquanto que sob o mesmo tratamento, não foi observada alteração no nível de MDA aos 10, 20 e 30 min após incubação (Fig. 6). 


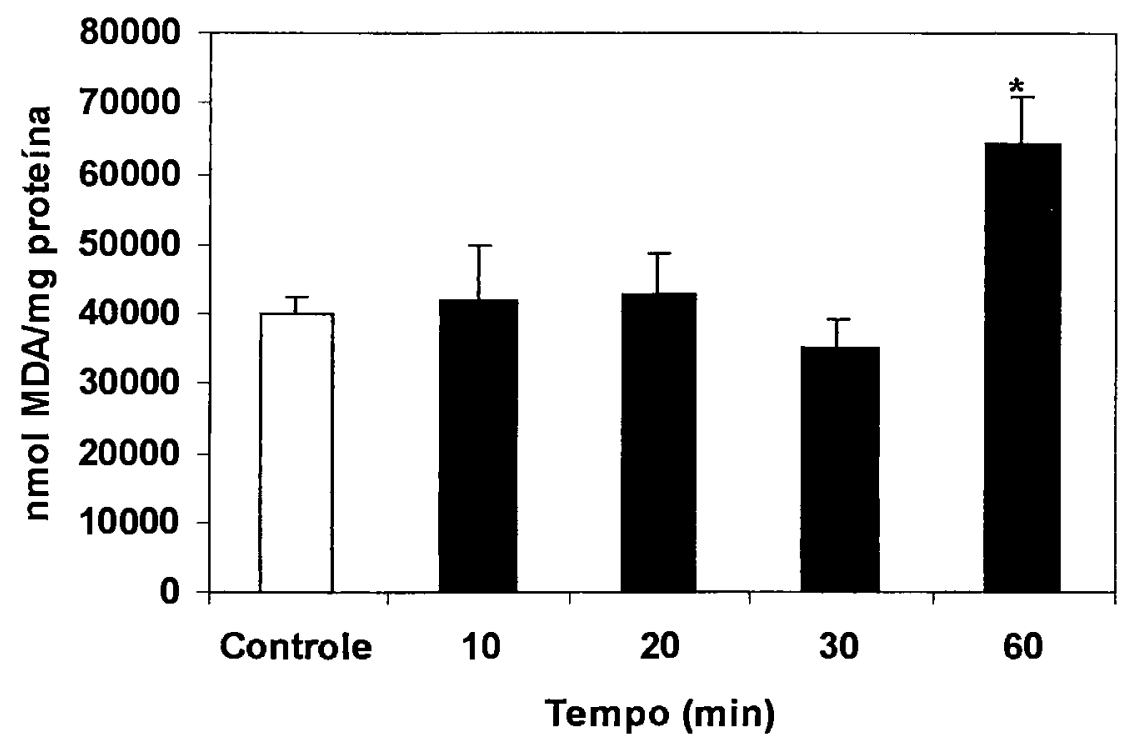

Fig. 4. Nível de MDA em células dispersas de glândulas submandibulares de ratos expostas ao ISO. A cultura de células foi tratada com ISO $(10 \mu \mathrm{M})$ por $10,20,30$ e $60 \mathrm{~min}$. 0 grupo controle foi tratado com $\mathrm{NaCl} 0,9 \%$. * As diferenças entre o grupo tratado e o grupo contrale são estatisticamente significantes $(p<0,05), n=3$. 


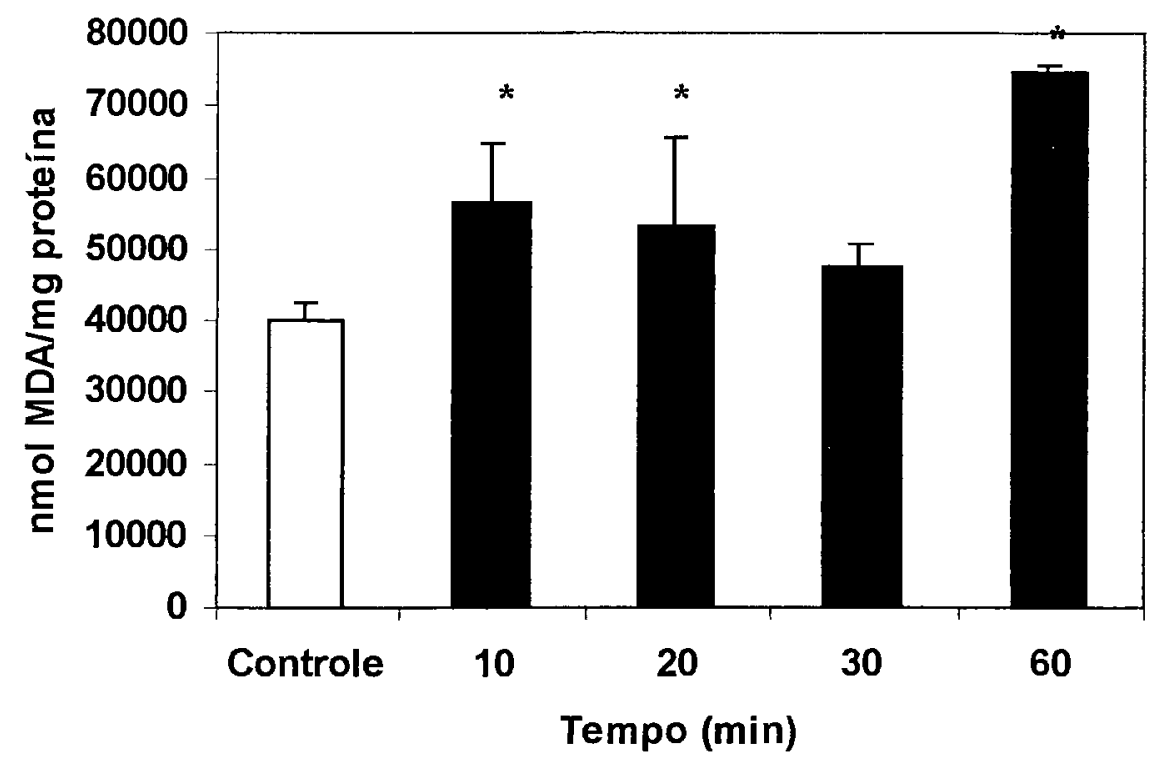

Fig. 5. Nível de MDA em células dispersas de glândulas submandibulares de ratos expostas à $\mathbf{C H X}$. A cultura de células foi tratada com $\mathrm{CHX}(10 \mathrm{mg} / \mathrm{mL})$ por $10,20,30$ e $60 \mathrm{~min}$. O grupo controle foi tratado com $\mathrm{NaCl} 0,9 \%$ * As diferenças entre o grupo tratado e o grupo controle são estatisticamente significantes $(p<0,05), n=3$. 


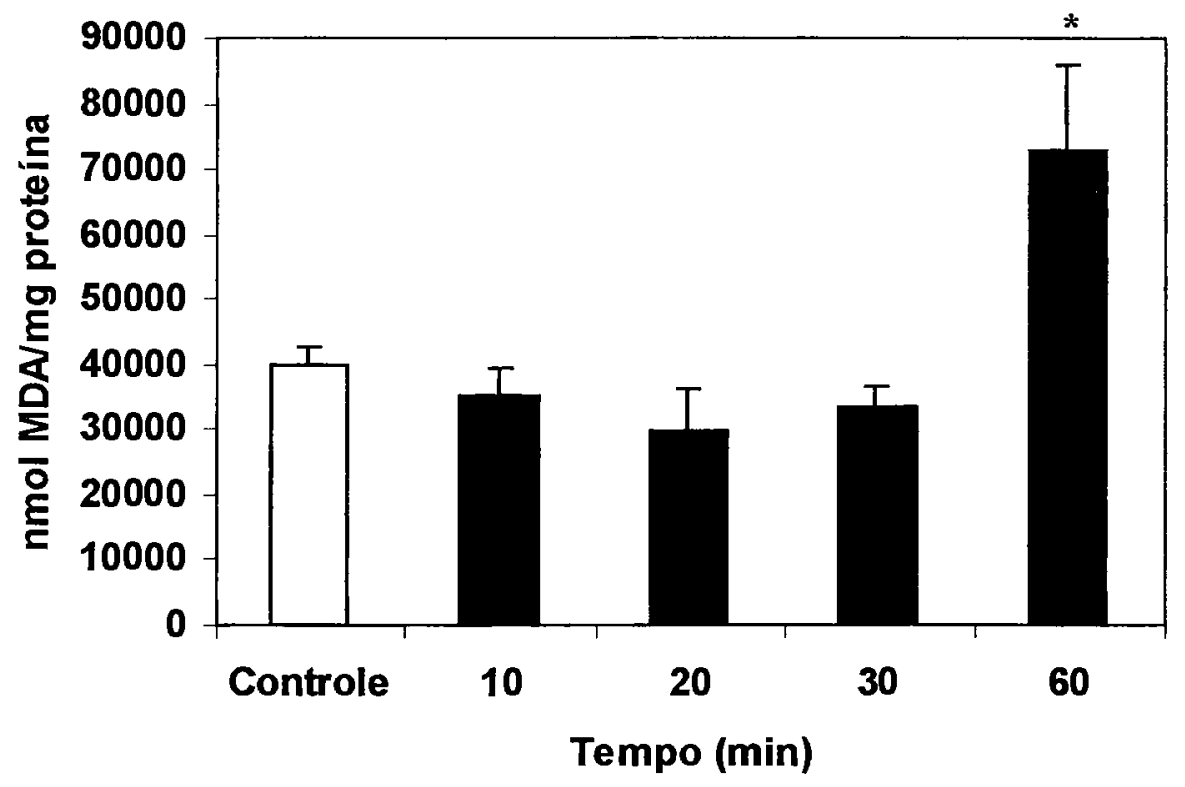

Fig. 6. Nível de MDA em células dispersas de glândulas submandibulares de ratos expostas à $\mathrm{CHX}$ e ISO. A cultura de células foi tratada com $\mathrm{CHX}(10 \mathrm{mg} / \mathrm{mL})$ por 30 min seguido de ISO $(10 \mu \mathrm{M})$ por $10,20,30$ e $60 \mathrm{~min}$. O grupo controle foi tratado com $\mathrm{NaCl} 0,9 \%$. * As diferenças entre o grupo tratado e o grupo controle são estatisticamente significantes $(p<0,05), n=3$. 


\subsection{Oxidação de proteínas in vivo.}

Os efeitos oxidativos produzidos em proteínas foram estimados in vivo, a partir da medida do conteúdo de carbonilas protéicas produzidas em glândulas submandibulares durante os tratamentos in vivo com ISO $(50 \mathrm{mg} / \mathrm{Kg})$ e $\mathrm{CHX}(50$ $\mathrm{mg} / \mathrm{Kg}$ ) descritos anteriormente.

A figura 7 mostra o gráfico da variação na quantidade de carbonilas protéicas por miligrama de proteína. Em tratamentos agudos com ISO foi verificada uma redução após 10 e 30 min de tratamento (15 e 26\% respectivamente). Aos 60 min de incubação os níveis de carbonilas protéicas retornam aos mesmos patamares do controle.

Quando a CHX foi injetada não houve alteração na produção de carbonilas protéicas como pode ser observado na fig. 8. As mesmas dosagens foram realizadas nos experimentos de pré-tratamento com $\mathrm{CHX}$ por $1 \mathrm{~h}$, seguido de injeção com ISO e houve uma redução na produção de carbonilas protéicas em 10 min (33\%), enquanto após 20, 30 e 60 min de tratamento houve um retorno da quantidade de carbonilas em relação ao grupo controle (Fig. 9). 


\subsection{Oxidação de proteínas em células dispersas.}

Os ensaios de oxidação protéica observados in vivo também foram comparados aos encontrados in vitro. Experimentos de incubação de células dispersas com ISO $(10 \mu \mathrm{M})$ e $\mathrm{CHX}(10 \mathrm{mg} / \mathrm{mL})$ por 10,20 , 30 e 60 min foram realizados. Os valores de carbonilas produzidas durante a incubação mostram um aumento em 20 min após exposição a ISO (38\%) (Fig. 10). Na incubação com CHX também se observou um aumento de 5, 19 e 19\% após 10, 20 e 60 min respectivamente (Fig. 11). O resultado da quantidade de carbonilas produzidas durante a pré-incubação das culturas de células tratadas com $\mathrm{CHX}$, seguida da incubação com ISO está mostrado na figura 12. Os resultados mostram um aumento significativo após exposição ao ISO (10 min, 63\% e 60 min, 84\%). 


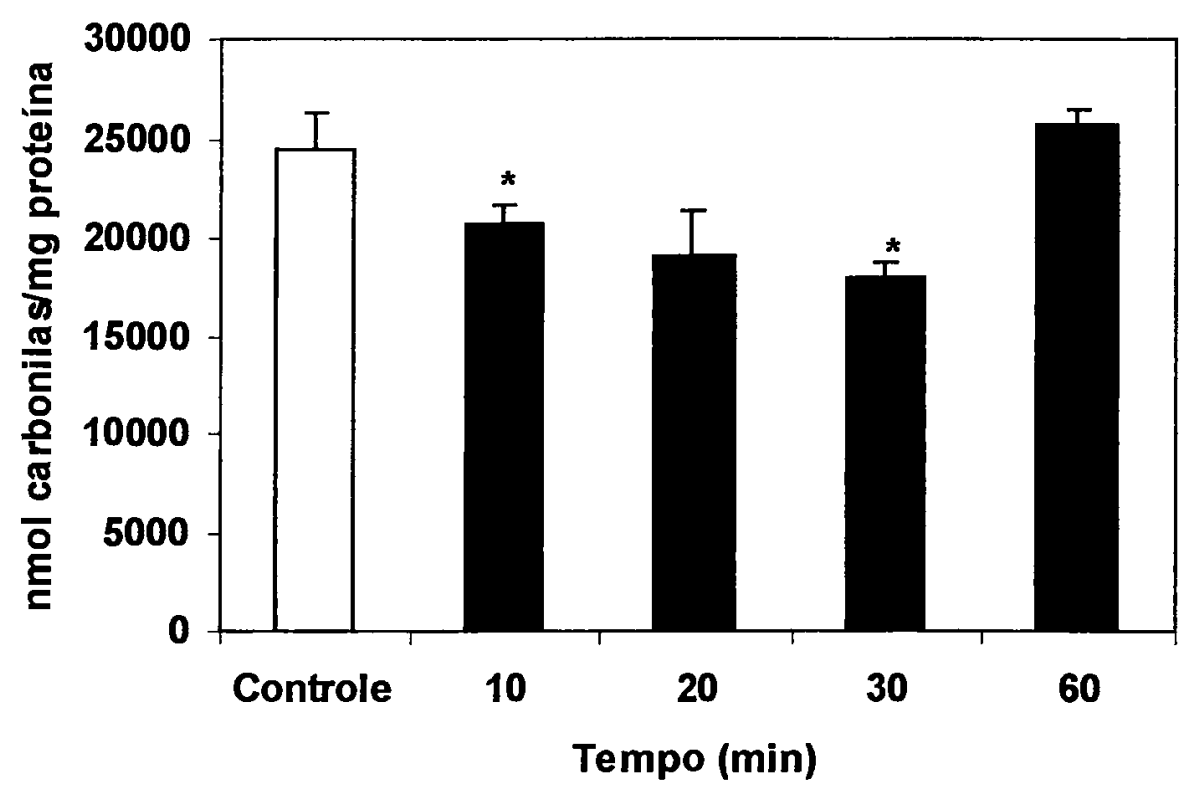

Fig. 7. Oxidação protéica em glândulas submandibulares de ratos tratados com ISO. Os animais foram tratados com ISO (50 mg/kg). As glândulas foram removidas em 10, 20, 30 e 60 min após o tratamento com ISO. O grupo controle foi tratado com $\mathrm{NaCl}$ 0,9\%. * As diferenças entre o grupo tratado e o grupo controle são estatisticamente significantes $(p<0,05), n=3$. 


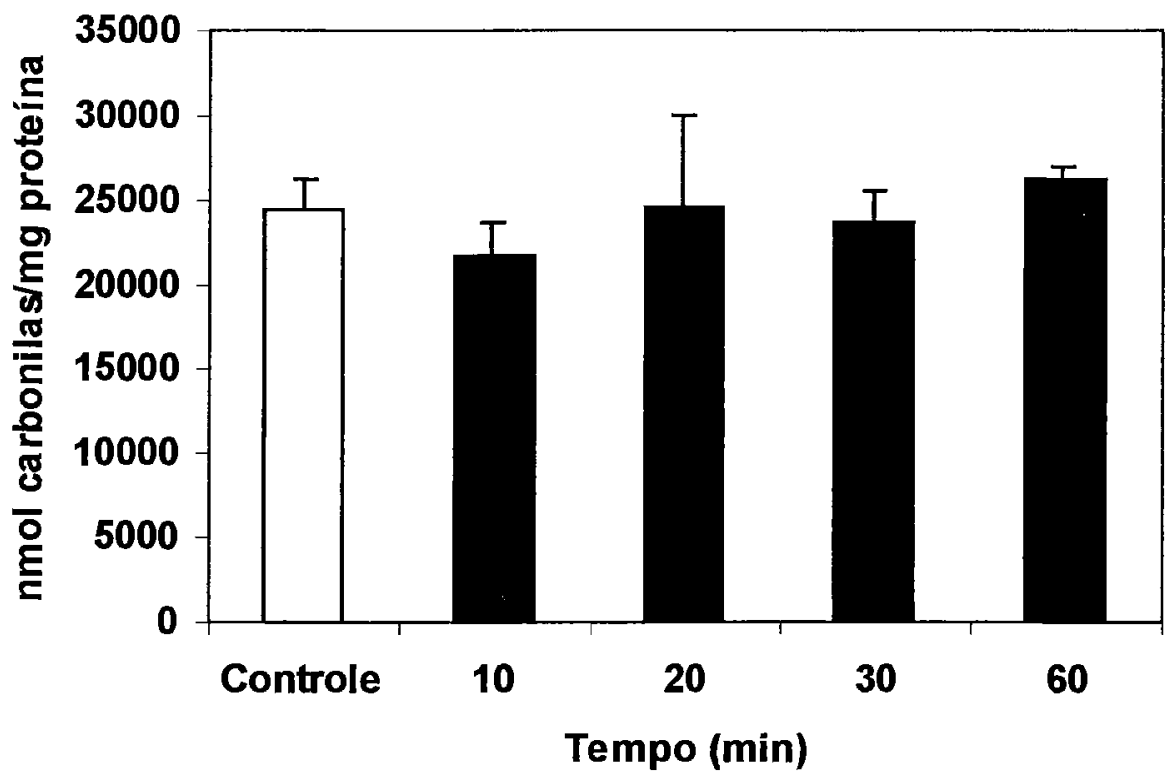

Fig. 8. Oxidação protéica em glândulas submandibulares de ratos tratados com $\mathbf{C H X}$. Os animais $(n=3)$ foram tratados com $\mathrm{CHX}(50 \mathrm{mg} / \mathrm{kg}$ ) e as glândulas foram removidas em 10, 20, 30 e 60 min após o tratamento. O grupo controle foi tratado com $\mathrm{NaCl}$ $0,9 \%$. 


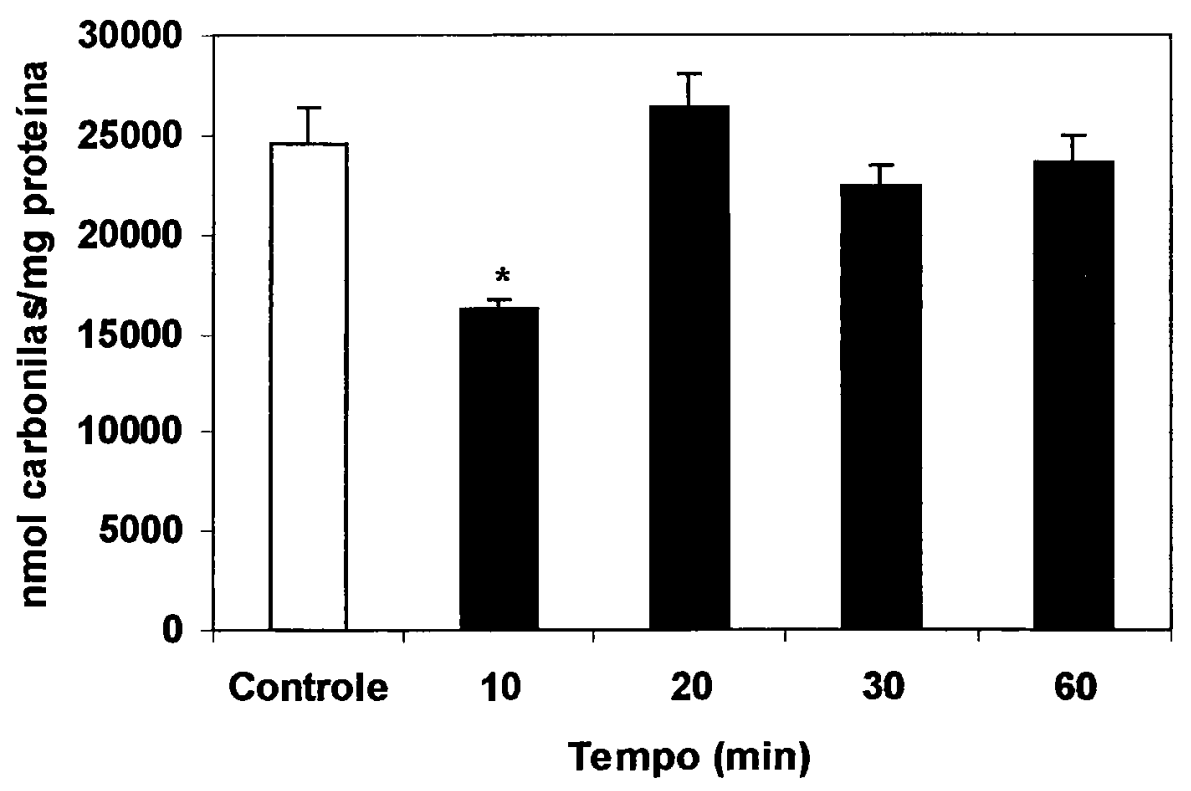

Fig. 9. Oxidação de proteínas em glândulas submandibulares de ratos tratados com $\mathrm{CHX}$ e ISO. Os animais foram tratados com $\mathrm{CHX}(50 \mathrm{mg} / \mathrm{kg})$ por $1 \mathrm{~h}$ e em seguida injetados com ISO (50 mg/kg). As glândulas foram removidas em $10,20,30$ e 60 min após o tratamento com ISO. O grupo controle foi tratado com $\mathrm{NaCl} 0,9 \%$. * As diferenças entre o grupo tratado e o grupo controle são estatisticamente significantes $(p<0,05)$, $n=3$. 


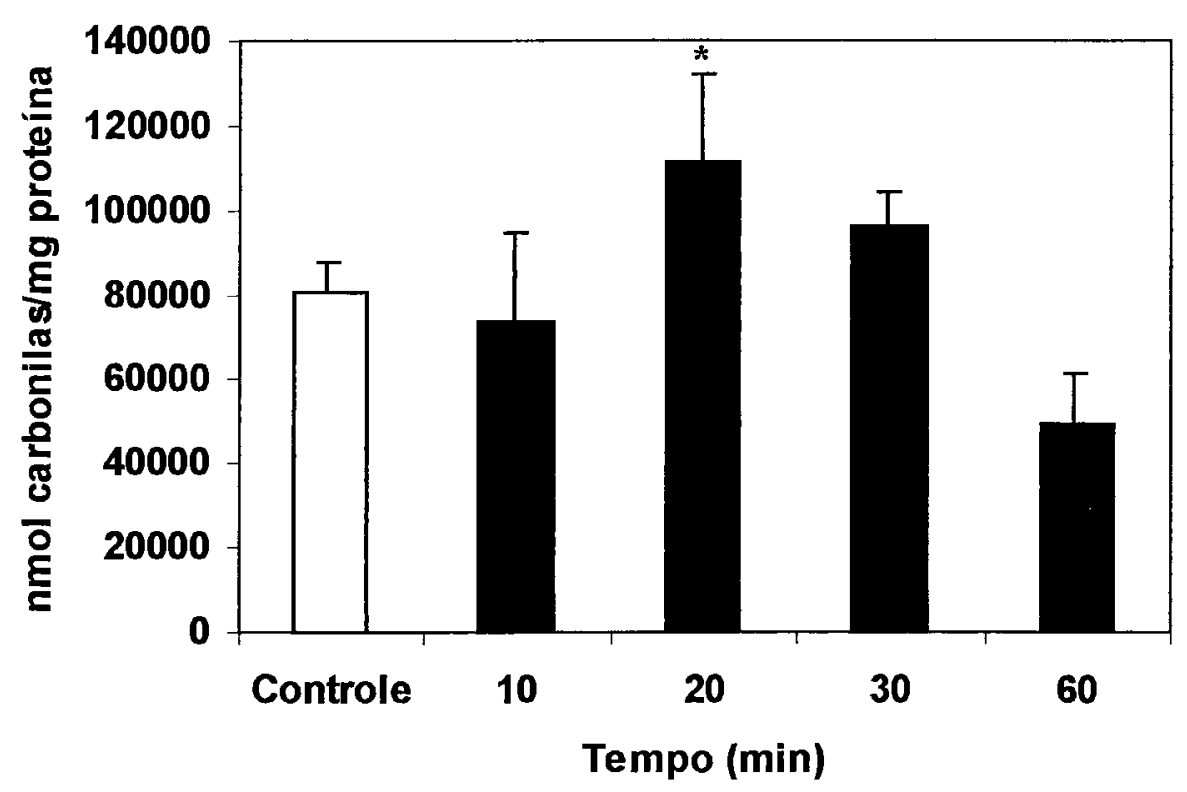

Fig. 10. Oxidação protéica em células dispersas de glândulas submandibulares de ratos expostas ao ISO. A cultura de células foi tratada com ISO $(10 \mu \mathrm{M})$ por $10,20,30$ e 60 min. $\mathrm{O}$ grupo controle foi tratado com $\mathrm{NaCl} 0,9 \%$ * As diferenças entre o grupo tratado e o grupo controle são estatisticamente significantes $(p<0,05), n=3$. 


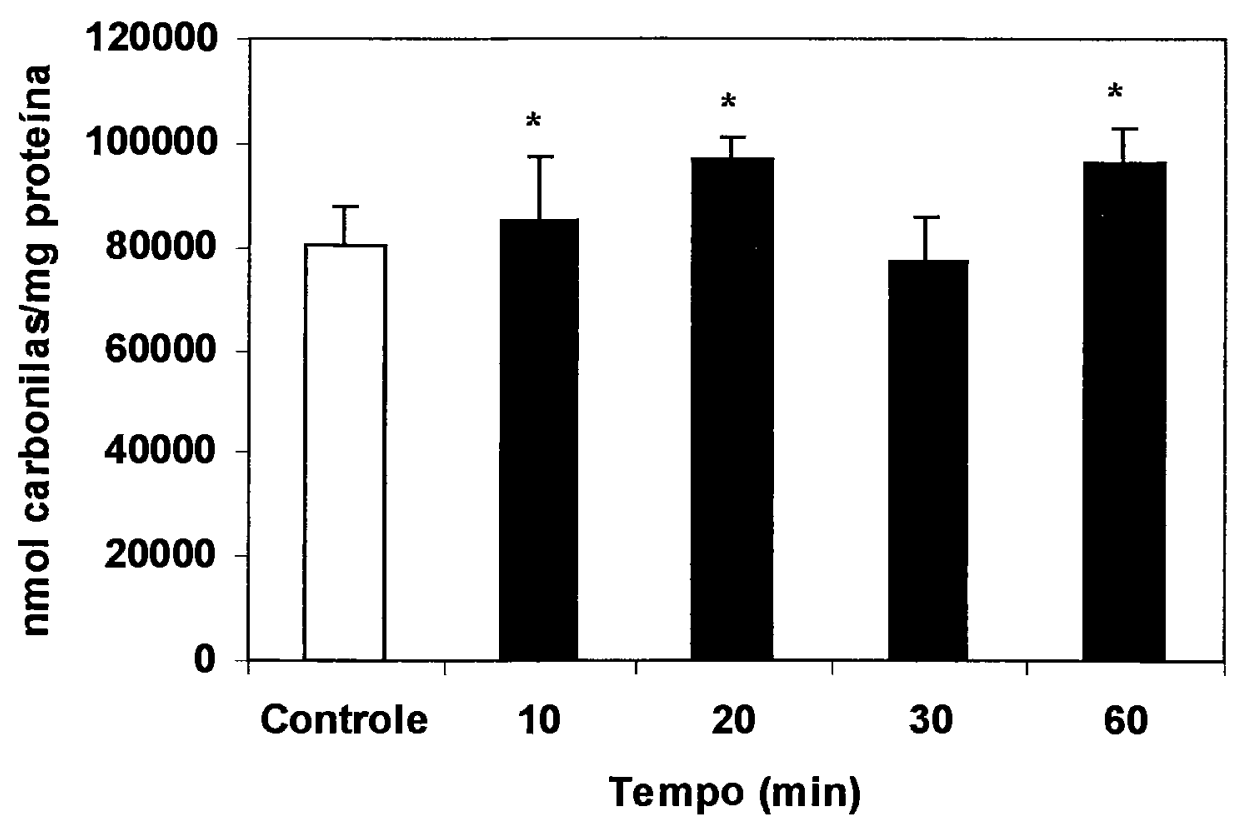

Fig. 11. Oxidação protéica em células dispersas de glândulas submandibulares de ratos expostas à CHX. A cultura de células foi tratada com $\mathrm{CHX}(10 \mathrm{mg} / \mathrm{mL})$ por $10,20,30$ e 60 min. 0 grupo controle foi tratado com $\mathrm{NaCl} 0,9 \%$. * As diferenças entre o grupo tratado e o grupo controle são estatisticamente significantes $(p<0,05), n=3$. 


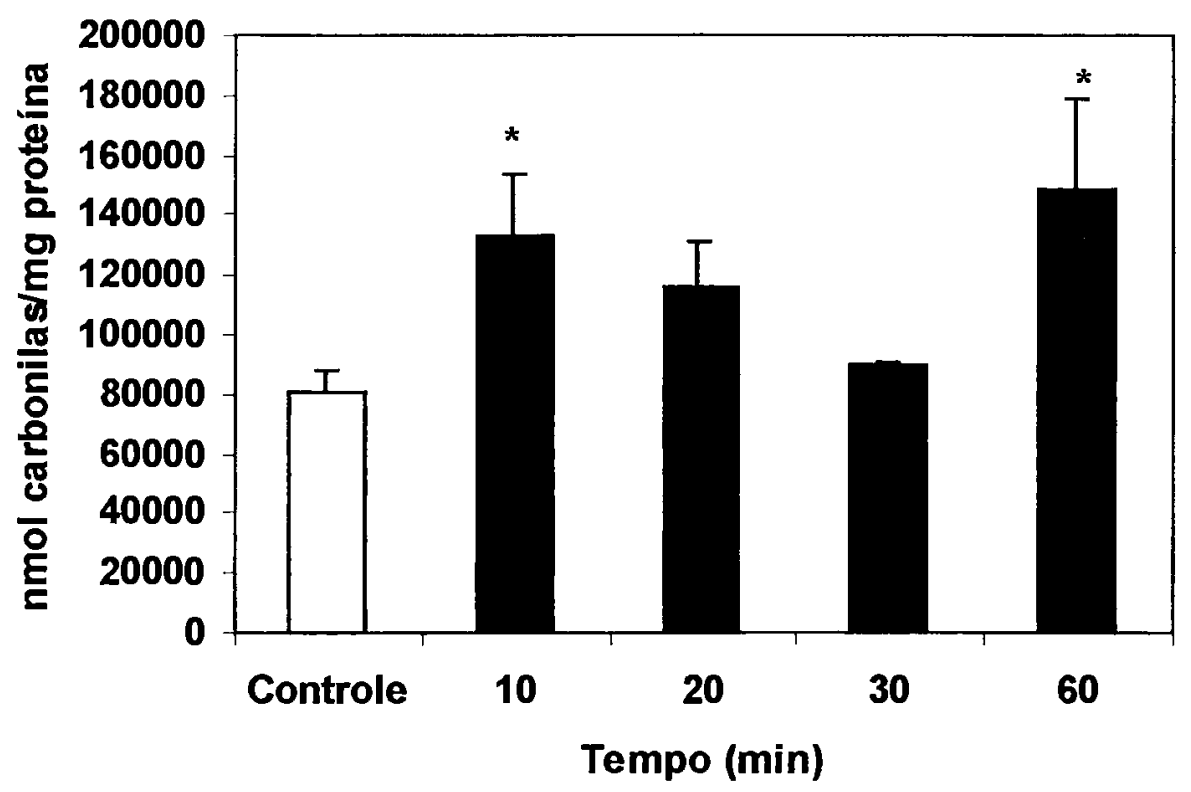

Fig. 12. Oxidação protéica em células dispersas de glândulas submandibulares de ratos expostas à $\mathrm{CHX}$ e ISO. A cultura de células foi tratada com $\mathrm{CHX}(10 \mathrm{mg} / \mathrm{mL})$ por 30 min seguido de ISO $(10 \mu \mathrm{M})$ por $10,20,30$ e $60 \mathrm{~min}$. O grupo controle foi tratado com $\mathrm{NaCl}$ 0,9\%. * As diferenças entre o grupo tratado e o grupo controle são estatisticamente significantes $(p<0,05), n=3$. 


\subsection{Poder redutor após tratamentos in vivo.}

As glândulas salivares e as células acinares respondem de forma diferente aos tratamentos com ISO e CHX em relação à produção de MDA e à oxidação protéica. Com isso a indução de antioxidantes também pode variar. Um dos parâmetros de avaliação de antioxidantes utilizado neste trabalho foi a medida do conteúdo de GSH.

A figura 13 mostra o poder redutor após o tratamento in vivo com ISO. Um aumento no poder redutor foi observado em $10 \mathrm{~min}(11 \%), 20 \mathrm{~min}(48 \%), 30 \mathrm{~min}$ (108\%) e 60 min (70\%). Contudo, em condições semelhantes, mas utilizando CHX no tratamento dos animais, foi observada uma redução do poder redutor, ou seja, uma situação pró-oxidante. Esta redução observada foi significante aos $10 \mathrm{~min}$ (21\%), $20 \mathrm{~min}(40 \%), 30 \mathrm{~min}(38 \%)$ e $60 \mathrm{~min}$ (19\%) (Fig. 14). No entanto, no tratamento com ambos $\mathrm{CHX}$ e ISO, foi observado um aumento no poder redutor aos 60 min após o tratamento de ISO (85\%), enquanto após 10,20 e 30 min do tratamento o poder redutor foi semelhante ao controle (Fig. 15).

Em células dispersas, a incubação com ISO provocou aumento na capacidade antioxidante medida por meio do aumento no poder redutor após $20 \mathrm{~min}(24 \%)$ e 30 min (49\%), porém verificou-se uma redução no poder redutor após 60 min (31\%), indicando uma condição pró-oxidante (Fig. 16).

Na incubação de células dispersas com CHX e CHX seguido de ISO (Grupo II e III do item 3.5.1.) não se observou alteração significativa no poder redutor (Fig. $17 \mathrm{e}$ 18). 


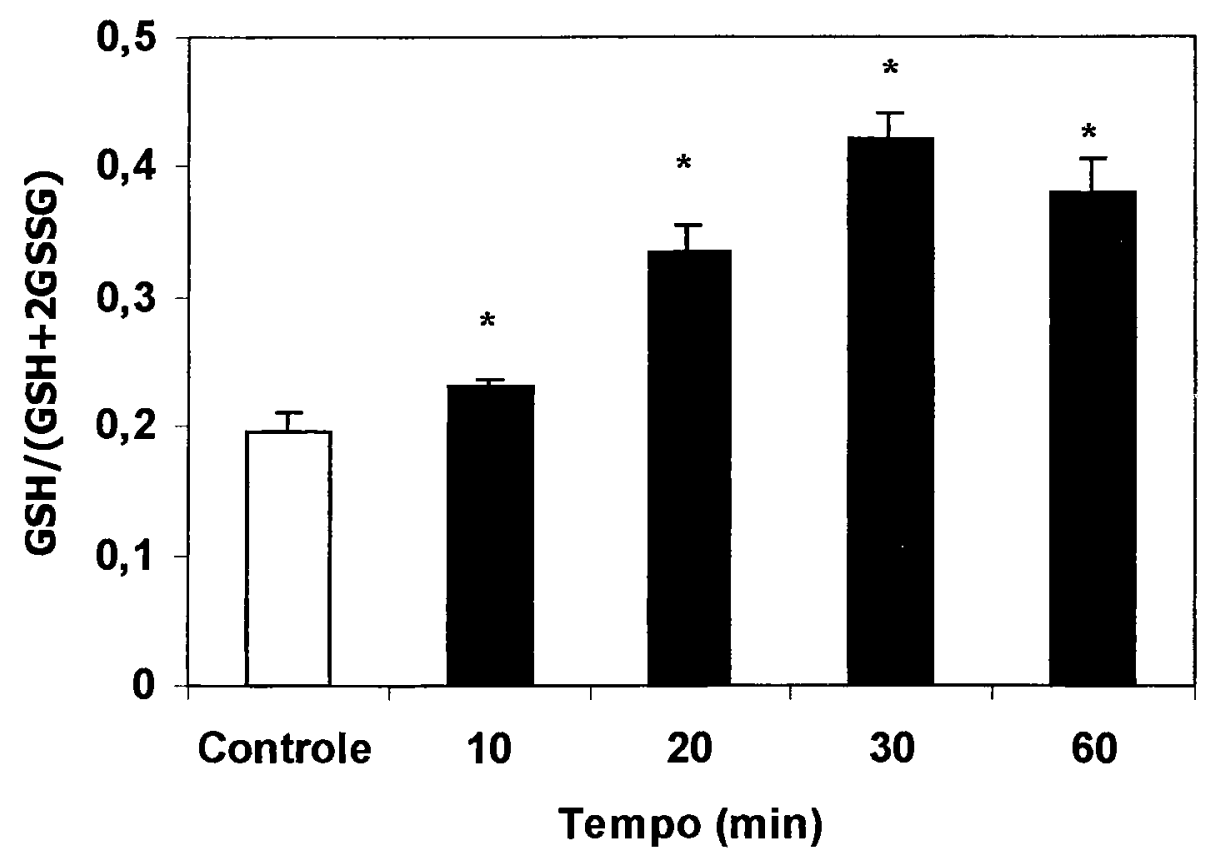

Fig. 13. Poder redutor em glândulas submandibulares de ratos tratados com ISO. Os animais foram tratados com ISO (50 mg/kg) e as glândulas foram removidas em 10, 20, 30 e 60 min após o tratamento. O grupo controle foi tratado com $\mathrm{NaCl}$ 0,9\%. Os resultados estão apresentados como conteúdo de glutationa reduzida em relação à glutationa total (reduzida e oxidada). * As diferenças entre o grupo tratado e o grupo controle são estatisticamente significantes $(p<0,05), n=3$. 


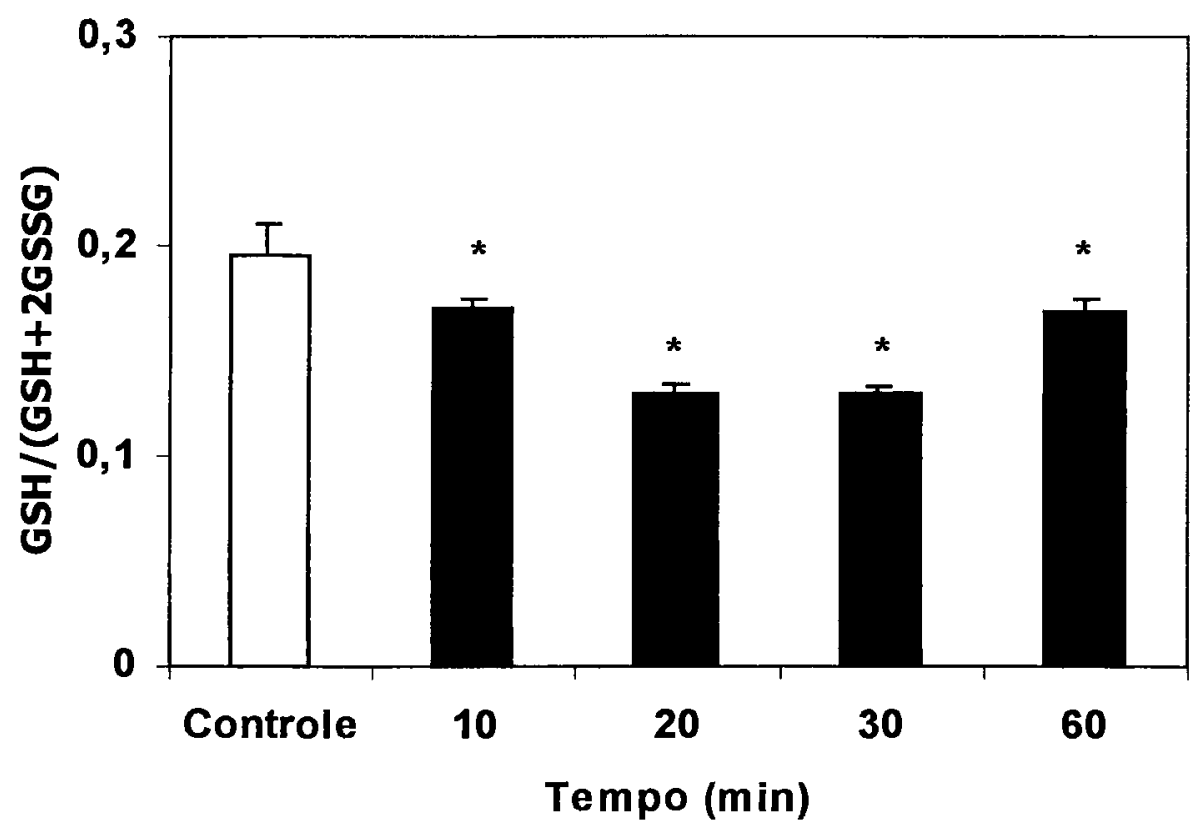

Fig. 14. Poder redutor em glândulas submandibulares de ratos tratados com CHX. Os animais foram tratados com $\mathrm{CHX}$ (50 mg/kg) e as glândulas foram removidas em 10, 20, 30 e 60 min após o tratamento. O grupo controle foi tratado com $\mathrm{NaCl}$ $0,9 \%$. Os resultados estão apresentados como conteúdo de glutationa reduzida em relação à glutationa total (reduzida e oxidada). * As diferenças entre o grupo tratado e o grupo controle são estatisticamente significantes $(p<0,05), n=3$. 


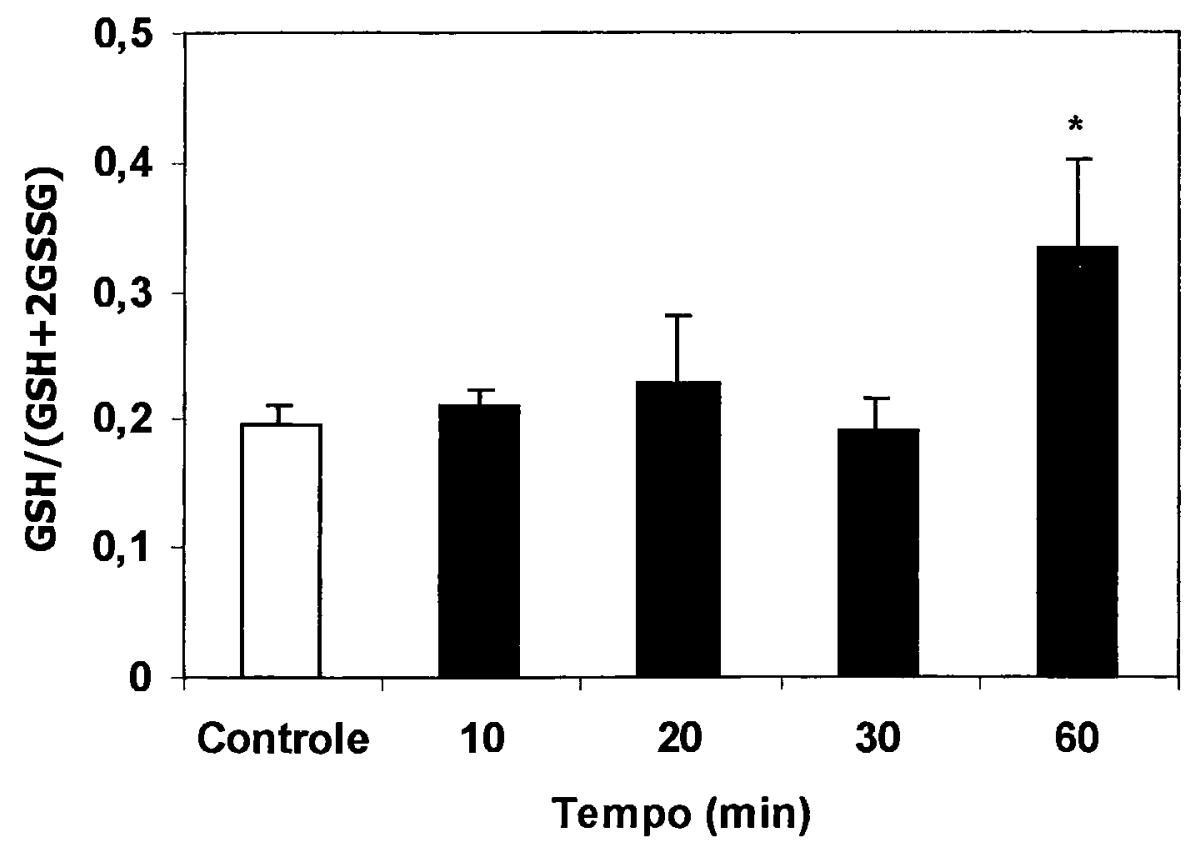

Fig. 15. Poder redutor em glândulas submandibulares de ratos tratados com $\mathrm{CHX}$ e ISO. Os animais foram tratados com CHX (50 mg/kg) por $1 \mathrm{~h}$ e em seguida injetados com ISO (50 $\mathrm{mg} / \mathrm{kg}$ ). As glândulas foram removidas em 10, 20, 30 e 60 min após o tratamento com ISO. O grupo controle foi tratado com $\mathrm{NaCl}$ 0,9\%. Os resultados estão apresentados como conteúdo de glutationa reduzida em relação à glutationa total (reduzida e oxidada). * As diferenças entre o grupo tratado e o grupo controle são estatisticamente significantes $(p<0,05), n=3$. 


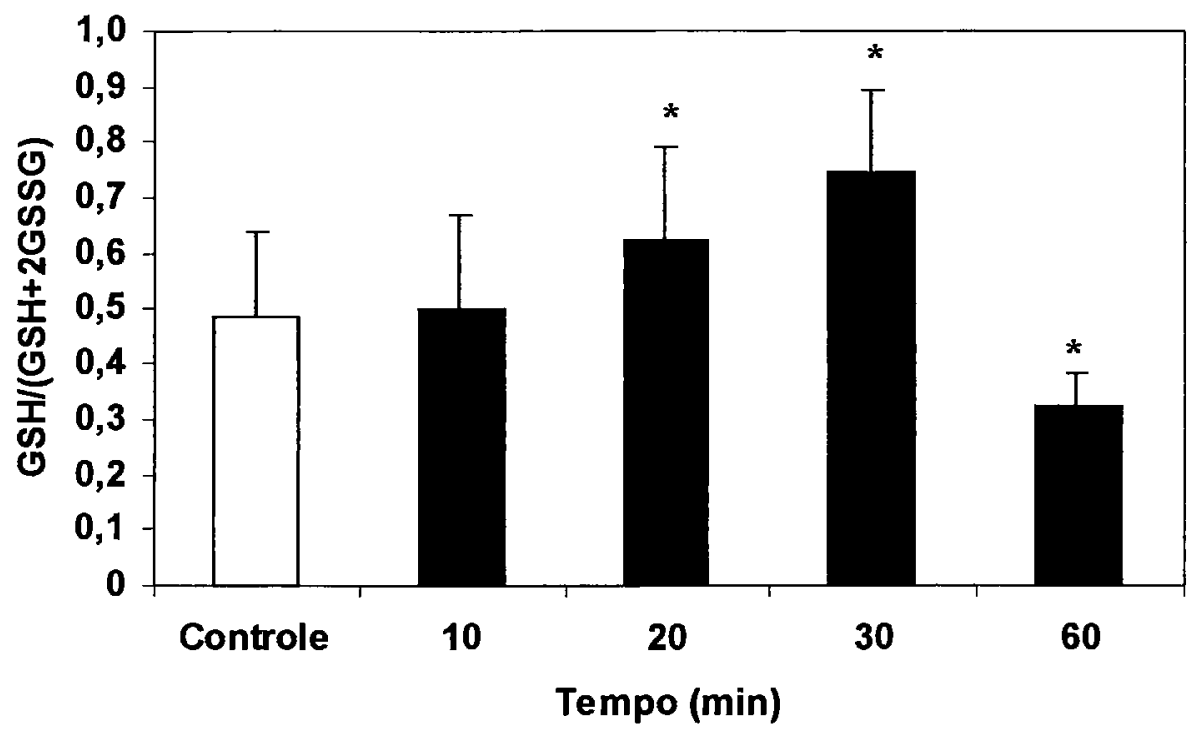

Fig. 16. Poder redutor em células dispersas de glândulas submandibulares de ratos expostas ao ISO. A cultura de células foi tratada com ISO $(10 \mu \mathrm{M})$ por $10,20,30$ e $60 \mathrm{~min}$. 0 grupo controle foi tratado com $\mathrm{NaCl} 0,9 \%$. Os resultados estão apresentados como conteúdo de glutationa reduzida em relação à glutationa total (reduzida e oxidada). * As diferenças entre o grupo tratado e o grupo controle são estatisticamente significantes $(p<0,05), n=3$. 


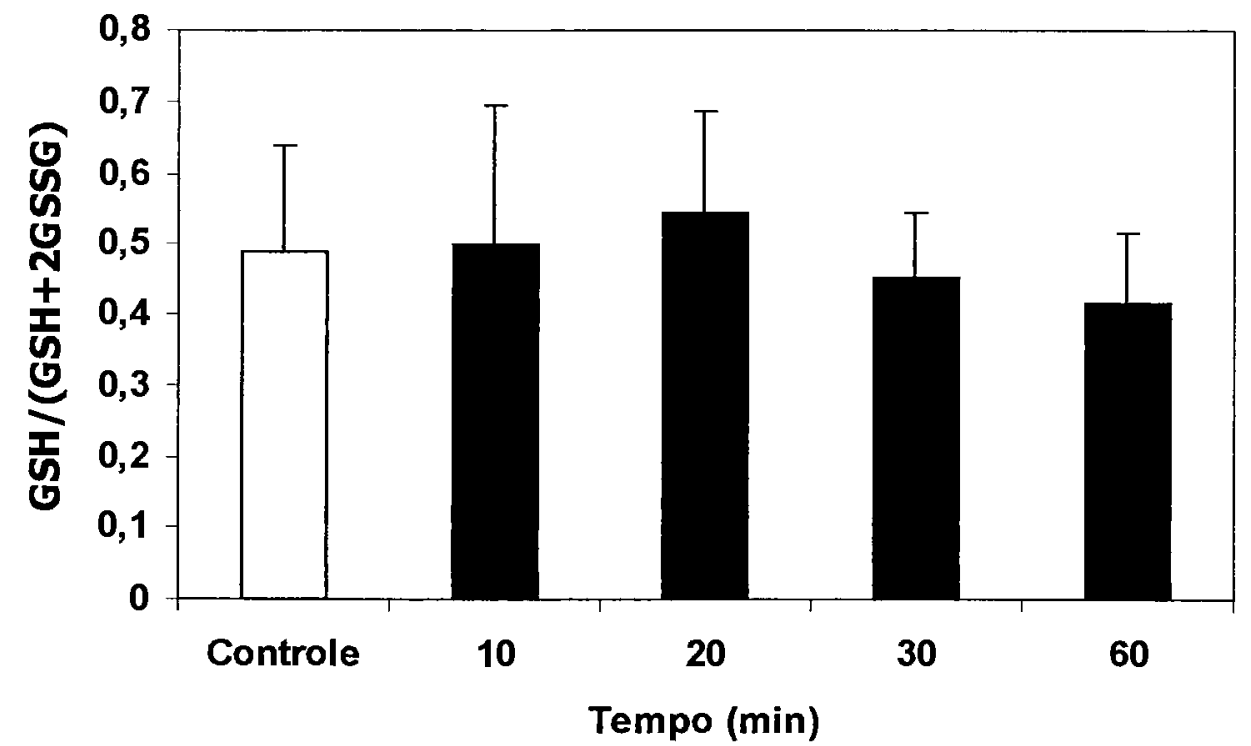

Fig. 17. Poder redutor em células dispersas de glândulas submandibulares de ratos expostas à $\mathbf{C H X}$. A cultura de células $(n=3)$ foi tratada com $\mathrm{CHX}(10 \mathrm{mg} / \mathrm{mL})$ por $10,20,30$ e 60 min. O grupo controle foi tratado com $\mathrm{NaCl} 0,9 \%$. Os resultados estão apresentados como conteúdo de glutationa reduzida em relação à glutationa total (reduzida e oxidada). 


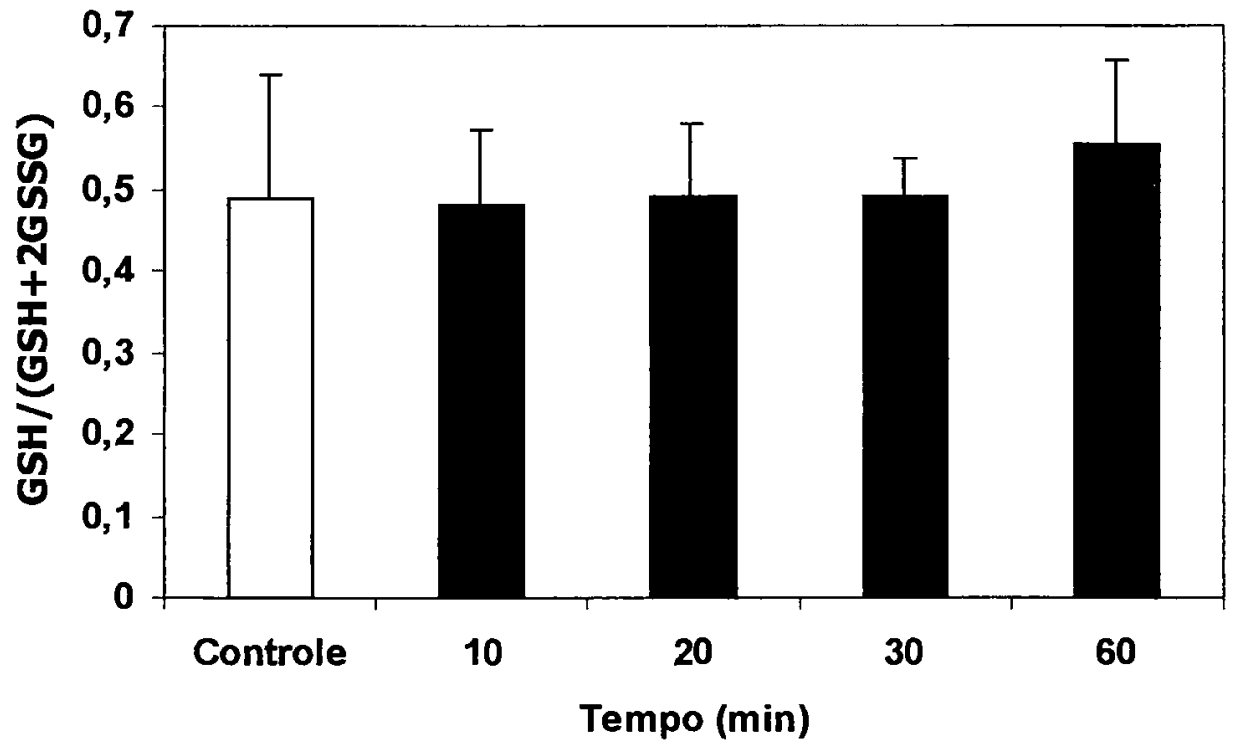

Fig. 18. Poder redutor em células dispersas de glândulas submandibulares de ratos expostas à $\mathrm{CHX}$ e ao ISO. A cultura de células $(n=3)$ foi tratada com $\mathrm{CHX}(10 \mathrm{mg} / \mathrm{mL})$ por 30

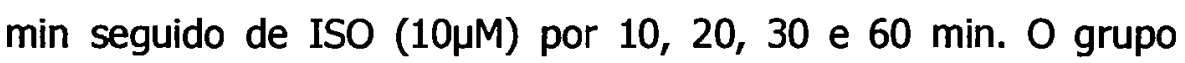
controle foi tratado com $\mathrm{NaCl} 0,9 \%$. 


\subsection{Padrão de atividade total de SOD em tratamentos in} vivo.

A enzima SOD, pouco estudada em glândulas salivares, é considerada a primeira linha de defesa antioxidante celular. Sendo uma enzima importante no processo de proteção antioxidante, seu mecanismo de ativação também é mediado por meio das vias de transdução de sinais intracelulares. Deste modo, neste trabalho verificou-se a resposta da atividade da enzima antioxidante SOD em glândulas submandibulares, após a ativação de receptores adrenérgicos e colinérgicos de membrana.

O tratamento agudo in vivo com CA não provocou aumento da atividade de SOD, revelando níveis de atividade da enzima semelhantes aos níveis do grupo tratado com solução salina (Fig. 19). Entretanto, após os tratamentos agudos com ISO, houve um aumento significativo na atividade de SOD (20 min, 55\%; $30 \mathrm{~min}$, $52 \%$ e 60 min, 63\%) (Fig. 20). No tratamento com CHX, foi observada uma redução da atividade total de SOD (20 min, 28\%, $30 \mathrm{~min}, 46 \%$ e $60 \mathrm{~min}, 55 \%$ ) (Fig. 21). A Tabela 1 resume os dados obtidos nos tratamentos in vivo com ISO e $\mathrm{CHX}$.

A figura 22 mostra a atividade de SOD após o tratamento com $\mathrm{CHX}$ e $\mathrm{CHX}+$ ISO. O tratamento com $\mathrm{CHX}$ por $1 \mathrm{~h}$ provocou uma redução da atividade enzimática em $62 \%$. Quando foi injetado ISO após um pré-tratamento com $\mathrm{CHX}$ por $1 \mathrm{~h}$, os animais tratados com ISO mostram a atividade de SOD com valores semelhantes ao do grupo controle. A Tabela 2 resume os dados obtidos nos tratamentos com $\mathrm{CHX} 1$ h, seguido de ISO. 
Para testar a hipótese de que o aumento da atividade de SOD é dependente da existência da célula intacta sob condições normais, verificou-se a ação direta de ISO no homogenado. A figura 23 revela que ISO, CA e CHX não tem efeito na variação da atividade de SOD no homogenado, uma vez que a atividade de SOD após a incubação foi semelhante a valores encontrados no grupo controle, que foi tratado com $\mathrm{NaCl} 0,9 \%$. 


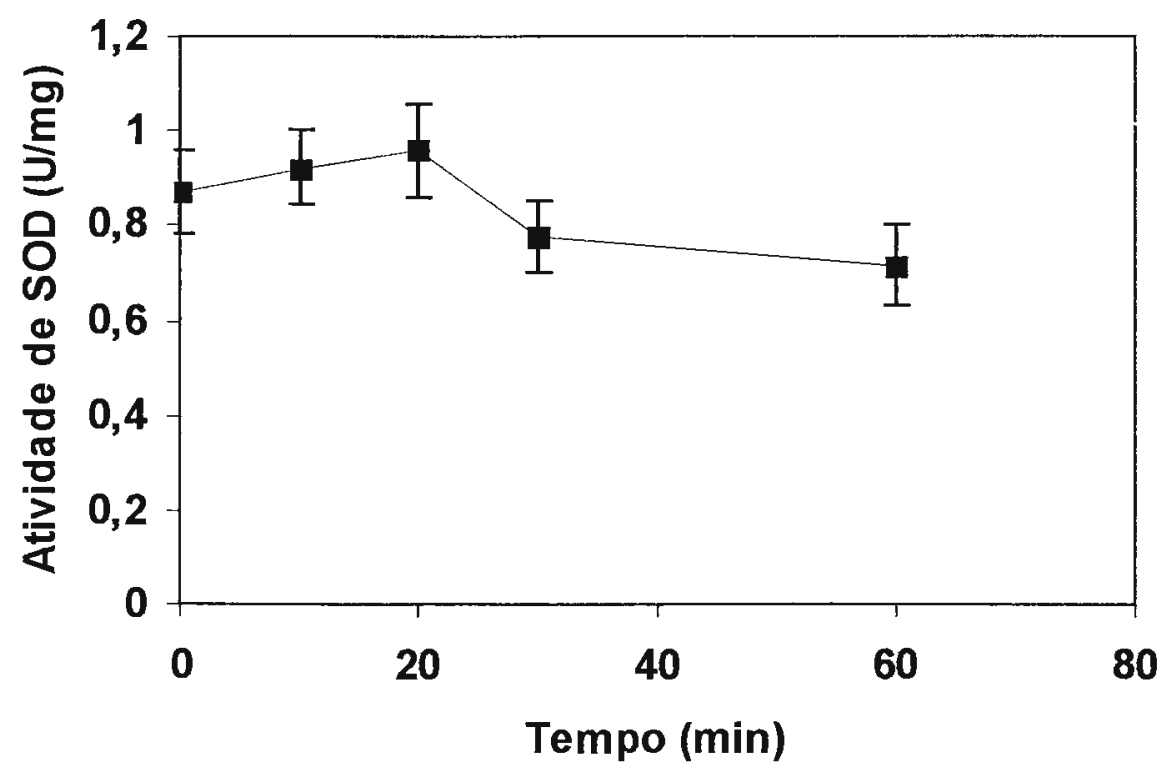

Fig. 19. Atividade total de SOD em glândulas submandibulares de ratos tratados com CA. Os animais foram tratados com $\mathrm{CA}(0,3 \mathrm{mg} / \mathrm{kg})$ e as glândulas foram removidas em 10, 20, 30 e 60 min após o tratamento. O grupo controle foi tratado com $\mathrm{NaCl} 0,9 \%$. * As diferenças entre o grupo tratado e o grupo controle são estatisticamente significantes $(p<0,05)$ 


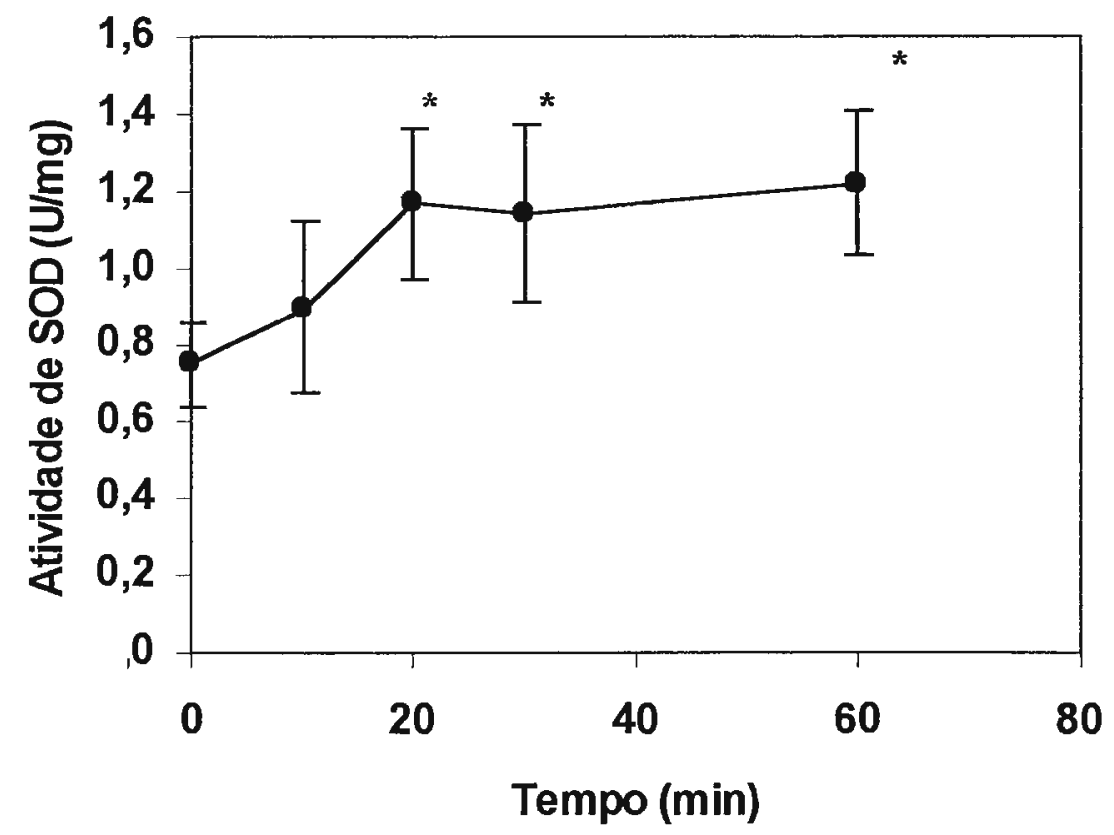

Fig. 20. Atividade total de SOD em glândulas submandibulares de ratos tratados com ISO. Os animais foram tratados com ISO (50 mg/kg) e as glândulas foram removidas em 10, 20, 30 e 60 min após o tratamento. O grupo controle foi tratado com $\mathrm{NaCl} 0,9 \%$. * As diferenças entre o grupo tratado e o grupo controle são estatisticamente significantes $(p<0,05), n=3$. 


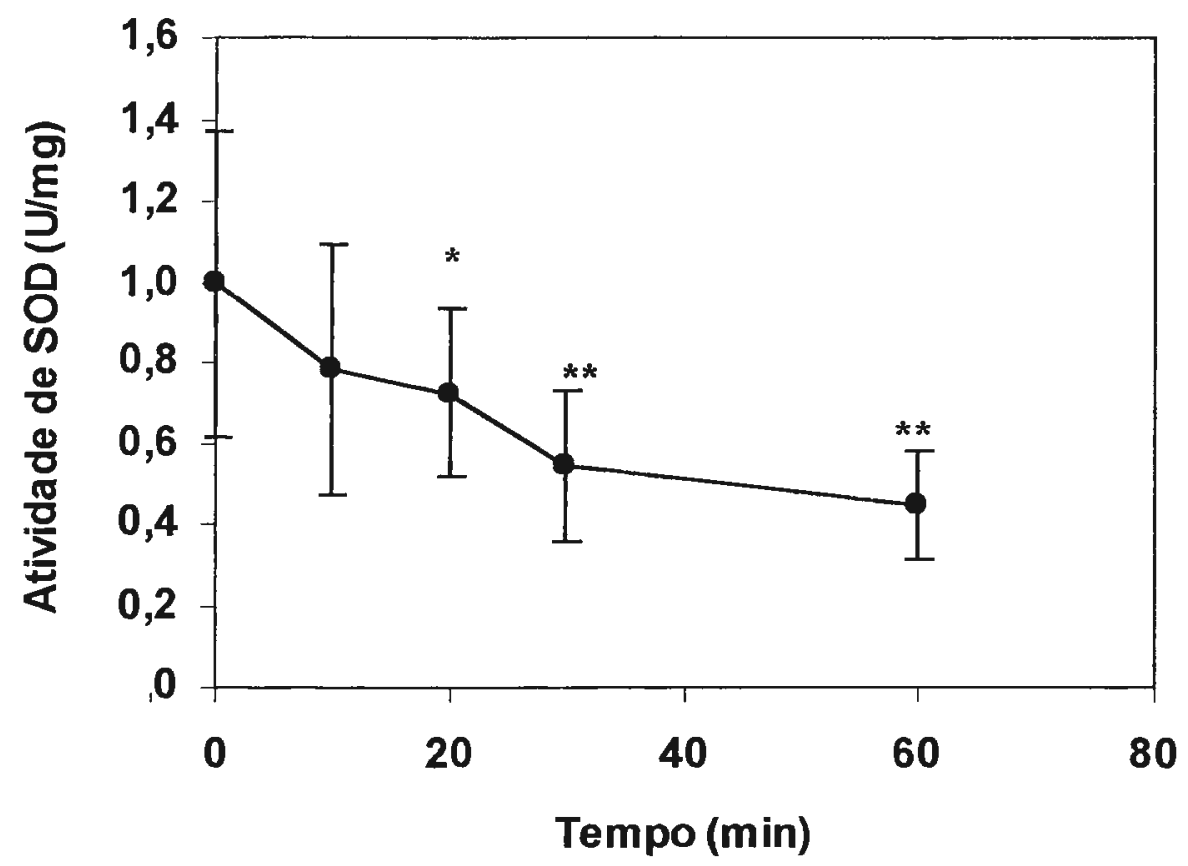

Fig. 21. Atividade total de SOD em glândulas submandibulares de ratos tratados com $\mathrm{CHX}$. Os animais foram tratados com $\mathrm{CHX}(50 \mathrm{mg} / \mathrm{kg})$ e as glândulas foram removidas em 10, 20, 30 e $60 \mathrm{~min}$ após o tratamento. 0 grupo controle foi tratado com $\mathrm{NaCl} 0,9 \%$. As diferenças entre o grupo tratado e o grupo controle são estatisticamente significantes * $(p<0,1), * *(p<0,05), n=3$. 


\section{Tabela 1}

Atividade total de SOD após tratamento com ISO e CHX in vivo.

\begin{tabular}{cc|c}
\hline Tempo (min) & \multicolumn{2}{c}{$\begin{array}{c}\text { Atividade total de SOD (U/mg de proteína) } \\
\text { variação (média/ controle) }\end{array}$} \\
\hline & \multicolumn{1}{c}{ ISO } & CHX \\
10 & $1,19 \pm 0,22$ & $0,78 \pm 0,31$ \\
20 & $1,55 \pm 0,19 *$ & $0,72 \pm 0,20 *$ \\
30 & $1,52 \pm 0,22 *$ & $0,54 \pm 0,18 * *$ \\
60 & $1,63 \pm 0,18 *$ & $0,45 \pm 0,13 * *$ \\
\hline
\end{tabular}

Os animais tratados com ISO ou CHX tiveram suas glândulas submandibulares removidas após 10, 20, 30 e $60 \mathrm{~min}$. 0 tecido foi homogeneizado e a atividade total de SOD foi medida. As diferenças entre o grupo tratado e o grupo controle são estatisticamente significantes $*(p<0,1), * *(p<0,05), n=3$. 


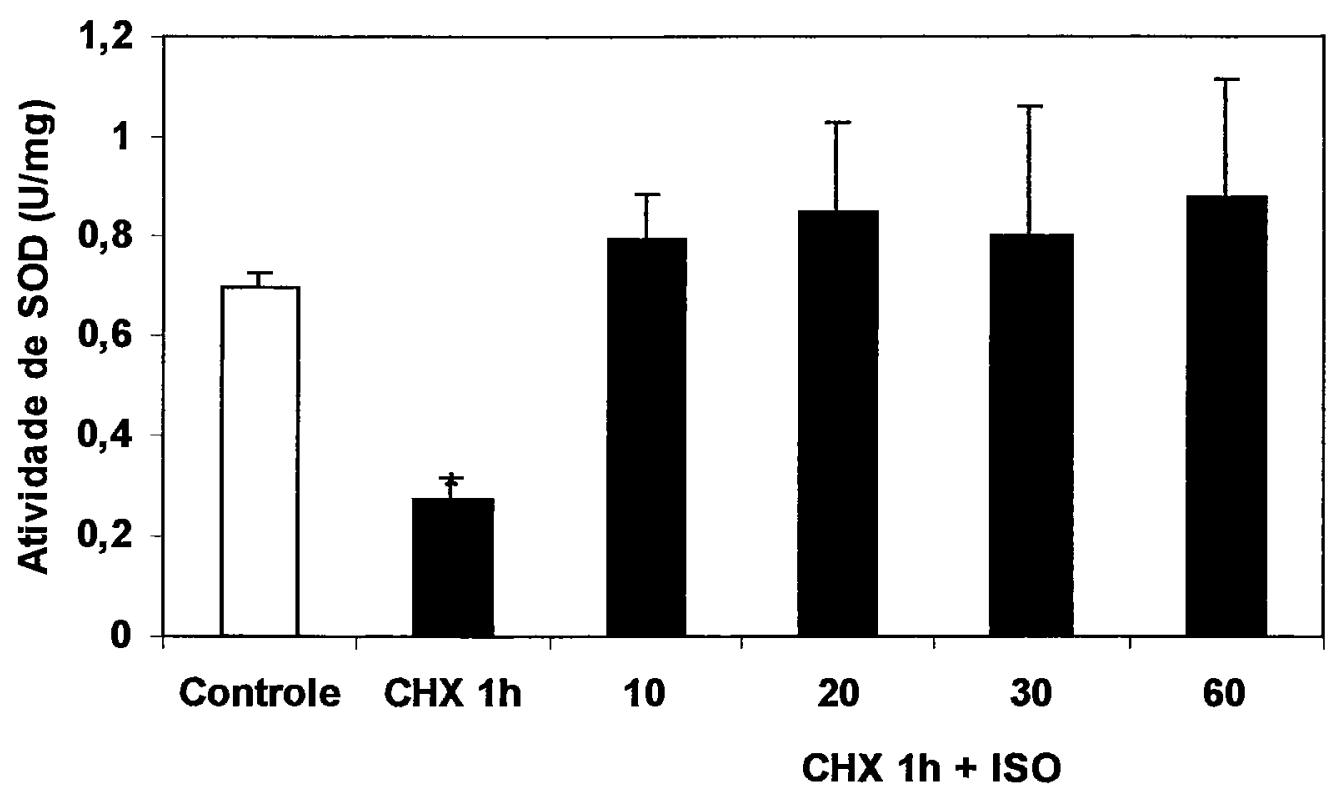

Fig. 22. Atividade Total de SOD em glândulas submandibulares de ratos tratados com CHX e ISO. Os animais foram tratados com CHX ( $50 \mathrm{mg} / \mathrm{kg}$ ) por $1 \mathrm{~h}$ e em seguida injetados com ISO (50 mg/kg). As glândulas foram removidas em 10, 20, 30 e 60 min após o tratamento com ISO. O grupo controle foi tratado com $\mathrm{NaCl} 0,9 \%$. * As diferenças entre o grupo tratado e o grupo controle são estatisticamente significantes $(p<0,05)$, $\mathrm{n}=3$. 
Tabela 2

Atividade total de SOD após o tratamento in vivo com $\mathrm{CHX}$ por $1 \mathrm{~h}$ seguido de ISO.

\begin{tabular}{cc}
\hline Tratamento & $\begin{array}{c}\text { Atividade total de SOD (U/mg de proteína) } \\
\text { variação (média/controle) }\end{array}$ \\
\hline CHX 1h & $0,38 \pm 0,048^{*}$ \\
CHX 1h + ISO 10 & $1,14 \pm 0,066$ \\
CHX 1h + ISO 20 & $1,21 \pm 0,11$ \\
CHX 1h + ISO 30 & $1,14 \pm 0,16$ \\
CHX 1h + ISO 60 & $1,25 \pm 0,12$ \\
\hline
\end{tabular}

Os animais foram tratados com $\mathrm{CHX}(50 \mathrm{mg} / \mathrm{kg})$ por $1 \mathrm{~h}$ e em seguida injetados com ISO (50 mg/kg). As glândulas foram removidas em 10, 20, 30 e 60 min após o tratamento com ISO. O tecido foi homogeneizado e a atividade total de SOD foi medida. $O$ grupo controle foi tratado com $\mathrm{NaCl} 0,9 \%$. As diferenças entre o grupo tratado e o grupo controle são estatisticamente significantes * $(\mathrm{p}<0,05), \mathrm{n}=3$. 


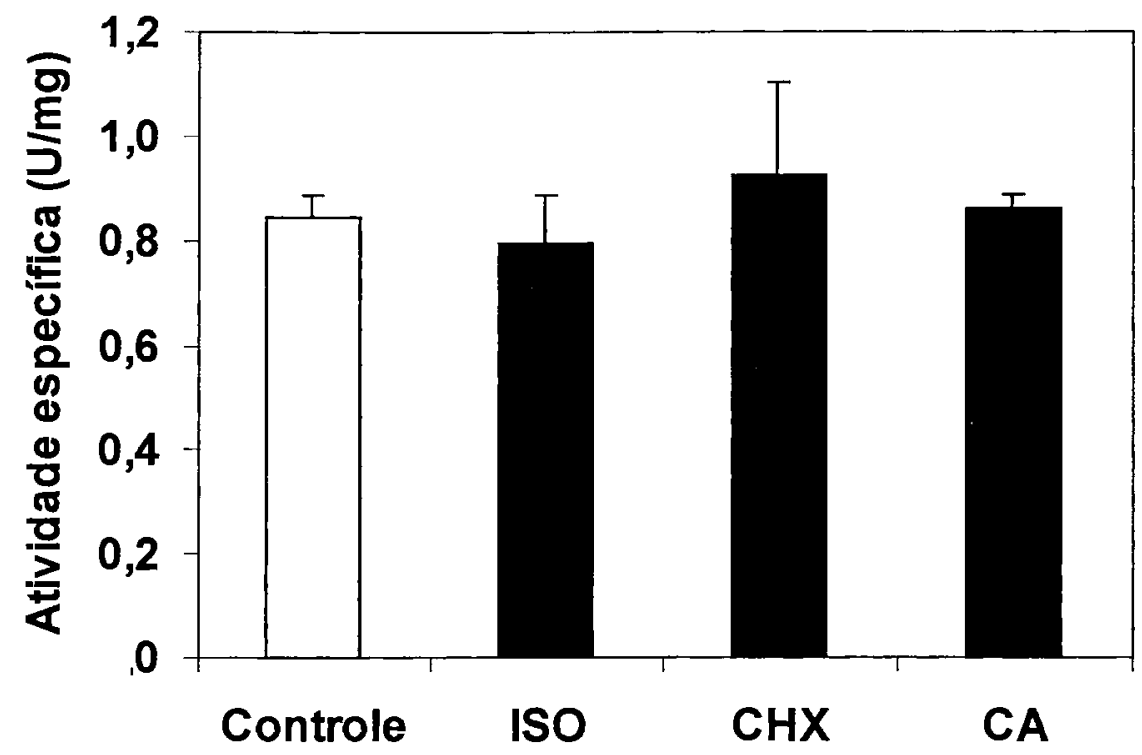

Fig. 23. Atividade total de SOD em extrato bruto de glândulas submandibulares, exposto ao ISO, CHX e ao CA. Homogenados $(\mathrm{n}=3)$ à concentração de $1 \mathrm{mg} / \mathrm{mL}$ foram incubados com CA $(10 \mu \mathrm{M})$, ISO $(10 \mu \mathrm{M})$ e $\mathrm{CHX}(10 \mathrm{mg} / \mathrm{mL})$ por $20 \mathrm{~min}$. O grupo controle foi incubado com $\mathrm{NaCl} 0,9 \%$. 


\subsection{Detecção de isoformas de SOD por "Western Blot".}

Assim como a variação na atividade da enzima SOD foi observada após o tratamento com ISO e $\mathrm{CHX}$, verificou-se também a variação nos níveis protéicos de CuZnSOD e MnSOD por imunodetecção em "Western Blot". Os anticorpos policlonais anti-CuZnSOD e anti-MnSOD reagiram no homogenado com as isoformas CuZnSOD e MnSOD.

Os resultados do "Western Blot" e da densitometria mostram que ocorreu um pequeno aumento de 1,2 e 1,3 vezes nos níveis protéicos de CuZnSOD em glândula de animais tratados com ISO aos 30 e 60 min após o tratamento, respectivamente, enquanto não houve alteração no nível de CuZnSOD quando os animais foram tratados com CHX (Fig. 24).

A análise densitométrica da figura 25 revela que a isoforma MnSOD aumenta em níveis protéicos de 1,8 a 5 vezes mais em glândulas de animais tratados com ISO do que glândulas de animais não tratados. Já no tratamento com $\mathrm{CHX}$ não houve variação no nível de MnSOD em glândulas de animais tratados comparando-se ao grupo controle. 
A

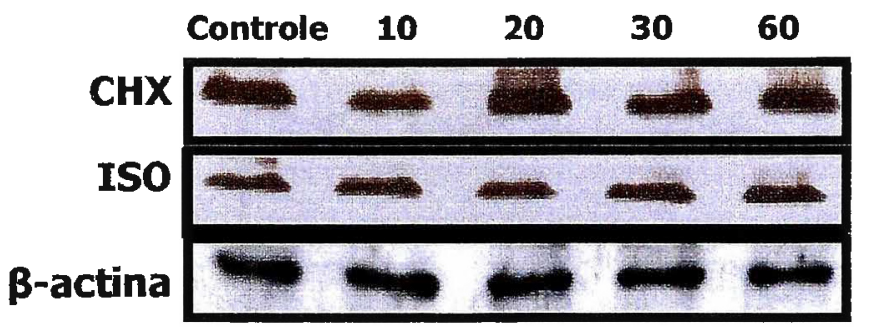

B

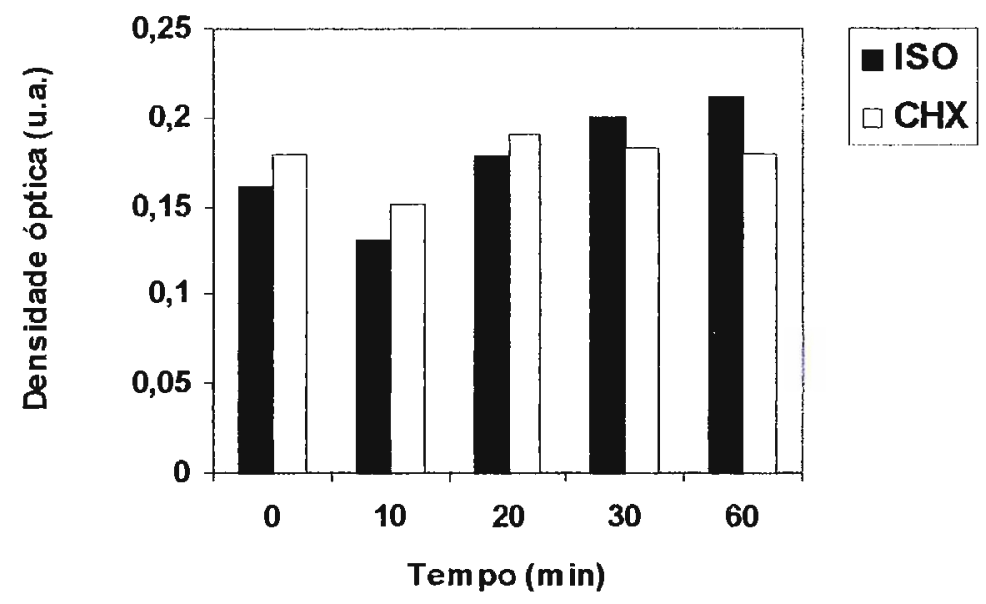

Fig. 24. A. Imunodetecção com anti-CuZnSOD. Os animais foram tratados com ISO $(50 \mathrm{mg} / \mathrm{Kg})$ e $\mathrm{CHX}(50 \mathrm{mg} / \mathrm{Kg})$ e as glândulas submandibulares foram removidas após $10,20,30$ e 60 min da injeção. $O$ grupo controle foi tratado com $\mathrm{NaCl} 0,9 \%$. Os homogenados $(50 \mu \mathrm{g})$, obtidos como descritos no item 3.3.3., foram separados em gel de poliacrilamida $12 \%$ e transferidos para membrana de PVDF para a imunodeteç̧ão com anti-CUZn SOD. A foto mostra a detecção da isoforma em filme radiográfico. B. Densitometria do filme radiográfico da isoforma CuZnSOD após tratamento com ISO e CHX. 
$\mathbf{A}$

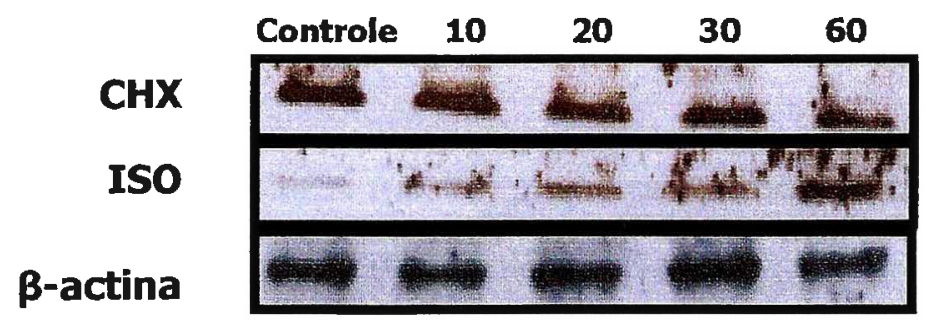

B

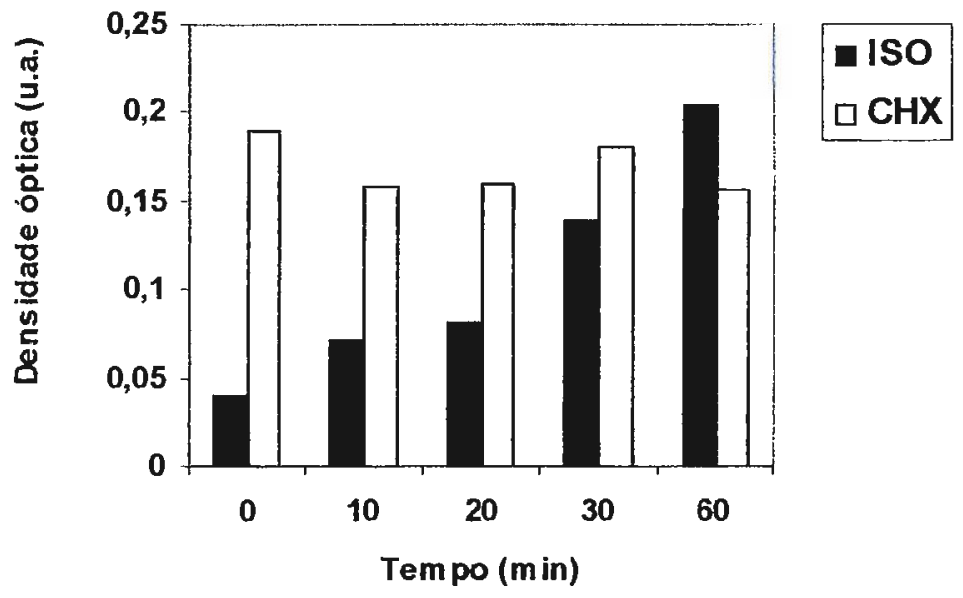

Fig. 25. A. Imunodetecção com anti-MnSOD. Os animais foram tratados com ISO $(50 \mathrm{mg} / \mathrm{Kg})$ e $\mathrm{CHX}(50 \mathrm{mg} / \mathrm{Kg})$ e as glândulas submandibulares foram removidas após 10, 20, 30 e 60 min da injeção. 0 grupo controle foi tratado com $\mathrm{NaCl} 0,9 \%$. Os homogenados $(50 \mu \mathrm{g})$, obtidos como descritos no item 3.3.3., foram separados em gel de poliacrilamida $12 \%$ e transferidos para membrana de PVDF para a imunodetecção com antiMnSOD. A foto mostra a deteç̧ão da isoforma em filme radiográfico. B. Densitometria do filme radiográfico da isoforma MnSOD após tratamento com ISO e CHX. 


\subsection{Padrão de atividade total de SOD em células dispersas.}

Os experimentos anteriores mostraram aumento na atividade de SOD e dos níveis protéicos após o tratamento in vivo com ISO, mas o mesmo não ocorreu quando o tratamento foi feito com CA. A indução da atividade de SOD e seu mecanismo de controle por meio de receptores adrenérgicos e colinérgicos ainda é pouco conhecida.

Para verificarmos a ação de agentes adrenérgicos e colinérgicos foram feitas análises da atividade de SOD em células dispersas purificadas de glândulas salivares de rato incubadas com CA, CHX, ISO e PROP.

A incubação com CA revelou um aumento na atividade de SOD em 20 min, 13\% e $30 \mathrm{~min}, 26 \%$ (Fig. 26). Quando as células foram incubadas com CHX houve um aumento na atividade de SOD em $30 \mathrm{~min}$ (49\%) (Fig.27).

No entanto a atividade de SOD medida no homogenado de células dispersas

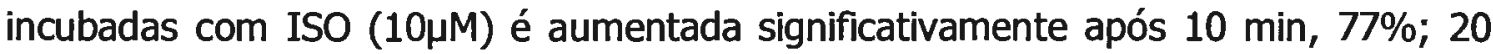
$\min , 48 \%$ e $30 \mathrm{~min}, 90 \%$ (Fig. 28). Com isso o ISO, um conhecido ativador de receptores $\beta$-adrenérgicos, provocou um aumento significativo na atividade de SOD.

Para verificar se a via de ativação de atividade de SOD, por estimulação com ISO, ocorre de forma dependente da ativação à receptores $\beta$-adrenérgicos, as células foram pré-incubadas com PROP, um conhecido bloqueador $\beta$-adrenérgico antes da incubação com ISO, a fim de que os receptores para ISO fossem bloqueados. 
A atividade de SOD não teve alteração significativa quando foi realizado o prétratamento com PROP seguido de ISO, mas foi aumentada quando foi feito somente o tratamento com ISO (63\%) (Fig. 29). 


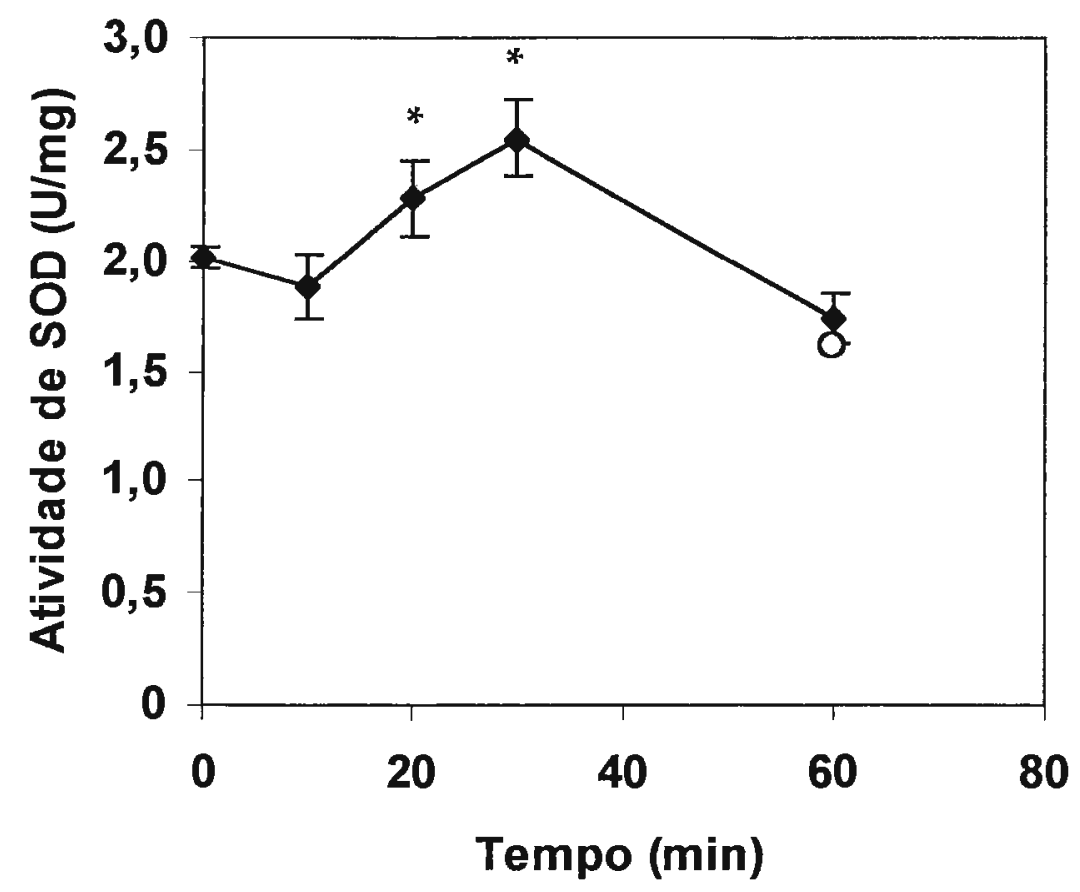

Fig. 26. Atividade total de SOD medida em células dispersas de glândulas submandibulares de ratos expostas ao CA. A cultura de células foi tratada com CA $(10 \mu \mathrm{M})$ por 10,20 , 30 e $60 \mathrm{~min}$. O grupo controle foi tratado com $\mathrm{NaCl} 0,9 \%$. 0 controle de tempo de incubação (-O-) foi tratado com $\mathrm{NaCl}$ 0,9\%. foi mantido por 60 min em cultura. * As diferenças entre o grupo tratado e o grupo controle são estatisticamente significantes $(p<0,05), n=3$. 


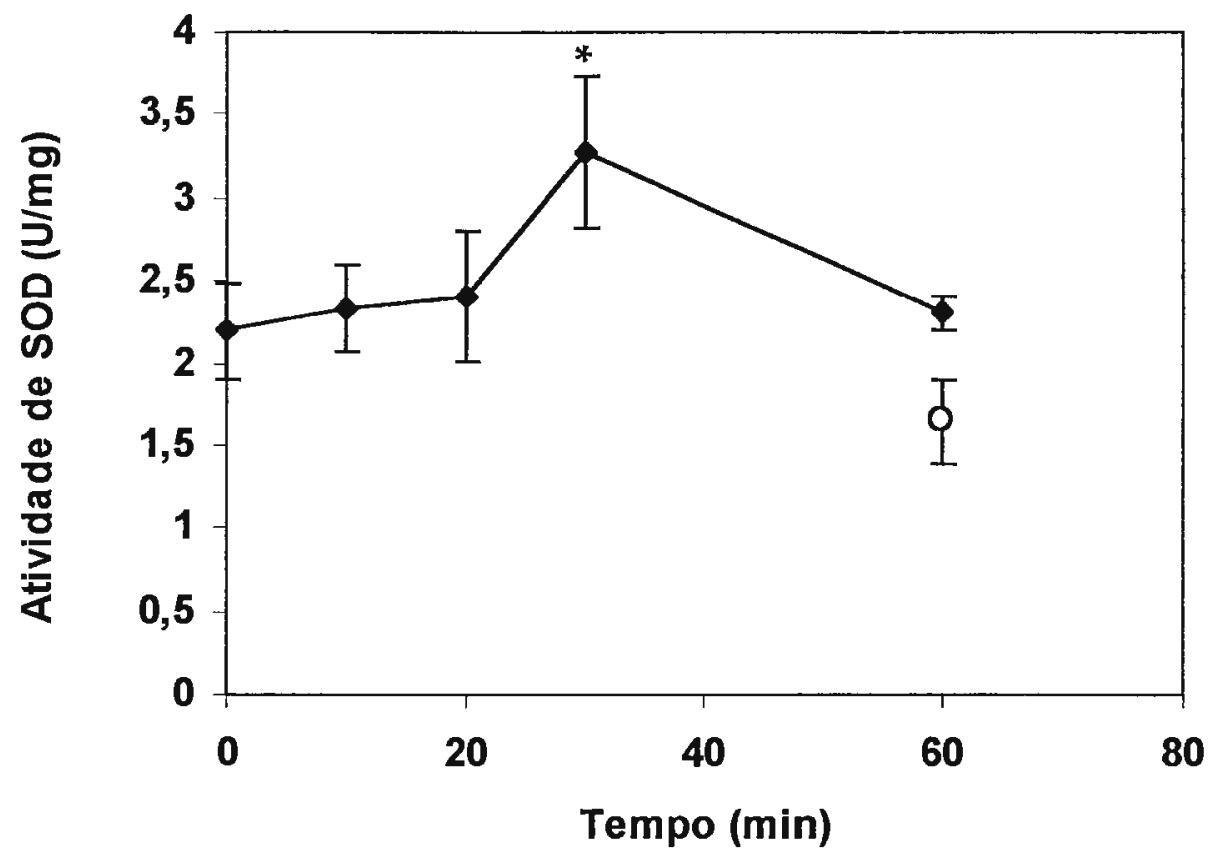

Fig. 27. Atividade total de SOD medida em células dispersas de glândulas submandibulares de ratos expostas à $\mathbf{C H X}$. A cultura de células foi tratada com $\mathrm{CHX}(10 \mathrm{mg} / \mathrm{mL})$ por 10, 20, 30 e 60 min. O grupo controle foi tratado com $\mathrm{NaCl}$ 0,9\%. $\mathrm{O}$ controle de tempo de incubação (-O) foi tratado com $\mathrm{NaCl}$ 0,9\%. foi mantido por 60 min em cultura. * As diferenças entre o grupo tratado e o grupo controle são estatisticamente significantes $(p<0,05), n=3$. 


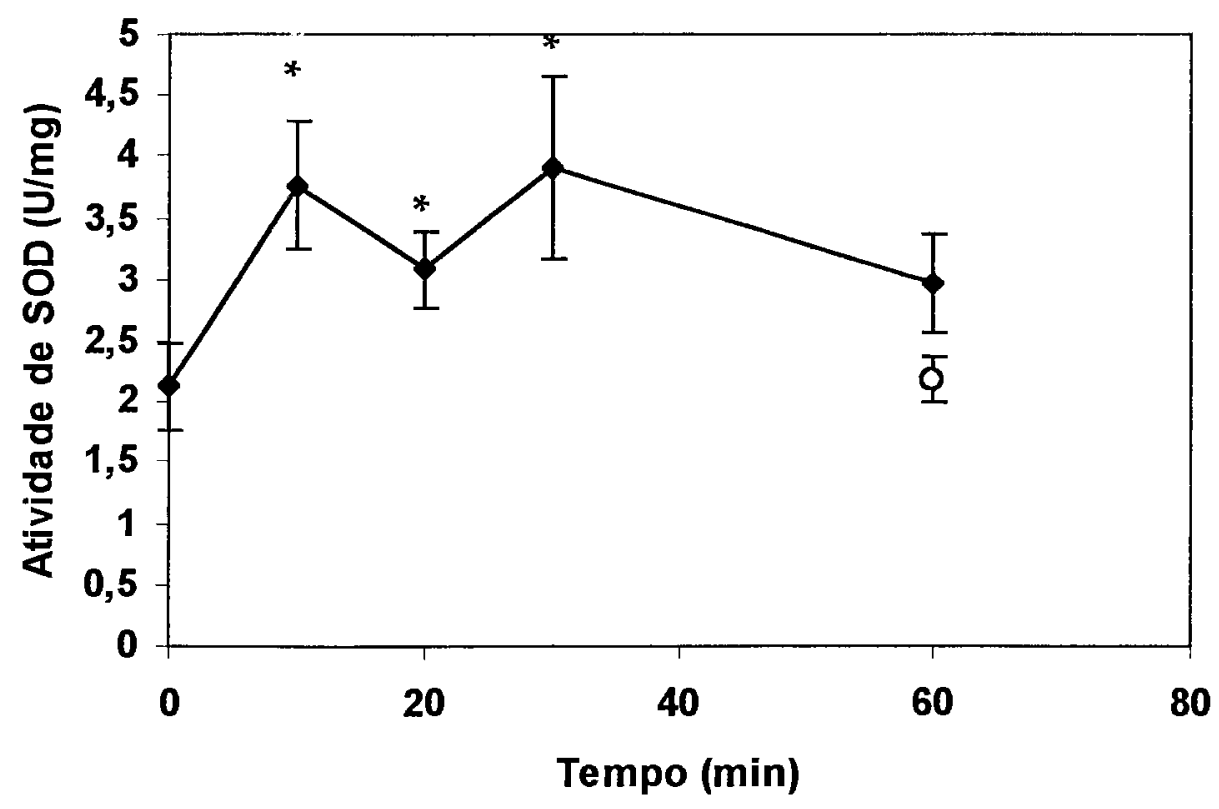

Fig. 28. Atividade total de SOD medida em células dispersas de glândulas submandibulares de ratos expostas ao ISO. A cultura de células foi tratada com ISO $(10 \mu \mathrm{M})$ por 10 , 20,30 e 60 min. O grupo controle foi tratado com $\mathrm{NaCl}$ 0,9\%. O controle de tempo de incubação (-O-) foi tratado com $\mathrm{NaCl} 0,9 \%$. foi mantido por $60 \mathrm{~min}$ em cultura. * As diferenças entre o grupo tratado e o grupo controle são estatisticamente significantes $(p<0,05), n=3$. 


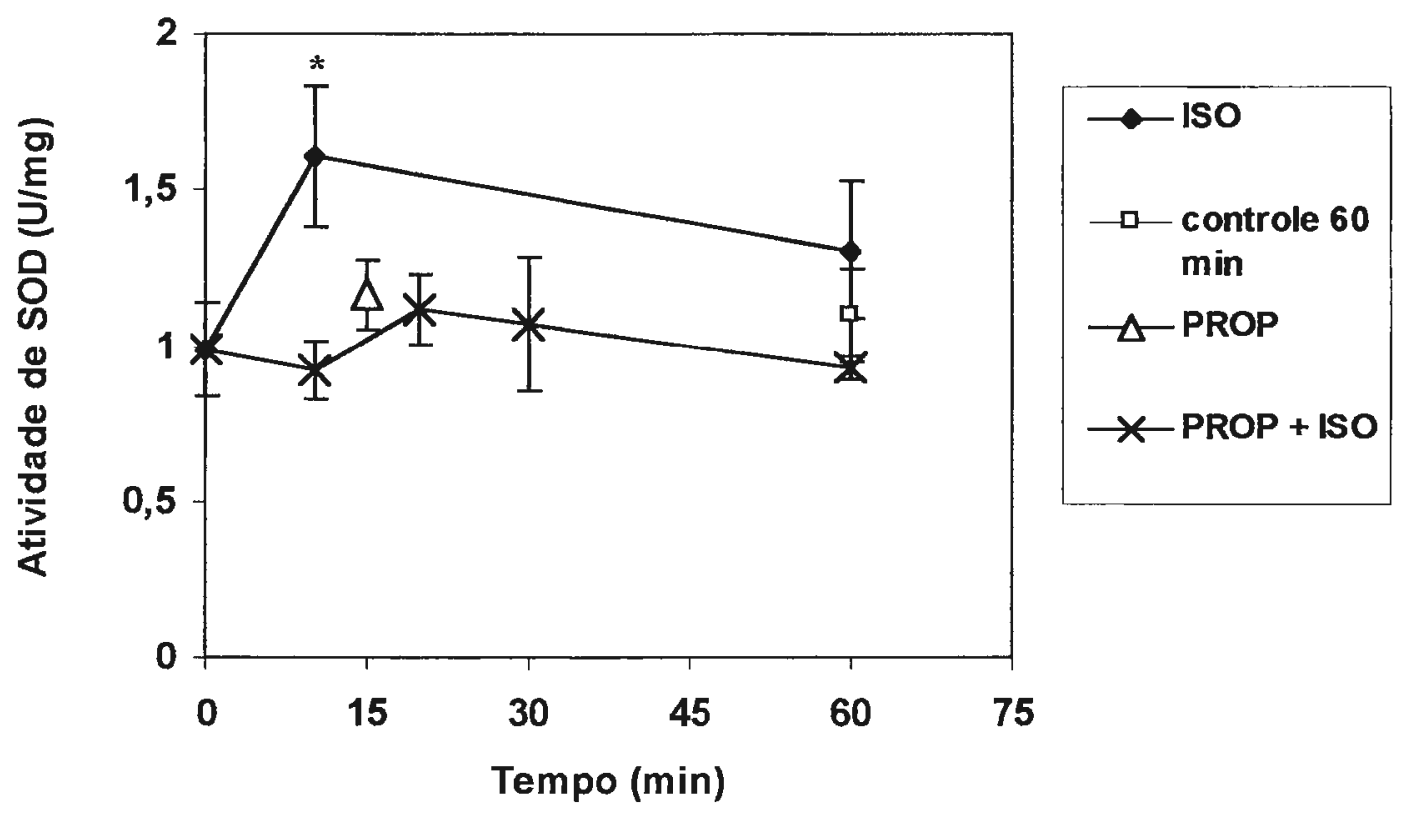

Fig. 29. Atividade total de SOD medida em células dispersas de glândulas submandibulares de ratos expostas ao ISO e PROP. A cultura de células foi tratada com PROP (20 $\mu \mathrm{M})$ por5 min e em seguida com ISO $(10 \mu \mathrm{M})$ por $10,20,30$ e 60 min. Os controles do ensaio foram tratados com $\mathrm{NaCl} 0,9 \%$ ou PROP por 20 min. * As diferenças entre o grupo tratado e o grupo controle são estatisticamente significantes $(p<0,05), n=3$. 


\section{Discussão}

A saliva é composta pelo conjunto de proteínas e de eletrólitos secretados pelas células das glândulas salivares (Mandel, 1987). As secreções protéica e fluida das glândulas salivares são reguladas fisiologicamente por meio da inervação simpática e parassimpática. O ISO é um agonista $\beta$-adrenérgico capaz de ativar a exocitose em glândulas salivares (Quissell et al., 1983; Takuma, 1990). O mecanismo de ativação da secreção salivar por ISO já é conhecido (Quissell et al., 1983). Inicialmente ele age em receptores de membrana ( $\beta$-adrenérgico) levando a um aumento da concentração de cAMP intracelular, que por sua vez ativa a PKA, que promove a fosforilação de uma proteína localizada em vesículas (p26), permitindo assim a fusão da vesícula com a membrana plasmática (exocitose). Além deste efeito direto na secreção de vesículas, o ISO é capaz de ativar molecularmente fatores de transcrição como o complexo AP-1 que é responsável pela ativação de genes tais como da $\alpha$-amilase e proteínas ricas em prolina (Zhou et al., 1997; Lazowski et al., 1992). Já o CA é um agonista colinérgico envolvido na ativação de canais responsáveis pela secreção de eletrólitos (Martinez, 1990; Martinez, 1987).

O processo secretónio é dependente de energia, que é obtida no metabolismo celular. Estudos mostram que a estimulação da secreção salivar leva a um aumento de consumo simultâneo de glicose e de oxigênio (Nicolau \& Sassaki, 1976). Esse aumento de consumo energético, se comparadas as glândulas, é maior nas glândulas submandibulares do que na parótida e sublingual, sendo que a via glicolítica é a principal fonte de obtenção de energia nas células de glândulas submandibulares 
(Nicolau \& Sassaki, 1976). Sabe-se também que o tratamento de ratos com uma dose de ISO, que é um agonista $\beta$-adrenérgico, causa o aumento do consumo de oxigênio e de glicose em glândulas salivares (Nicolau \& Sassaki, 1983). Em tratamentos realizados com CA, também se observa um aumento significativo no consumo de oxigênio nas glândulas submandibulares de ratos. Já em glândulas parótidas de ratos tratados com CA o consumo de oxigênio modifica-se com a idade do animal. Ocorre um aumento do consumo de oxigênio nas glândulas após o tratamento de ratos de duas semanas de idade, sendo que o mesmo não é observado em glândulas de animais recém-nascidos tratados também com CA. Desta forma estes estudos revelam diferenças no desenvolvimento e no metabolismo das glândulas submandibular e parótida (Stojic, 1998).

Em cultura primária de células de glândulas submandibulares há a necessidade de um ambiente de alta concentração de oxigênio para a sobrevivência da cultura em boas condições. As células em cultura sobrevivem em 20, 35 ou 50\% de oxigênio, sendo que em condições de $35 \%$ de $\mathrm{O}_{2}$ as células permanecem com todas as características acinares e em especial, respondem a agonistas. Outras culturas de células, no entanto sofrem indução de apoptose induzida por estresse oxidativo sob condições como estas. (Quissell et al., 1994; Kubo et al., 1996). Naturalmente nestas condições de sobrevivência, pode-se sugerir que nestas glândulas o sistema antioxidante intracelular deve exercer um papel essencial. As enzimas antioxidantes, tais como SOD e catalase devem ter sua regulação molecular extremamente sensivel. 
Uma das principais fontes geradoras de ERO é a cadeia de transporte de elétrons na mitocôndria. Algumas ERO, como $\mathrm{H}_{2} \mathrm{O}_{2}$ são geradas pela mitocôndria e correspondem a $2 \%$ do total de oxigênio captado. Neste processo $\circ \mathrm{O}_{2}$ recebe um elétron e se reduz a $\mathrm{O}_{2}{ }^{\circ-}$, que por sua vez é o substrato para a enzima MnSOD localizada na mitocôndria. Esta enzima causa a dismutação do $\mathrm{O}_{2} \cdot-$ formando $\mathrm{H}_{2} \mathrm{O}_{2}$ e $\mathrm{O}_{2}$ (Boveris \& Chance, 1973; Turrens \& Boveris, 1980).

$\mathrm{O}_{2} \mathrm{O}_{2}$ gerado é capaz de passar por entre as membranas e reagir com o $\mathrm{Fe}^{2+}$ ou $\mathrm{Cu}^{2+}$ para formar o $\mathrm{HO}^{*}$ por meio da reação de Fenton, ou pode ainda reagir com $\mathrm{O}_{2}{ }^{--}$formando também $\mathrm{HO}^{\bullet}$ por meio da reação de Haber-Weiss. Essas ERO, $\mathrm{O}_{2}{ }^{\bullet-}$, $\mathrm{H}_{2} \mathrm{O}_{2}$ e $\mathrm{HO}^{\circ}$, têm sido implicadas na mutagênese e morte celular (Wiseman \& Haliwell, 1996; Rollet, 1998), assim como na transdução de sinais e na regulação da expressão de diversos genes como c-jun, JNK e p38 entre outros (Allen \& Tresini, 2000).

Para impedir que ocorra um desbalanço no potencial redox da célula, que pode induzir ao estresse oxidativo e causar sérias conseqüências irreversíveis e deletérias, os sistemas antioxidantes celulares enzimáticos e não enzimáticos agem para impedir que ocorra o dano oxidativo. Fazem parte deste sistema as enzimas SOD, CAT, GPx e os compostos GSH, vitamina C, vitamina E e vitamina A entre outros (Haliwell \& Gutteridge, 1999; Gaté et al., 1999). Então, as linhas centrais de defesa celular contra o desbalanço redox intracelular são ativadas imediatamente quando as ERO são geradas durante o metabolismo aeróbico.

O aumento de consumo de oxigênio molecular pelas glândulas salivares após a injeção com ISO e CA relatados na literatura sugere maior chance de produção de 
ERO e portanto maior possibilidade de oxidação de moléculas como lipídios e proteínas. As catecolaminas em geral, o que inclui o ISO, provocam a produção de ERO em coração. Além disto, sabe-se que tratamentos crônicos com ISO causam hipertrofia em coração e rim e provocam aumento na peroxidação lipídica (Bors, 1978; Rathore et al., 1998).

Sabe-se que estimulantes de membrana $\beta$-adrenérgicos, como o ISO estimulam ácinos de glândulas submandibulares, que constituem $60 \%$ da glândula e são responsáveis pela síntese da maioria das proteínas salivares. O estudo da ação do ISO em células dispersas é muito valioso, pois o procedimento de dispersão celular mantém as características funcionais de secreção da célula em cultura. Ao mesmo tempo, o procedimento de dispersão gera uma condição de estresse que pode ter conseqüências à moléculas como lipídios e proteínas (Baum et al., 1990; Quissell et al., 1979).

Neste trabalho abordamos duas metodologias diferentes para estudar os efeitos de ISO, CHX e CHX + ISO sobre as glândulas submandibulares de rato. No primeiro caso estudamos os efeitos de tratamentos agudos in vivo destas drogas. Na segunda abordagem estudamos os efeitos das mesmas drogas em cultura de células dispersas. Verificou-se que ISO, $\mathrm{CHX}$ e $\mathrm{CHX}+$ ISO induziram um aumento significativo na produção de MDA/mg de proteína. No entanto, efeitos diferentes foram encontrados após a incubação de células dispersas com ISO, CHX e CHX + ISO. Somente as células incubadas com $\mathrm{CHX}$ apresentaram resultados semelhantes aos encontrados in vivo. Enquanto os dados sugerem que os tratamentos in vivo provoquem um aumento do nível de MDA, o nível de carbonilas protéicas, produzidas 
na oxidação de proteínas não foi alterado em nenhum dos tratamentos in vivo, mas os tratamentos com ISO, $\mathrm{CHX}$ e $\mathrm{CHX}$ seguido de ISO em células dispersas provocaram um aumento na oxidação protéica.

À medida que se observa a oxidação de moléculas em diferentes condições, o estudo da modulação de agentes antioxidantes estimulados pelos mesmos tratamentos faz-se necessário para esclarecer sobre o estado oxidativo da célula.

A GSH presente nas células é outra molécula extremamente importante relacionado ao controle intracelular das ERO. Em células cerebrais o conteúdo de GSH está relacionado com o estresse oxidativo associado a diversas patologias neurológicas (Dringen, 2000). A modulação do conteúdo intracelular de GSH também modula a ação das ERO produzidas em respostas inflamatórias agudas e crônicas por meio da regulação do estado redox da célula (Rahman \& MacNee, 2000).

Em nossos experimentos em ratos tratados com ISO, observou-se um aumento na produção de MDA por mg de proteína. Estes resultados sugerem uma condição pró-oxidante, mas que deva ser compensada com um concomitante aumento do poder redutor (GSH/2GSSG) nas mesmas condições de tratamento. Estes resultados, associados às dosagens obtidas da atividade enzimática de SOD sob o mesmo tratamento reafirmam que exista uma proteção antioxidante após o tratamento com ISO. Um aumento semelhante foi verificado na incubação das células dispersas com ISO sugerindo que o aumento de atividade de SOD esteja relaçiona do com a porção secretora da glândula, uma vez que a cultura de células contém somente a porção acinar. 
Em relação a ratos tratados com $\mathrm{CHX}$, a redução no poder redutor revela um estado pró-oxidativo. Já em ratos tratados com $\mathrm{CHX}+\mathrm{ISO}$ ocorreu um aumento no poder redutor. Em células dispersas tanto a incubação com $\mathrm{CHX}$ como a incubação com $\mathrm{CHX}+\mathrm{ISO}$ não provocaram alterações no poder redutor. Estas variações, resultantes de estímulos variados, sugerem que além do estímulo, a diferença entre o modelo e o mecanismo de ativação celular interfira na resposta obtida.

Além do poder redutor, a atividade da enzima SOD foi um outro parâmetro antioxidante utilizado para avaliar o estresse oxidativo nas glândulas. A SOD é considerada como primeira linha de defesa antioxidante e também tem uma função protetora para outras enzimas. Um estudo mostrou que ela é capaz de proteger a inativação da proteína fosfatase $2 \mathrm{~B}$, conhecida como calcineurina, responsável pela regulação de diversos mecanismos dependentes de fosforilação e desfosforilação na célula. O estado redox da célula e, mais especificamente, o estado redox do Fe é capaz de regular a atividade da calcineurina, uma vez que a mesma contém Fe-Zn em seu centro ativo. Como a SOD tem um papel na regulação do estado redox da célula, esta enzima também tem um papel fisiológico na modulação deste processo de mecanismos dependentes de fosforilação reversível de proteínas (Wang et al., 1996).

Os agentes colinérgicos são responsáveis pela secreção salivar fluida (Melvin et al., 1987; Nakahari et al., 2000). Em glândulas salivares eles ativạm a via de transdução de sinal dependente de PKC (proteina quinase C) (Soltoff \& Toker, 1995; Quissell et al., 1992). Embora existam relatos sobre a indução de SOD dependente da via de PKC por estimulação com forbol (Armstead, 1999), outros autores relatam 
a existência de uma via dependente e de outra independente de PKC para a indução da MnSOD especificamente (Fuji \& Taniguchi, 1994). Nossos resultados mostram que enquanto o tratamento realizado in vivo com CA, um agente colinérgico, não interferiu na atividade de SOD, o tratamento in vitro com CA mostrou um ligeiro aumento na atividade da enzima.

Estudos mostram que a expressão de genes em resposta ao estresse oxidativo é ativada de maneira tecido-específica e que diversos tratamentos podem induzir ao aumento da expressão de SOD. $\mathrm{O}_{2} \mathrm{O}_{2}$, por exemplo, em hepatócitos é capaz de causar o aumento de MnSOD, mas não de CuZnSOD. (Rohrdanz \& Kahl, 1998).

Seguindo a linha de especificidade de tecido e sabendo que o ISO estimula as funções secretórias das glândulas salivares, nossos resultados sugerem que a enzima SOD em glândulas submandibulares possa ser ativada por vias semelhantes às secretoras, atuando como protetora das possíveis EROs produzidas durante o metabolismo celular.

Da mesma forma, em células dispersas verificou-se padrão de ativação de SOD por ISO semelhante ao encontrado in vivo de SOD sugerindo assim que o mecanismo antioxidante possa ser ativado conjuntamente com o processo de exocitose, favorecendo a proteção contra o ataque das ERO produzidas durante o metabolismo celular. Os resultados obtidos com ambos os agentes CA e ISO sugerem que a regulação da atividade de SOD ocorra por via $\beta$-adrenérgica.

As enzimas antioxidantes têm sido alvo de muitos estudos e algumas substâncias são capazes de induzí-las em vários níveis. A anisomicina e a $\mathrm{CHX}$, ambos inibidores da síntese protéica, podem induzir o mRNA codificador para a 
MnSOD (Fuji et al., 1994). Embora se tenha observado um acúmulo de mRNA para a MnSOD causado pela $\mathrm{CHX}$, a síntese protéica foi bloqueada, sugerindo uma regulação na etapa de transcrição do gene.

Em nosso estudo verificamos o efeito da $\mathrm{CHX}$ na atividade de SOD. O tratamento de animais in vivo com $\mathrm{CHX}$ mostrou que a atividade total de SOD nas glândulas submandibulares diminui de forma dependente do tempo de atuação da droga in vivo. A mesma inibição não foi observada in vitro, onde a atividade de SOD apresentou um aumento após 30 min de incubação com $\mathrm{CHX}$. Essa diferença de resposta obtida em ensaios in vivo e in vitro após o tratamento com $\mathrm{CHX}$ demonstra que a regulação da SOD por $\mathrm{CHX}$ envolve mecanismos ainda desconhecidos. Neste mesmo contexto, verificamos que a inibição por $\mathrm{CHX}$ foi anulada por um tratamento posterior com ISO. Os animais receberam uma injeção prévia com CHX e após $1 \mathrm{~h}$ foi injetado ISO e verificado um aumento na atividade total da SOD. Isto sugere que exista uma regulação dependente da via iniciada pelo ISO, mesmo quando a atividade de SOD foi suprimida previamente por $\mathrm{CHX}$. Outra hipótese é que as vias de inibição por $\mathrm{CHX}$ e estimulação por ISO sejam distintas, sendo que a via $\beta$ adrenérgica seja predominante.

Tem sido relatado que a atividade de SOD aumenta por ativação de radiações UVB e citocinas. O estresse oxidativo também é capaz de ativar diferencialmente as isoformas CuZnSOD e MnSOD, sendo que aparentemente a expressão das duas isoformas ocorrerem por mecanismos distintos (Isoherrane et al., 1997). Também há relatos de regulação de MnSOD por mecanismo pós-transcricional por intermédio de 
uma proteína sensível ao potencial redox, que provoca o aumento da tradução do mRNA para MnSOD (Chung et al., 1998).

Nossos resultados de imunodetecção das duas isoformas também revelam uma diferença entre os níveis de CuZnSOD e MnSOD dependendo do tratamento realizado, mostrando que o ISO é capaz de interferir nos níveis protéicos de SOD. Estas alterações após o tratamento com ISO estão de acordo com relatos da literatura que mostram que a MnSOD é a principal isoforma regulada em diferentes níveis (Fujii et al., 1994; Hachiya et al., 1997).

Nossos resultados também indicam que a regulação da atividade de SOD deve ser complexa. Para verificarmos a existência da regulação da atividade de SOD por meio de receptores $\beta$-adrenérgicos, utilizamos propanolol, um bloqueador $\beta$ adrenérgico não seletivo. Este bloqueador quando utilizado in vivo não altera o fluxo salivar, mas reduz o conteúdo protéico da saliva, demonstrando agir inibindo a via de secreção protéica (Nederfors \& Dahlöf, 1992).

Neste trabalho, enquanto o grupo tratado com ISO mostrou um aumento na atividade total de SOD, o grupo pré-tratado com propanolol seguido do tratamento com ISO não apresentou aumento de atividade enzimática. Esta observação sugere que os receptores $\beta$-adrenérgicos estão envolvidos na ativação da enzima SOD. Assim, o aumento da atividade de SOD produzido por ISO depende das vias de transdução de sinal ativadas por receptores $\beta$-adrenérgicos. Foi descartada a hipótese do ISO ativar diretamente a enzima SOD, pois resultados de incubação de ISO com homogenado e com o padrão de SOD comercial não mostraram qualquer ativação da enzima. 
As respostas encontradas in vivo e in vitro sugerem a indução da atividade de SOD sob controle $\beta$-adrenérgico. In vivo esta indução foi acompanhada de uma condição pró-oxidante instalada após o tratamento com ISO, observada por meio do aumento da produção de MDA por mg de proteínas. Nestas condições, além da proteção dada pela enzima SOD, existe o aumento do poder redutor (conteúdo de GSH), sugerindo que estes dois agentes atuem protegendo as glândulas in vivo nas situações estudadas. 


\section{Considerações Finais}

As avaliações feitas neste trabalho evidenciam que:

$>\mathrm{O}$ nível de MDA por $\mathrm{mg}$ de proteína aumentou em tratamentos in vivo com ISO, $\mathrm{CHX}$ e $\mathrm{CHX}+\mathrm{ISO}$. Em cultura de células o nível de MDA por mg de proteina aumentou no tratamento com $\mathrm{CHX}$.

$>\mathrm{O}$ nível de carbonilas formadas por $\mathrm{mg}$ de proteína foi reduzido in vivo com tratamentos com ISO e $\mathrm{CHX}+\mathrm{ISO}$. Em cultura de células o nível de carbonilas formadas por $\mathrm{mg}$ de proteína foi aumentado com tratamentos com ISO, CHX e CHX+ISO.

$>$ Os níveis de GSH aumentaram in vivo sob tratamento com ISO e diminuiram sob tratamento com $\mathrm{CHX}$.

A atividade de SOD sofreu um aumento em células em cultura estimuladas com CA, CHX e ISO. O tratamento in vivo com ISO levou ao aumento da atividade de SOD e uma diminuição da atividade de SOD em ratos tratados com $\mathrm{CHX}$, que pode ser recuperada pelo tratamento com ISO.

A MnSOD é a isoforma induzida pelo tratamento com ISO

$>\mathrm{O}$ tratamento prévio com PROP das células em cultura impediu o aumento da atividade de SOD induzida por ISO, sugerindo uma regulação de SOD por via $\beta$-adrenérgica. 


\section{Referências Bibliográficas}

Abraham, C.M., Al-Achei, I. \& Haghighat, N. (1998). Evaluation of the levels of oral Candida in patients with Sjögren's syndrome. Oral Surg. Oral Med. Oral Pathol., 86: 65-68.

Allen, R.G. \& Tresini, M. (2000). Oxidative stress and gene regulation. Free Rad. Biol. Med., 28: 463-499.

Armstead, W.M. (1999). Superoxide generation links protein kinase C activation to impaired ATP-sensitive K+ channel function after brain injury. Stroke, 30: 153159.

Au, D.K., Malbon, C.C. \& Butcher, F.R. (1977). Identification and characterization of $\beta 1$-adrenergic receptors in rat parotid membranes. Biochim. Biophys. Acta, 500: $361-371$

Barka, T. (1965). Induced cell proliferation: the effect of isoproterenol. Cell Tissue Res., 37: 667-670.

Batzri, S., Selinger, Z., Schramm, M \& Robinovitch, M.R. (1973). Potassium release mediated by epinephrine $\alpha$-receptor in rat parotid slices. J. Biol. Chem., 248: $361-368$. 
Baum, B.J., Colpo, F.T. \& Filburn, C.R. (1981). Characterization and relationship to exocrine secretion of rat parotid gland cyclic AMP-dependent protein kinase. Arch. Oral. Biol., 26: 333-337.

Baum, B.J., Ambudkar, I.S., Helman, J., Horn, V.J., Melvin, J.E., Mertz, L.M. \& Turner, R.J. (1990). Dispersed salivary gland acinar cell preparations for use in studies of neuroreceptor-coupled secretory events. Methods Enzymol., 192: 26-37.

Bennick, A., Mc Laughlin, A.C., Grey, A.A. \& Madapallimattam, G. (1981). The location and nature of calcium-binding sites in salivary acidic prolin-rich proteins. J. Biol. Chem., 256: 4741-4766.

Bennick, A. (1982). Salivary proline-rich proteins. Mol. Cell. Biochem., 45: 83.

Bercier, J.G., Al-Hashimi, I., Haghighat, N., Rees, T.D. \& Oppenheim, F.G. (1999). Salivary histatins in patients with recurrent oral candidiasis. J. Oral. Pathol. Med., 28: 26-29.

Bors, W., Michael, C., Saran, M \& Lengefelder, E. (1978). The involvement of oxygen radicals during the autooxidation of adrenaline. Biochim. Biophys. Acta, 540: 162-172.

Boveris, A. \& Chance, B. (1973). The mitochondrial generation of hydrogen peroxide. General properties and effect of hyperbaric oxygen. Biochem. J., 134: 707-716. 
Bradford, M.A. (1976). A rapid and sensitive method for quantification of microgram quantities of protein utilizing the principle of protein-dye binding. Anal. Biochem., 72: 248-254.

Brown-Grant, K. (1961). Enlargement of salivary gland in mice treated with isopropyinoradrenaline. Nature, 191: 1076-1079.

Chisholm, D.M. \& Adi, M.M. (1995). Cell proliferation and apoptosis in isoprenaline-induced sialosis in the rat submandibular glands. Int. J. Exp. Path., 76: 263-269.

Chung, D.J., Wright, A. \& Clerch, L.B. (1998). The 3' untranslated region of manganese superoxide dismutase RNA contains a translational enhancer element. Biochemistry, 37: 16298-16306.

Dawes, C. (1984) Stimulus effects on protein and electrolyte concentrations in parotid saliva. J. Physiol. 346: 579-588.

Dringen, R. (2000). Metabolism and functions of glutathione in brain. Progress Neurobiol. 62: 649-671.

Edgar, W.M. (1992). Saliva: its secretion, composition and functions. Brit. Dent. J., 17: $305-312$.

Edgar, W.M., Higham, S.M., Manning, R.H. (1994). Saliva stimulation and caries prevention. Adv. Dent. Res., 8: 239-245. 
Esterbauer, H., Cheeseman, K.H. (1990). Determination of aldehydic lipid peroxidation products: Malonaldehyde and 4-hydroxy-nonenal. Method. Enzymol., 186: 407-421.

Flemming, N., Bilan, P.T. \& Graham, K.W. (1984). Effect of substance P on exocrine secretion by rat submandibular gland cells. J. Dent. Res., 63: 10221027.

Flemming, N., Bilan, P.T., Sliwinski-Lis, E. \& Carvalho, V. (1987). Muscarin, $\alpha 1-$ adrenergic and peptidergic agonists stimulate phosphoinositide hydrolysis and regulate mucin secretion in rat submandibular gland cells. Pfluger's Arch., 409: 416-421.

Floyd, R.A. (1990). The role of 8-hydroxydeoxyguanosine in carcinogenesis. Carcinogenesis, 11: 1447-50.

Fox, P.C., Busch, K.A. \& Baum, B.J. (1987). Subjectives reports of xerostomia and objectives measures of salivary gland performance J. Am. Dent Assoc. 115: 581-584.

Fridovich, I. (1974). Superoxide dismutases. Adv. Enzymol., 41: 35-97.

Fridovich, I. (1997). Superoxide anion radical $\left(\mathrm{O}_{2}{ }^{-}\right)$, superoxide dismutases, and related matters. J. Biol. Chem., 250: 18515-18517. 
Fridovich, I. (1995). Superoxide radicals and superoxide dismutases. Annu. Rev. Biochem., 64: 97-112.

Fujii, J., Nakata, T., Miyos'ıi, E., Ikeda, Y. \& Taniguchi, N. (1994). Induction of manganese superoxide dismutase mRNA by okadaic acid and protein synthesis inhibitors. Biochem. J., 301: 31-34.

Gaté, L., Paul, J., Nguyen Ba, G., Tew, K.D. \& Tapiero, H. (1999). Oxidative stress induced in pathologies: the role of antioxidants. Biomed \& Pharmacother,, 53: 169-180.

Garret, J.R. (1987). Innervation of salivary glands: neurohistological and functional aspects. The salivary System. Boca Raton: CRC Press, Inc, p. 6993.

Hachiya, M., Shimizu, S., Osawa, Y. \& Akashi, M. (1997). Endogenous production of tumor necrosis factor is required for manganese superoxide dismutase expression by irradiation in the monocytic cell line THP-1. Biochem. J., 328: 615-623.

Halliwell, B., Guterridge, J.M.C.(1999). Free radicals in biology and medicine, 3rd ed., Oxford University Press, N.Y.

Hatton, M.N., Loomis, R.E., Levine, M.J. \& Tabak, L.A. (1985). Mastigatory lubrification. The role of carbohydrate in the lubricating property of a salivary glycoprotein-albumin complex. Biochem. J., 230: 817. 
Hay, D.I. \& Moreno, E.C. (1989). Statherin and the acidic proline-rich proteins. in Clinical Chemistry of Human Saliva (Tenovuo, J. ed), Vol I, pp. 131-150, CRC Press, Boca Raton.

Hay, D.I., Smith, D.J., Schluckebier, S.K. \& Moreno, E.C. (1984). Relationship between concentration of human salivary statherin and inhibition of calcium phosphate precipitation in stimulated human parotid saliva. J. Dent. Res., 63: 857.

Hughes, P.J., Hughes, A.R., Putney, J.W. Jr. \& Shears, S.B. (1989). The regulation of the phosphorylation of inositol 1,3,4-trisphosphate in cell-free preparation and its relevance to the formation of inositol 1,3,4,6-tetrakisphosphate in agonist-stimulated rat parotid acinar cells. J. Biol. Chem. 264: 19871-19878.

Isoherranen, K., Peltola, V., Laurikainen, L., Punnonen, J., Laihia, M.A. \& Punnonen, K. (1997). Regulation of cooper/zinc and manganese superoxide dismutase by UVB irradiation, oxidative stress and cytokines. Photochem. Photobiol., 40: 288-293.

Johnson, D.A., Yeh, C.-K. \& Dodds, M.W.J. (2000). Effect of donor age on the concentration of histatins in human parotid and submandibular/sublingual saliva. Arch. Oral Biol., 45: 731-740. 
Jorge, A.O., Totti, M.A., de Almeide, O.P. \& Scully, C. (1993). Effect of sialadectomy on the carriage of Candida albicans in mouth of rats. J. Oral. Pathol. Med., 22: 138-140.

Kubo, T., Enokido, Y., Yamada, M., Oka, T., Uchiyama, Y. \& Hatanaka, H. (1996). Oxygen-induced apoptosis in PC12 cells with special reference to the role of Bcl-2. Brain. Res., 733: 175-183.

Laemmli, U.K. (1970). Cleavage of structural protein during the assembly of the head of bacteriophage T4. Nature, 227: 680-685.

Laniyonu, A.E., Sliwinki-Lis, E. \& Fleming, N. (1990). Muscarinic $M_{3}$ receptors are coupled to two signal transduction pathways in rat submandibular cells. Eur. J. Pharmacol., 188: 171-174.

Larsen, M.J., Jensen, A.F., Madsen, D.M. \& Pearce, E.I.F. (1999). Individual variation of $\mathrm{pH}$, buffer capacity, and concentrations of calcium and phosphate in unstimulated whole saliva. Arch. Oral Biol. 44: 111-117.

Larsson, B., Olivecrona, G. \& Ericson, T. (1996). Lipids in humans saliva. Arch. Oral Biol, 1: 105-110.

Lazowski, K.W., Mertz, P.M., Redmann, R.S., Ann, D.K., Kousvelari, E. (1992). Reciprocal expression of c-jun, proline-rich protein and amylase genes during rat parotid gland developmental. Differentiation, 51: 225-232. 
Levine, M.J., Reddy, M.S., Tabak, L.A., Loomis, R.E., Bergey, E.J., Jones, P.C., Cohen, R.E., Stinson, M.W. \& Al-Hashimi, I. (1987). Structural aspects of salivary glycoproteins. J. Dent. Res., 66: 436-441.

Levine, R.S., Weill, J.C. \& Elisson, S.A. (1969). The isolation and analysis of glycoprotein from parotid saliva. Biochim. Biophys. Acta, 188: 165.

Levine, R.S. (1989). Saliva: 1. The nature of saliva. Dent. Update., 16: 102-106.

Lüllmann, H., Mohr, K., Ziegler, K. \& Bieger, D. (1993). Color atlas of pharmacology. Thieme, Medical Publisher, Inc., N.Y. p. 102-103.

Lynch, D.P. (1994). Oral candidiasis: history, classification, and clinical presentation. Oral Surg. Oral Med. Oral Pathol., 78: 189-193.

Mandel, I.D. (1987). The functions of saliva. J. Dent. Res., 66 (Special issue): 623-647.

Mandel, I.D., Barr, C.E. \& Turgeon, L. (1992). Longitudinal study of parotid saliva in HIV-1 infection. J. Oral. Pathol. Med., 21: 209-213.

Martinez, J.R. (1987). Ion transport and water movement. J. Dent. Res,, 66: 638.

Martinez, J.R. (1990) Cellular mechanisms underlying the production of primary secretory fluid in salivary glands. Crit. Rev. Oral Biol., 1: 67-78. 
Matés, J.M. \& Sánchez-Jiménez, F.M. (2000). Role of reactive oxygen species in apoptosis: implications for cancer therapy. Int. J. Biochem. Cell Biol., 32: 157170.

McCord, J.M., Fridovich, I. (1968). The reduction of cytochrome c by milk xanthine oxidase. J. Biol. Chem., 243: 5753-5760.

Melvin, J.E., Kawaguchi, M., Baum, B.J., \& Turner, R.J. (1987). A muscarinic agonist-stimulated chloride efflux pathway is associated with fluid secretion in rat parotid acinar cells. Biochem. Biophys. Res. Commun. 145: 754-759.

Müller, J.M., Rupec, R.A., \& Baeuerle, P.A. (1997) Study of gene regulation by NFkB and AP-1 in response to reactive oxygen intermidiates. Methods, 11: 301

Murphy, M.E. \& Keher, J.P. (1989). Oxidation state of tissue thiol groups and content of protein carbonyl groups in chikens with inherited muscular dystrophy. Biochem. J., 260: 359-364.

Nakagawa, Y., Purushotham, K.R., Wang, P.L., Fischer, J.L., Dann, J.A., Schneyer, C.A. \& Humphreys-Beher, M.G. (1992) Alteration in the subcellular distribution of p21ras-GTPase activating protein in proliferating rat acinar cells. Biochem. Biophys. Res. Comm. 187, 1172-1179.

Nakahari, T., Ito, S., Yoshida, E.F. \& Imai, Y. (2000). Accumulation of cAMP evoked by acetylcholine stimulation in rat submandibular acinar cells: 
observation of exocytosis, fluid secretion and $\left[\mathrm{Ca}^{2+}\right] \mathrm{i}$. Exp. Physiol, 85: 159169.

Nederfors, T. \& Dahlöf, C. (1992). Effects of the b-adrenoceptor antagonists atenolol and propanolol on human whole saliva flow rate and composition. Arch. Oral Biol, 37: 579-584.

Nicolau, J. \& Sassaki, K.T. (1976). Metabolism of carbohydrate in the major salivary glands of rats. Arch. Oral. Biol., 21: 659-661.

Nicolau, J. \& Sassaki, K.T. (1983). Metabolism in vitro of the submandibular salivary glands (SMG) from mice injected with isoproterenol. Gen. Pharmacol., 14: 705-708.

Novi, A.M. \& Baserga, R. (1971). Association of hypertrophy and DNA synthesis in mouse salivary gland after chronic administration of isoproterenol. Am. J. Pathol., 62: 295-308

Oppenheim, F.G., Xu, T., McMillian, F.M., Levitz, S.M., Diamond, R.D., Offner, G.D. \& Troxler, R.F. (1988). Histatins, a novel family of histatin-rich proteins in human parotid secretion. Isolation, characterization, primary structure, and fungistatic effect on Candida albicans. J. Biol. Chem. 263: 7472-7477.

Peus, D., Meves, A., Vasa, R.A., Beyerle, A., O'Brien, T., \& Pittelkow, M.R. (1999). $\mathrm{H}_{2} \mathrm{O}_{2}$ is required for UVB-induced EGF receptor and downstream signalling pathway activation. Free Rad. Biol. Med. 27: 1197. 
Pollock, J.J., Denepitiya, L., Mackay, B.J. \& Iacono, V.J. (1984). Fungistatic and fungicidal activity of human parotid salivary histidine rich polypeptides on $\mathrm{C}$. albicans. Infect Immun., 44: 702-707.

Purushotham, K.R., Dunn, W.A. Jr, Schneyer, C.A. \& Humphreys-Beher, M.G. (1992). A novel mechanism for isoprenaline-stimulated proliferation of rat parotid acinar cells involving the epidermal growth factor receptor and cell surface galactosyltransferase. Biochem. J., 284: 767-776.

Quissell, D.O. (1993). Stimulus-exocytosis coupling mechanism in salivary gland cells. In: Dobrosielki-Vergona, K. Biology of the salivary glands. CRC Press, Boca Raton, Florida.

Quissell, D.O. \& Barzen, K.A. (1980) Secretory response of dispersed rat submandibular cells-II. Mucin secretion. Am. J. Physiol., 238: C99-C106.

Quissell, D.O., Barzen, K. \& Deisher, L.M. (1983a). Role of cyclic AMP-dependent protein kinase activation in regulating rat submandibular mucin secretion. Biochim. Biophys Acta., 762: 215-220.

Quissell, D.O. \& Deisher, L.M. (1992). Purification and partial characterization of analogous 26-kDa rat submandibular and parotid gland integral membrane phosphoproteins that may have a role in exocytosis. Archs Oral Biol., 37, 289295. 
Quissell, D.O., Deisher, L.M. \& Barzen, K. (1983b). Role of protein phosphorylation in regulating rat submandibular mucin secretion. Am. J. Physiol., 245: G44G53.

Quissell, D.O., Deisher, L.M. \& Barzen, K. (1985). The rate-determining step in cyclic AMP-mediated exocytosis in the rat parotid and submandibular glands appears to involve analogous 26-kDa Integral membrane phosphoprotein. Proc. Natl. Acad. Sci. USA, 82, 3237-3241.

Quissell, D.O., Deisher, L.M. \& Barzen, K. (1987). Role of protein phosphorylaion in rat salivary gland exocytosis. J. Dent. Res., 66: 596-598.

Quissell, D.O., Deisher, L.M. \& Barzen, K.A. et al. (1988). Subcellular distribution and activation of rat submandibular cAMP-dependent protein kinase following $\beta$-adrenergic receptor stimulation. Biochim. Biophys Acta., 969, 28-32.

Quissell, D.O., Deisher, L.M. \& Barzen, K.A. (1989). Activation and distribution of rat parotid CAMP-dependent protein kinase following $\beta$-adrenergic receptor stimulation in vitro. Archs Oral Biol., 34, 23-26.

Quissell, D.O. \& Redman, R.S. (1979). Functional characteristics of dispersed rat submandibular cells. Proc. Natl. Acad. Sci. USA, 76: 2789-2793.

Quissell, D.O., Redman, R.S., Barzen, K. \& McNutt, R.L. (1994). Effects of oxygen, insulin, and glucagon concentration on rat submandibular acini in serum-free primary culture. In Vitro Cell. Dev. Biol., 30A: 833-842. 
Quissell, D.O., Watson, E. \& Dowd, F.J. (1992). Signal transduction mechanisms involved in salivary gland regulated exocytosis. Crit. Rev. Oral Biol., 3: 83-107.

Rahnian, I \& MacNee, W. (2000). Regulation of redox glutathione levels and gene transcription in lung inflammtion: therapeutic approaches. Free Rad. Biol. Med., 28: 1405-1420.

Rathore, N., John, S., Kale, M. \& Bhatnagar, D. Lipid peroxidation and antioxidant enzymes in isoproterenol induced oxidative stress in rat tissues. (1998). Pharmocol. Res., 38: 297-303

Rayment SA, Liu B, Offner GD, Oppenheim FG, Troxler RF (2000). Immunoquantification of human salivary mucins MG1 and MG2 in stimulated whole saliva: factors influencing mucin levels. J Dent Res 79(10):1765-72

Reid, T.J. (1981). Structure and heme environment of beef liver catalase at $2,5 \AA$ resolution. Proc. Natl. Acad. Sci. USA, 78: 4767.

Rice-Evans, C.A., Diplock, A.T. \& Symons, M.C.R. (1991). Techniques in free radical research. In: Burdon, R.H. \& Van Knippenberg, P.H. [Eds.]. Laboratory techniques in biochemistry and molecular biology. Elsevier, Amsterdam.

Richter-Landsberg, C. \& Vollgraf, U. (1998). Mode of cell injury and death after hydrogen peroxide exposure in cultured oligodendroglia cells. Exp. Cell Res., 244: 218. 
Röhrdanz, E. \& Kahl, R. (1998). Alterations of antioxidant enzyme expression in response to hydrogen peroxide. Free Rad. Biol. Med., 24: 27-38.

Rollet, E., Grange, M.J., Elbim, C., Marquetty, C., Gougerot-Pocidalo, M.A. \& Pasquier, C. (1998). Hydroxyl radicals as a potencial intracellular mediator of polymorphonuclear neutrophil apoptosis. Free Rad. Biol. Med., 24: 563-572.

Rossie , K.M., Taylor, J., Beck, F.M., Hodgson, S.E. \& Blozis, G.G. (1987). Influence of radiation therapy on oral Candida albicans colonization: a quantitative assessment. Oral. Surg. Oral Med. Oral Pathol., 64: 698-701.

Schneyer, C.A. (1962). Salivary gland changes after isoproterenol induced enlargement. Am. J. Physiol., 203: 232-236.

Scully, C. (1986). Clinical and laboratory features, immunopathogenesis, and managment. Oral Med. Oral Surg. Oral Pathol., 62: 510-523.

Sies, H. (1993). Strategies of antioxidant defense. Eur. J. Biochem., 215: 213219.

Sies, H. (1999). Glutathione and its role in cellular functions. Free Rad. Biol. Med., 27: $916-921$.

Slomiany, B.L., Murty, V.L.N., Aono, M., Slomiany, A. \& Mandel, I.D. (1982). Lipid composition of human parotid and submandibular saliva from caries-resistant and caries-susceptible adults. Arch. Oral. Biol., 27: 803. 
Slomiany, B.L., Sengupta, S., Piotrowski, E., Lopez, R.A. \& Slomiany, A. (1992). Role of adrenergic and cholinergic mediators in salivary phospholipids secretion. Biochim. Biophys. Acta, 1124: 171-177.

Slomiany, B.L., Slomiany, A. \& Mandel, I.D. (1989) In Clinical Chemistry of Human Saliva (Tenovuo, J. ed), Vol II, pp. 121-145, CRC Press, Boca Raton.

Soltoff, S.P. \& Toker, A. (1995). Carbachol, substance P, and phorbol ester promote the tyrosine phosphorylation of protein kinase $C \delta$ in salivary gland epithelial cells. J. Biol. Chem., 270: 13490-13495.

Stadtman, E.R. (1990). Protein oxidation and aging. Science, 257: 1220-1224.

Stephens, L.C., King, G.K., Peters, L.J., Kian, K., Schultheiss, T.E. \& Jardine, J.H. (1986). Acute and late radiation injury in Rhesus monkey parotid glands. Am. J. Pathol., 124: 469-478.

Stephens, L.C., Schultheiss, T.E., Small, S.M., Ang, K.K. \& Peters, L.J. Response of parotid gland organ culture to radiation (1989). Radiat. Res., 120: 140-153.

Stojic, D. (1998). Carbachol-induced oxygen consumption in slices from developing rat submandibular and parotid glands. J. Dent. Res., 77: 16471653. 
Strickland, R.W., Tesar, J.T., Berne, B.H., Hobbs, B.R., Lewis, D.M. \& Welton., R.C. (1985). The frequency of sicca syndrome in an elderly female population. $J$. Rheumatol., 14: 766-771.

Tabak., L., Levine, M.J., Jain, N.K., Bryan, A.R., Cohen, R.E., Monte, L.D., Zawacki, S., Nancollas, G.H., Slomiany, A \& Slomiany, B.L. (1985). Adsorption of human salivary mucins to hydroxiapatite. Archs, Oral Biol., 30: 423-427.

Tabak, L., Levine, M.J., Mandel, I.D. \& Elisson, S.A. (1982). Role os salivary mucins in the protection of the oral cavity. J. Oral Pathol., 11: 1-17.

Takano, K., Malamud, D., Bennick, A., Oppenheim, F.G. \& Hand, A.R. (1993). Localization of salivary proteins in granules of human parotid and submandibular acinar cells. Crit. Rev. Oral Biol. Med. 4: 399-405.

Takuma, T. (1990). Evidence for the involvement of cAMP-dependent protein kinase in the exocytosis of amylase from parotid acinar cells. J. Biochem., 108: $99-102$.

Ten Cate, A.R. (1985). Desenvolvimento, estrutura e função. In Histologia Bucal. Ed. Guanabara.

Takuma, T. (1990). Evidence for the involvement of cAMP-dependent protein kinase in the exocytosis of amylase from parotid acinar cells. J. Biochem., 108: $99-102$. 
Towbin, H., Stachelin, T \& Gordon, J. (1979). Electropheretic transfer of proteins from polyacrylamide gels to nitrocellulose sheets: procedures and some applications. Proc. Natl. Acad. Sci. USA, 76: 4350-4354.

Turrens, J.F. \& Boveris, A. (1980). Generation of superoxide anion by the NADH dehydrogenase of bovine heart mitochondria. Biochem J., 191: 421-427.

Wang, X., Culotta, V.C. \& Klee, C.B. (1996). Superoxide dismutase protects calcineurin from inactivation. Nature, 383: 434-437.

Weldon, D., Poulsen, T.D., Mikkelsen, K.V. \& Ogilby, P.R. (1999). Singlet sigma: The "other" singlet oxigen in solution. Photochem. Photobiol, 70: 369-379.

Wiseman, H. \& Haliwell, B. (1996). Damage to DNA by reactive oxygen and nitrogen species: role in inflammatory disease and progression to cancer. Biochem. J., 313: 17-29.

Wong, P., Waggoner, D., Subramaniam, J.R., Tessarolo, L., Bartnikas, T.B., Culotta, V.C., Price, D.L., Rothstein, J. \& Gitlin, J.D. (2000). Copper chaperone for superoxide dismutase is essential to activate mammalian $\mathrm{Cu} / \mathrm{Zn}$ superoxide dismutase. Proc. Natl. Acad. Sci. USA, 97: 2886-2891.

Zeng, T., Yamamoto, H., Bowen, E., Broverman, R.L., Nguyen, K.T., HumphreysBeher, M.G. (1996). Cell cycle control in isoproterenol-induced murine salivary acinar cell proliferation. Comp. Biochem. Physiol, 115C: 271-279. 
Zhou J., Wright, P.S., Wong, E., Jessen, K., Morand, J.N. \& Carlson, D.M. (1997). Cyclic AMP regulation of mouse proline-rich protein gene expression: isoproterenol induction AP-1 transcription factors in parotid glands. Arch. Biochem. Biophys., 338: 97-103. 